Stratigraphy of the

Star Peak Group (Triassic)

and Overlying

Lower Mesozoic Rocks

Humboldt Range, Nevada

GEOLOGICAL SURVEY PROFESSIONAL PAPER 592

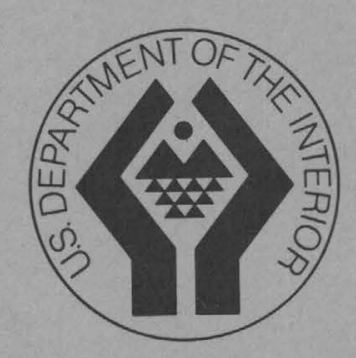



Stratigraphy of the

Star Peak Group (Triassic)

and Overlying

Lower Mesozoic Rocks

Humboldt Range, Nevada By N. J. SILBERLING and ROBERT E. WALLACE

GEOLOGICAL SURVEY PROFESSIONAL PAPER 592

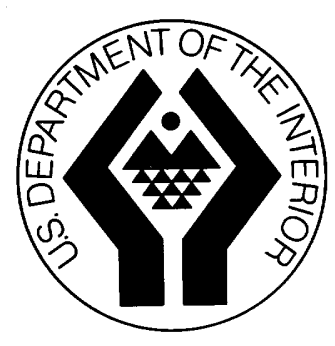

UNITED STATES GOVERNMENT PRINTING OFFICE, WASHINGTON : 1969 


\section{UNITED STATES DEPARTMENT OF THE INTERIOR \\ STEWART L. UDALL, Secretary \\ GEOLOGICAL SURVEY \\ William T. Pecora, Director}

Library of Congress catalog-card No. GS 68-262

For sale by the Superintendent of Documents, U.S. Government Printing Office

Washington, D.C. 20402 - Price $\$ 1.25$ (paper cover) 


\section{CONTENTS}

Abstract

Introduction

Fieldwork and geologic mapping

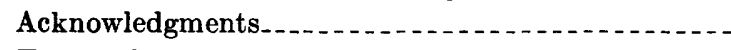

Terminology

Star Peak Group.

Prida Formation.

Lithologic description

Lower member

Middle member.

Upper member

Fossils and age.

Natchez Pass Formation.

Lithologic description.

Fossils and age.

Paleogeographic interpretation of the Star Peak Group.

Lateral variation at the base of the Star Peak Group
Page

1

2

6

6

6

6

8

10

10

13

13

15

20

21

24

25

25
Star Peak Group-Continued

Paleogeographic interpretation-Continued

Facies relation between the Prida and Natchez

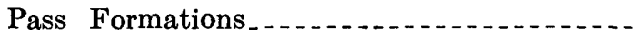

Relationship between volcanic and carbonate rocks in the Natchez Pass Formation......

Regional relations of the upper member of the Natchez Pass Formation..................

Grass Valley Formation. Lithologic description. Age

Paleogeographic interpretation. . . . . .

Dun Glen Formation

Lithologic description.

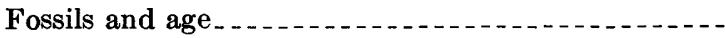

Post-Dun Glen lower Mesozoic strata in the Pershing district. . .

Lower unit._.

Upper unit.

References

Index.
Page

30

31

31

34

36

40

41

42

44

44

46

47

49

\section{ILLUSTRATIONS}

1. Fence diagram showing the reconstructed section of the lower part of the Prida Formation along the east side of the Humboldt Range between Congress and Star Canyons, Nev . .

2. Fence diagram showing the reconstructed section of the Star Peak Group along the length of the Humboldt Range, Nev .

Figure 1. Index map showing location of the Humboldt Range

2. Diagram showing succession of lower Mesozoic rock units in the Humboldt Range.

3. Diagram showing time-stratigraphic correlation and lateral variations in the age of the lower Mesozoic rock units in the Humboldt Range.

4-8. Photographs showing:

4. East flank of Star Peak

5. Talus characteristic of the brown calcareous sandstone unit; lower member of the Prida Formation --

6. Weathered block composed partly of metavolcanic rock and partly of impure dolomite; lower member of the Prida Formation.

7. Outcrop of dark laminated dolomite; upper member of the Prida Formation...

8. Carbonate rocks from the upper member of the Prida Formation on Fossil Hill

9. Isopach map of pre-upper Anisian strata at the base of the Star Peak Group

10. Very thin and thin-bedded impure sandstone of the Grass Valley Formation

11. Linguoid ripple marks on the top surface of an impure sandstone bed in the Grass Valley Formation.....

12. Sedimentary structures on the bottom surfaces of sandstone slabs from the upper part of the Grass Valley Formation

13. Sedimentary structures of a single slab of thin-bedded impure sandstone from the Grass Valley Formation

14. Diagrammatic comparison of the thickness, composition, and paleocurrent directions of the Grass Valley

Formation in the Humboldt Range and nearby ranges to the east

15. Photograph showing carbonate breccia and conglomerate from Upper Triassic rocks of the Pershing district

\section{TABLE}




\title{
STRATIGRAPHY OF THE STAR PEAK GROUP (TRIASSIG) AND OVERLYING LOWER MESOZOIC ROCKS, HUMBOLDT RANGE, NEVADA
}

\author{
By N. J. Silberling and Robert E. Wallace
}

\section{ABSTRACT}

The Star Peak Group and other, still younger, lower Mesozoic rocks of the "Winnemucca sequence" of Silberling and Roberts form roughly half the bedrock exposures in the Humboldt Range, which occupies parts of the Imlay, Unionville, and Buffalo Mountain quadrangles in northwestern Nevada. These strata, aggregating more than 10,000 feet in thickness, are largely marine sedimentary rocks that overlie with subtle angular unconformity the predominantly volcanic Koipato Group of Permian to earliest Triassic age. Exposures of the Star Peak Group roughly encircle the central part of the range and are most extensive at its north and south ends. The Star Peak Group, comprising the Prida and Natchez Pass Formations, is characterized by calcareous rocks whose composition contrasts sharply wth that of the overlying formations, which are composed mainly of fine-grained terrigenous clastic rocks.

The Prida Formation, the lower formation of the Star Peak Group, is divided into three informal members. Its lower member is lithologically heterogenous and includes a variety of calcareous terrigenous clastic rocks and impure carbonate rocks above a basal clastic unit of noncalcareous sandstone and conglomerate. Lateral lithologic changes within the lower member and variation in its thickness from a few tens of feet to several hundred feet reflect the original slope and topographic irregularity of the eroded surface of the underlying rocks of the Koipato Group. In the northern part of the Humboldt Range, much of the lower Prida is locally cut out against two prominent basement highs that coincide in location with intrusive parts of the Koipato rolcanic pile and with the principal silver deposits in the Star Peak rocks. Elsewhere in the northern part of the range, where the lower member of the Prida is thickest and was first deposited, the lower member includes at least two successive ammonite faunas of Spathian (latest Early Triassic) age.

The middle member of the Prida similarly ranges in thickness, locally attaining a maximum of 400 feet in the northern part of the range, but it is lithologically uniform and everywhere consists of gray, commonly highly fossiliferous limestone interbedded with calcareous shale and siltstone. It preserves a uniquely complete sequence of ammonite faunas representative of early, middle, and late Anisian (early Middle Triassic) time.

The upper member of the Prida shows pronounced lateral variation in its thickness and age, progressively thickening from 100 feet in the southern part of the range, where it is wholly Ladinian (late Middle Triassic) in age, to 2,000 feet or more in the northwestern part of the range, where it ranges from early Ladinian to early Karnian (earliest Late Triassic) in age. The upper Prida is composed of evenly parted dark cherty laminated limestone (or, more rarely, dolomite) having some interbedded units of massive organic-detrital carbonate rocks. Fossils are scarce and except for sponge spicules, exclusively of planktonic invertebrates. Lateral changes in the thickness and age of the upper
Prida are compensated for by changes in the thickness and age of the massive organic-detrital carbonate rocks that form the lower part of the overlying Natchez Pass Formation. The upper Prida and part of the lower Natchez Pass are therefore interpreted as interfingering facies of one another, the upper Prida being the deposit that accumulated farther from shore and in deeper water.

Within the Natchez Pass Formation, which forms the upper formation of the Star Peak Group, two members are recognized throughout most of the Humboldt Range. The lower member consists mainly of massive thick and very thick bedded carbonate rocks except in the southern part of the range, where roughly half of its 1,500-foot thickness is made up of mafic volcanic rocks. Farther north in the range, where the lower Natchez Pass is largely supplanted by the upper Prida, the thickness of the lower Natchez Pass is as little as 400 feet.

The upper member of the Natchez Pass is about 1,000 feet thick wherever recognized in the Humboldt Range. In most of the range, brown-weathering impure silty limestone forms its lower part and abruptly, and perhaps disconformably, overlies the lower member. These impure limestones grade upward into an approximately equal thickness of massive thick-bedded relatively pure carbonate rock resembling that of the lower member.

Although these two members cannot be recognized among the structurally deformed carbonate rocks of the Natchez Pass at the northeastern tip of the range, about $\mathbf{4 0 0}$ feet of interbedded chert conglomerate, sandstone, and calcareous siltstone in the middle part of the section there may be a coarse clastic equivalent of the impure limestone that forms the lower part of the upper member farther south.

In the southern part of the range, the Natchez Pass contains fossils of probable early Karnian (earliest Late Triassic) age in its middle part and probably includes beds ranging from late Ladinian to late Karnian in age. Farther north, where the lower Natchez Pass is thinnest, the formation may be entirely late Karnian in age.

Overlying the Star Peak Group at both ends of the Humboldt Range is the Grass Valley Formation, whose estimated thickness is a few thousand feet. Dark chlorite-bearing noncalcareous pelitic rocks and sandstone characterize the Grass Valley, which is unfossiliferous except for occasional plant remains. Sandstone interbedded with the pelitic rocks accounts for about one-third of the total thickness and is of two generally different kinds. The more common kind is dark thin-bedded very fine grained micaceous sandstone that occurs in laterally discontinuous units throughont the section. Bedding surfaces, both in the Humboldt Range and to the northeast in the East Range, commonly bear linguoid ripple marks and other sedimentary features that indicate uniform northwest-trending current directions. Less common than the impure sandstone is clean medium-grained sandstone. It occurs in laterally persistent units, generally a few tens of feet thick, and may represent beach and 
bar deposits. The Grass Valley is similar in composition to much of the upper part of the lower Mesozoic section in northwestern Nevada, in which rapidly deposited fine-grained terrigenous clastic sedimentary rocks predominate. Regional facies changes, composition, sedimentary structures, and stratigraphic position between shallow-water marine carbonate rocks suggest that the Grass Valley is part of a prograding deltaic complex related to major river drainage that flowed into northwestern Nevada from the east.

The upper part of the Grass Valley, together with younger rocks, is preserved only in the Pershing mining district at the southern tip of the Humboldt Range. There, the uppermost several hundred feet of the formation is repeated by large-scale overturned folds. Unlike most of the Grass Valley, this upper part weathers orange and red, is partly calcareous, and locally contains marine fossils, including ammonites of early middle Norian (late Late Triassic) age.

The Grass Valley grades upward into carbonate rocks of the Dun Glen Formation. The Dun Glen ranges in thickness from several tens of feet to a few hundred feet in the Pershing district, but is considerably thicker in mountain ranges farther east in northwestern Nevada. Most of the Dun Glen is well-bedded massive limestone that locally contains a large and diverse assemblage of shallow-water marine invertebrates and calcareous algae. Where the formation is thickest, its upper part consists of intraclastic limestone or dolomitic sedimentary breccia.

The post-Dun Glen lower Mesozoic strata in the Pershing district are divided into two informal map units, the lower of which consists mainly of orange- and red-weathering partly calcareous pelitic rocks, siltstone, and sandstone resembling the uppermost Grass Valley Formation in the same area. Owing to structural complications, the thickness of the lower unit of post-Dun Glen strata is uncertain, but it is thought to be about 2,000 feet. At one place a large ammonite fauna of late middle Norian age was obtained from near the base of the lower unit. In the part of the Pershing district where the underlying Dun Glen Formation is relatively thin, a conspicuous unit of dolomite conglomerate up to 100 feet thick occurs a few hundred feet above the base of the lower unit of post-Dun Glen strata. The mercury deposits of the Pershing district are largely restricted to this dolomite conglomerate and to the limestone and dolomite sedimentary breccia that forms the upper part of the thick Dun Glen sections in other parts of the district.

The upper unit of post-Dun Glen strata is lithologically heterogenous and includes a variety of calcareous siltstones and sandstones, limestones, and pelitic rocks having an aggregate exposed thickness of more than 1,000 feet. Upper Norian (upper Upper Triassic) ammonites and the pelecypod Monotis subcircularis occur at several places in its lower part. Ammonites indicative of both the lower and the upper parts of the Lower Jurassic have also been found in isolated exposures of strata that are included in the upper unit and are the youngest preTertiary strata in the Humboldt Range.

\section{INTRODUCTION}

The Star Peak Group and the other lower Mesozoic strata that overlie it form the "Winnemucca sequence" of Silberling and Roberts (1962), one of several distinct sequences of largely marine lower Mesozoic rocks that characterize different parts of northwestern $\mathrm{Ne}$ vada. In the Humboldt Range, whose geographic setting is shown in figure 1, rocks of the "Winnemucca sequence" aggregate more than 10,000 feet in thickness and, together with the underlying dominantly volcanic Koipato Group, form by far the largest part of the bedrock exposures.

The succession of lower Mesozoic rock units and their variations in thickness from one end of the range to the other are illustrated diagrammatically in figure 2. The age relations of these rock units are shown in figure 3.

These lower Mesozoic strata of the "Winnemucca sequence" roughly encircle the central part of the Humboldt Range and delineate its major structure, which is a large-scale much-deformed anticlinal fold whose axis strikes somewhat northeast of the general north trend of the range. Calcareous rocks of the Star Peak Groupthat is, the lower part of the "Winnemucca sequence"border the range on either side and dip away from the older rocks of the Koipato Group that are in the anticlinal core of the range. Toward either end of the range, strata of the "Winnemucca sequence" are more widely and completely exposed. In the northern part of the range, they form the stucturally complex and partly overturned west limb of the major anticlinal structure, and at the southern end of the range they wrap around the southward-plunging axis of this fold and are involved in northwest-trending folds that apparently truncate the major northeast-trending anticline. The higher parts of the "Winnemucca sequence" that overlie the Star Peak Group at the north end of the Humboldt Range are represented by the Grass Valley Formation; at the south end of the range they include the Grass Valley and Dun Glen Formations and still younger, unnamed beds of latest Triassic and Early Jurassic age. As elsewhere, these higher parts of the "Winnemucca sequence," though partly calcareous, are composed mainly of fine-grained terrigenous clastic rocks.

The Humboldt Range affords an unusually good opportunity to study the "Winnemucca sequence"-particularly its lower part-because these rocks are contained in a single continuously exposed structural block nearly 40 miles long. Probably nowhere else in northwestern Nevada can lateral changes among the scattered exposures of lower Mesozoic rocks be studied over so great a distance without risk of overlooking large-scale structural rearrangement. Another notable feature of the "Winnemucca sequence" in the Humboldt Range is its generally more marine character in comparison with the related rocks in the ranges to the east. Thus, marine faunas found in the Humboldt Range provide relatively precise age assignments for several different parts of the "Winnemucca sequence" whose ages elsewhere have been uncertain. 


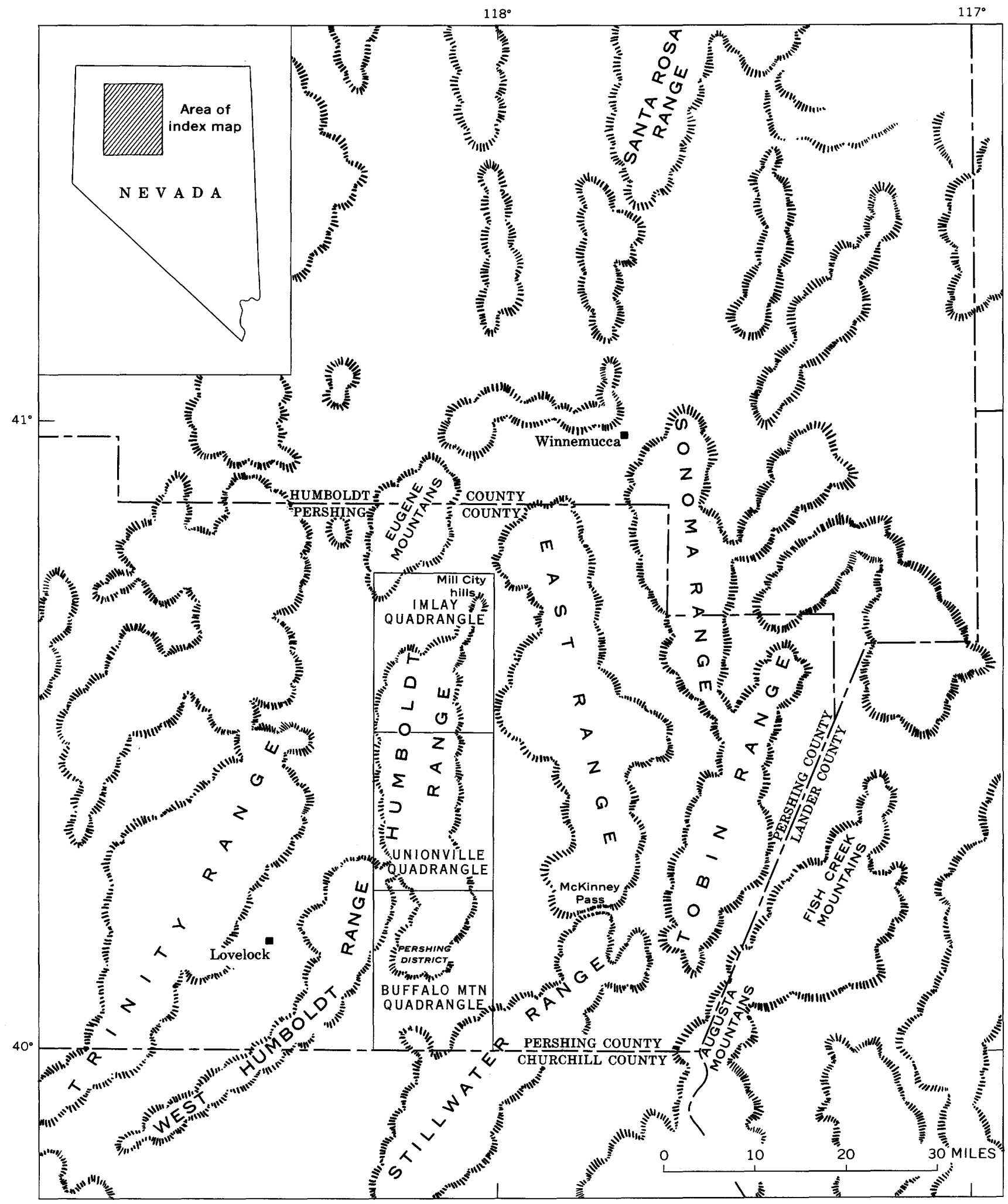

FIGURE 1.-Location of the Humboldt Range and the Imlay, Unionville, and Buffalo Mountain 1:62,500 quadrangles in relation to other nearby geographic features referred to in text. 


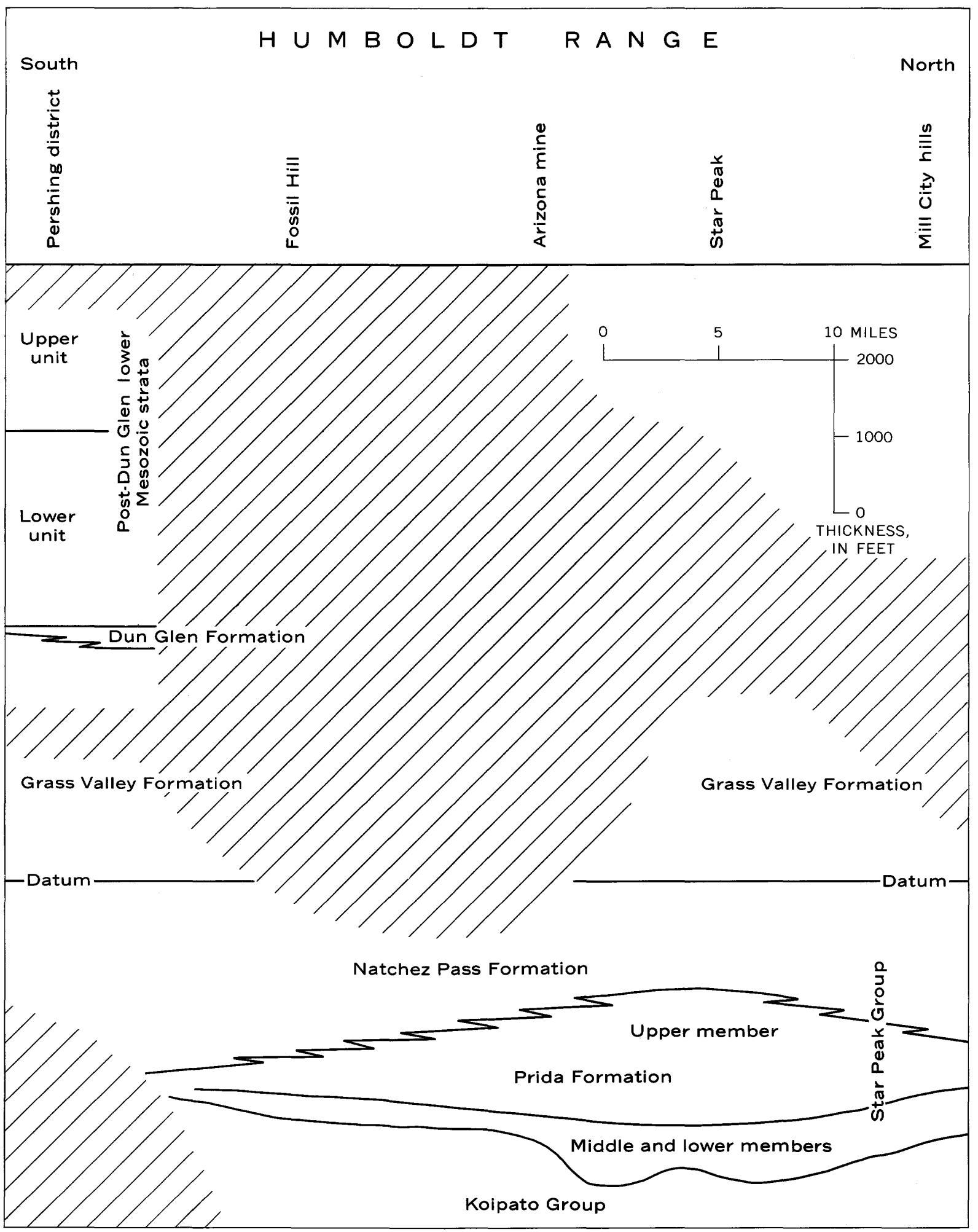

Figure 2.-Succession of lower Mesozoic rock units in the Humboldt Range showing the thickness and representation of the units from the south end of the range to the north end. Diagonal ruling indicates parts of the rock record that have been removed by erosion or that are obscured by younger deposits or by structural complications. 


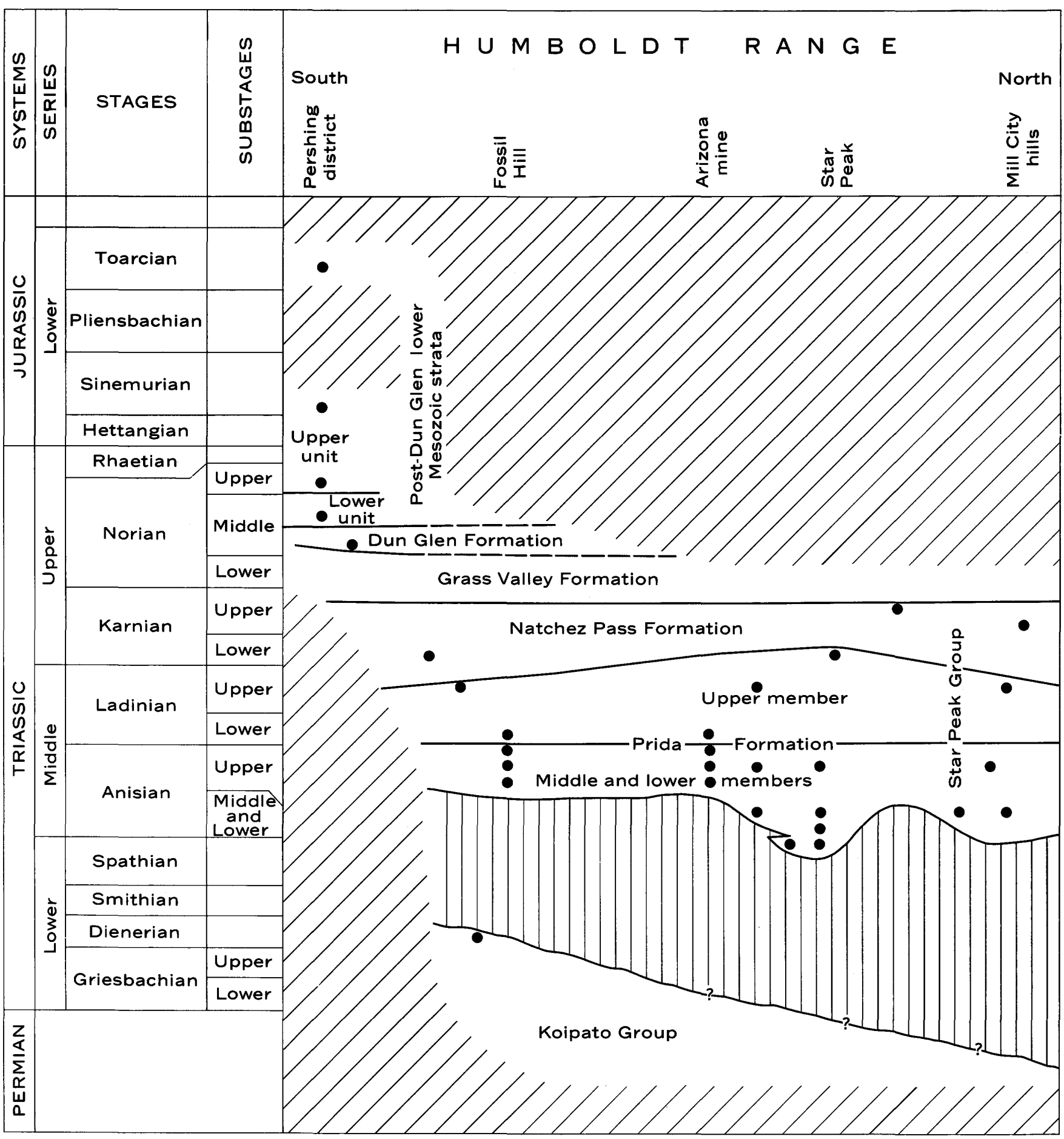

Figure 3.-Time-stratigraphic correlation and lateral variations in the age of the lower Mesozoic rock units in the Humboldt Range. Solid dots represent the occurrence of age-diagnostic fossils. Vertical ruling indicates stratigraphic hiatus; diagonal ruling, lack of data. 
STRATIGRAPHY OF THE LOWER MESOZOIC ROCKS, HUMBOLDT RANGE, NEVADA

FIELDWORK AND GEOLOGIC MAPPING

The present report stems from two larger programs, one concerned with the geology and mineral deposits of the Buffalo Mountain, Unionville, and Imlay 1:62,500 quadrangles, and a second concerned with the Triassic System in North America. Fieldwork in the Humboldt Range was done by the writers and D. B. Tatlock largely during the summers of $1956-59$ but also during subsequent shorter visits to the area.

The part of the Humboldt Range that lies within the Imlay quadrangle, including the type locality of the Star Peak Group, was mapped geologically on field sheets at a scale of $1: 24,000$. Those areas where rocks of the "Winnemucca sequence" crop out in the northeastern and southeastern parts of the range within the Unionville quadrangle were mapped on field sheets at $1: 12,000$; elsewhere in this quadrangle, mapping was at a scale of $1: 48,000$. Likewise, the areas of "Winnemucca sequence" outcrop in the southeastern part of the range within the Buffalo Mountain quadrangle, as well as parts of the Pershing district within this quadrangle, were mapped in the field at 1:12,000; the other parts of the Buffalo Mountain quadrangle were mapped at $1: 48,000$.

This mapping, which documents the present stratigraphic study, is incorporated in the separately published geologic quadrangle map of the Imlay quadrangle (Silberling and Wallace, 1967) and in the yet unpublished Unionville and Buffalo Mountain quadrangle maps being prepared by R. E. Wallace, N. J. Silberling, and D. B. Tatlock. The geologic quadrangle maps of the Buffalo Mountain and Unionville quadrangles are to supersede the preliminary geologic maps of these areas published previously (Wallace and others, 1959, $1960)$.

Most of the stratigraphic thicknesses given in the descriptions of these lower Mesozoic strata are based on the geologic-map relations of the strata. For the most part, detailed measured sections of the rocks are meaningless, as the units are thick, monotonously uniform and lacking marker horizons, and locally poorly exposed and structurally complex.

\section{ACKNOWLEDGMENTS}

Previous geologic research that touched on some aspect of the "Winnemucca sequence" in the Humboldt Range began with the pioneer studies of the 40th Parallel Survey (Hague and Emmons, 1877; King, 1878) and included studies by Hyatt and Smith (1905), Ransome (1909), Smith (1914) and Knopf (1924). The report by Cameron (1939) concerning the geology of a large area in the northeastern part of the range was especially helpful.

The Humboldt Range is one of the few stratigraphically significant areas that escaped rigorous study by Dr. S. W. Muller, of Stanford University and the U.S. Geological Survey, during his researches on the lower Mesozoic of northwestern Nevada. Nevertheless, Professor Muller gave considerable aid-based on his reconnaissance in various parts of the range-in directing the writers to localities of critical geologic and paleontologic interest.

Dr. Stanisław Dzułynski, of the Polish Academy of Sciences, visited various exposures of the Grass Valley Formation and related rocks in the vicinity of the Humboldt Range during 1958 in company with Silberling. His help in interpreting the depositional history of these rocks is gratefully acknowledged.

Dr. E. T. Tozer, of the Geological Survey of Canada, provided invaluable advice on the identification and age assignment of the Triassic molluscan faunas at various times during the course of this study and during a visit to the area in 1964.

\section{TERMINOLOGY}

The conventions of terminology used in the following stratigraphic descriptions are those proposed by Wentworth (1922) for the grain size of clastic sedimentary rocks, by Goddard and others (1948) for rock colors, and by Ingram (1954) for the thickness of stratification and parting units in sedimentary rocks. The term "massive" is applied to rocks characterized by relatively thick beds that lack apparent internal compositional variations or structures.

Most of the lower Mesozoic carbonate rocks of the Humboldt Range have undergone some degree of recrystallization, but insofar as possible the terminology used for limestones follows the classification of Folk $(1959,1962)$, and the crystallinity of carbonate rocks is expressed according to the scheme recommended by Folk (1962).

All U.S. Geological Survey Mesozoic fossil localities in the Humboldt Range that are cited by number in the text are either plotted on the geologic quadrangle maps or related on plate 1 to plotted localities.

\section{STAR PEAK GROUP}

The Star Peak Group, for which Star Peak in the northern Humboldt Range is the type locality, comprises the predominantly calcareous Prida and Natchez Pass Formations, whose typical exposures are in the East Range. In the Humboldt Range these formations are locally nearly 4,000 feet in combined thickness and range from latest Early Triassic to medial Late Trias- 
sic in age. The Prida Formation rests unconformably on the Koipato Group, and its lower part consists of impure carbonate rocks and calcareous clastic rocks whose composition and thickness vary from place to place. Laminated cherty limestone and dolomite form most of the upper part of the Prida, whose thickness ranges greatly in the Humboldt Range and varies inversely with the thickness of the lower part of the overlying Natchez Pass Formation. Massive thick-bedded organic-detrital carbonate rocks characterize the Natchez Pass, but generally subordinate amounts of volcanic rocks, terrigenous clastic rocks, and impure limestone are also present, particularly in its middle part. Mafic volcanic rocks and related dikes occur at various levels within the Star Peak Group, but they add little to its thickness except in the southwestern part of the range, where volcanic flows, tuffs, and breccias constitute about half of the Natchez Pass Formation.

The Star Peak was originally described in the reports of the 40th parallel survey by King (1878, p. 269, 273277) and Hague and Emmons (1877, p. 723-727) as a group consisting of an alternating succession of three thick limestone units and three equally thick quartzite units. These were thought to represent the upper part of the Triassic, to total nearly 10,000 feet in thickness, and to conformably overlie the Koipato Group, which was described as a thick succession of argillites, quartzites, and their metamorphic equivalents. The lowest unit of the Star Peak was described as the limestone resting on the Koipato near the mouth of Star Canyon on the east side of the range. Successively higher units were recognized westward up to the crest of the range, and the highest quartzite unit of the Star Peak was said to occupy the upper part of Humboldt Canyon on the west side of the range. This quartzite unit, in turn, was thought to be conformably overlain toward the mouth of Humboldt Canyon by a limestone unit and a slate unit, both of which were dated as Jurassic.

The section of the Star Peak as described by King and Hague and Emmons was briefly commented upon by Hyatt and Smith (1905, p. 21), who pointed out that unrecognized repetition by faulting had resulted in an exaggeration of the thickness of the section. Ransome (1909, p. 32) noted that considerable revision of the original description was needed and was the first to recognize the dominantly volcanic character of both the Koipato and the "quartzite" units included in the typical section of the Star Peak.

The Star Peak Formation was revised by Cameron $(1939$, p. 580-583) on the basis of reconnaissance geologic mapping in the northeastern part of the Humboldt Range. Cameron demonstrated that the "quartzite" units originally included in the Star Peak represent Koipato volcanic rocks repeated by strike faulting, and the Star Peak was redefined as comprising the mainly calcareous Middle and Upper Triassic strata overlying the Koipato. Recognizing that the upper limit of the Star Peak is not exposed in the area studied by him, Cameron selected as the most complete sequence the limestones exposed on the east face of Star Peak from the outcrops of the Koipato in American Basin up to the summit (fig. 4). This sequence was described as a continuous section formed by three successive limestone members with a total exposed thickness of about 3,500 feet, but subsequent mapping with the advantage of more stratigraphic and structural control from surrounding areas showed that these limestones on the east side of Star Peak are both broken by faults and partly repeated by a large fold. In fact, in the northern part of the Humboldt Range no continuous section of the carbonate rocks included here in the Star Peak Group is exposed, nor has a reliable composite section of the entire group been pieced together, owing to the scarcity of marker beds within the thick section and to the complex structure.

The Star Peak "group" of King or "formation" of Cameron in its type area is thus not amenable to revision in terms of a standard section; fortunately, the need for adequately defined units of formation rank in this part of the section is fulfilled by the Prida and Natchez Pass Formations established by Muller, Ferguson, and Roberts (1951) for exposures in the nearby ranges to the east. These formations are readily recognized in the Humboldt Range, though some notable lateral variations exist. As the various limestone exposures originally included in the Star Peak are all assignable to parts of the Prida or Natchez Pass Formations, the name Star Peak is retained in this paper for a group embracing these two formations. This is a natural grouping and emphasizes the contrast between these predominantly calcareous formations and the overlying lower Mesozoic formations, which are composed mainly of fine-grained terrigenous clastic rocks.

In the Humboldt Range, as in the ranges farther east, the Star Peak Group is conformably overlain by the Grass Valley Formation composed of metapelitic rocks and sandstones of medial Late Triassic age. The socalled Jurassic limestone that in the interpretation of King (1878, p. 294-295) was supposed to overlie the highest "quartzite" unit of the "Star Peak Triassic" in Humboldt Canyon is, like the limestone units within King's Star Peak "group," a structural mixture of different parts of the Prida and Natchez Pass Formations. The "Jurassic slates," which in turn were thought to overlie this so-called Jurassic limestone unit, belong to 


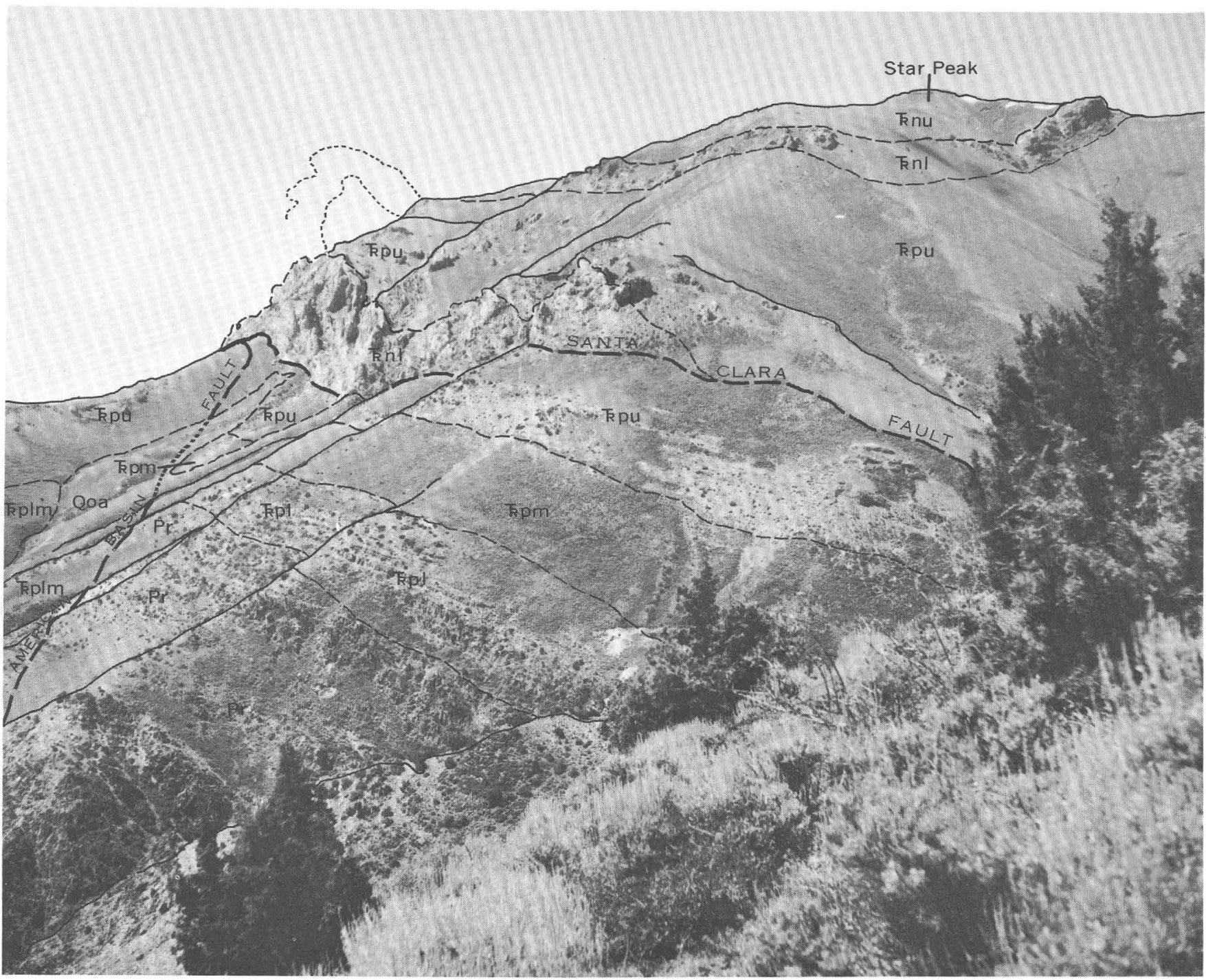

FIGURe 4.-East flank of Star Peak. Rocks exposed form part of the Star Peak Group as originally described by King (1878) and were subsequently used by Cameron (1939) as the basis for redefinition of the group. Rock units as labeled are: Rochester Rhyolite (Pr); Prida Formation, comprising the lower member ( $k p \mid)$ and middle member ( $k p m)$, or the undifferentiated lower and middle members $(\mathrm{kp} / \mathrm{m})$, and the upper member ( $\mathrm{kpu})$; Natchez Pass Formation, including the lower member ( $\mathrm{knl}$ ) and upper member" (Knu); and Quaternary older alluvial deposits (Qoa).

the Grass Valley Formation. Thus the rocks upon which King (1878, p. 269) based his statement that in the Humboldt Range "the Trias and the Jura are perfectly conformable" actually have no bearing on the TriassicJurassic boundary.

\section{PRIDA FORMATION}

The Prida Formation as established by Muller, Ferguson, and Roberts (1951) has the northeastern East Range as its type locality. The somewhat deformed and laterally variable section in the East Range has not been described in detail, but in general the Prida at its type locality includes (1) a lower unit that consists of 10-50 feet of basal sandstone and conglomerate, derived from the underlying Koipato Formation, overlain by $50-100$ feet of brown-weathering massive silty and sandy dolomite; (2) a middle unit of about 150 feet of calcareous shale and siltstone with interbeds of gray limestone; and (3) an upper unit of about 100 feet of regularly bedded dark-gray cherty limestone transitional into the overlying mostly massive dolomite and limestone of the Natchez Pass Formation.

In the Humboldt Range, exposures of the Prida Formation almost encircle the rocks of the Koipato Group that occupy the core of the broad anticlinal fold in the central part of the range. The Prida crops out intermittently along the southeast flank of the range from American Canyon south to Fisher Canyon; from there 
it swings westward, crosses Black Ridge in a narrow outcrop band, and then continues from the north end of Packard Flat northward along the west flank of the range. North of the latitude of Rocky Canyon, in the northern part of the Unionville quadrangle and in the Imlay quadrangle, the Prida is widely exposed in the higher parts of the range, where it forms part of the structurally complex northwestern limb of the same large-scale anticlinal fold.

In the southern part of the Humboldt Range-for example, on the east slope of Black Ridge within the Buffalo Mountain quadrangle - the lithologic succession and thickness of the Prida Formation are about the same as in its type area in the northeastern East Range. Though not everywhere shown on the geologic map, three informal subdivisions, termed the lower, middle, and upper members can be recognized; these correspond to the three units given for the type locality. In this part of the Humboldt Range, as in the northern East Range, the Prida is wholly Middle Triassic, ranging from late Anisian to Ladinian in age. (See fig. 3.)

Farther north in the Humboldt Range, the thickness of the Prida increases markedly and progressively, attaining a maximum of over 2,500 feet in the northwestern part of the range. Although the same three members can be recognized, the gross aspect of the formation differs considerably from that farther south in the Humboldt Range or in the East Range owing to pronounced differences in the relative thickness of the different members. Several hundred feet of this increase in thickness within the Humboldt Range results from lateral variations in the lower and middle members; these variations reflect the configuration of the preexisting erosional surface of the underlying Koipato Group. Locally, in the northern part of the range, deposition of the Prida began as early as the Spathian (latest Early Triassic), and the lower and middle members are each as much as 400 feet thick. Most of the increase in thickness of the formation, however, results from thickening of the upper member at the expense of the overlying Natchez Pass Formation. (See fig. 2.) The thick sequence of dark laminated cherty limestone that forms the upper member of the Prida includes beds as young as earliest Karnian (earliest Late Triassic) in the northwestern part of the range and is interpreted to be in large part a relatively offshore, deeper water facies of the massive carbonate rocks that form the lower part of the Natchez Pass Formation and have their greatest thickness in the southern part of the range.

The Prida Formation in the Humboldt Range, like that in the nearby ranges to the east (Muller and others, 1951; Ferguson and others, 1951), rests unconformably on the Koipato Group. Angular discordance is shown by gradual truncation of units within the Koipato beneath the unconformity, but the amount of discordance is too small for measurement in any one exposure. At many places in the range, the basal beds of the Prida are conglomerate and sandstone composed of detritus from the underlying Koipato, and they are indicative of a period of erosion preceding deposition of the Star Peak Group as noted by Wheeler (1939, p. 106-107) and Cameron $(1939$, p. 580). Starting with King (1878, p. 269), early workers were influenced by the lack of obvious discordance between the Koipato and Star Peak and were misled by the inclusion of fault slivers of Koipato rocks in the typical Star Peak section. Consequently, they regarded the two sequences as conformable and assigned the Koipato to the lower part of the Triassic. The strong argument by Knopf $(1924$, p. 30) for conformity between, and even contemporaneity of the limestones of the Star Peak and volcanic rocks of the underlying Koipato was based on exposures on the west flank of Black Ridge, where the nature of the contact between these groups is indeed deceiving. Here, the Weaver Rhyolite at the top of the Koipato includes a thick clastic unit that is unique in containing a few beds of limestone; the highest unit of the Weaver is a mixture of rhyolite felsite and clastic rocks indistinguishable from the sheared basal clastics of the Prida; the section of the Prida is the thinnest in the range; and most of the overlying Natchez Pass Formation is composed of volcanic flows, breccias, and tuffs rather than the carbonate rock more characteristic of the formation. All of these units, however, can be traced northeastward to the east side of the range, where the unconformable relation between the Prida Formation and the underlying Weaver Rhyolite is more apparent. Beneath the Prida near the mouth of Fisher Canyon the highest unit of the Weaver is a rhyolite felsite which is successively underlain by a clastic unit, another felsite unit, and another clastic unit. On the north side of Troy Canyon, 2 miles farther north, the upper felsite unit is absent, and the Prida rests on the underlying upper clastic unit. Between Troy and South American Canyons, this upper clastic unit in turn thins northward beneath the unconformity until it feathers out, and the Prida ultimately rests on the lower felsite unit. This progressive truncation of the Koipato agrees with the general trend, first observed by Cameron $(1939$, p. 579), for the Star Peak Group to progressively overlie stratigraphically lower parts of the Koipato toward the north end of the range.

Only several hundred feet of the Rochester Rhyolite separates the Prida Formation from greenstones assigned to the lowest formation of the Koipato Group, the Limerick Greenstone, in the northeastern part of the range, whereas a thick section of Rochester Rhyo- 
lite underlies the Prida in the central part of the range; at the south end of the range, both the Rochester and the overlying Weaver Rhyolite, which total several thousand feet, intervene between the Limerick Greenstone and the base of the Star Peak Group. Considerable erosion of the Koipato Group in the northern Humboldt Range prior to deposition of the Prida Formation is further suggested by exposures in and around Humboldt Canyon, where the Prida rests both on the Rochester Rhyolite and on sills of rhyolite prophyry within the Rochester that are interpreted as feeder dikes for higher parts of the Koipato Group such as the Weaver Rhyolite at the south end of the range. The greater depth to which the Koipato in the northern part of the range was eroded prior to Star Peak deposition, together with the general north to south transgression of the Star Peak over the eroded surface of the Koipato, results in a somewhat different stratigraphic hiatus at the unconformity between the Star Peak and Koipato Groups in different parts of the range. To the north, the hiatus represents latest Permian to late Early Triassic time, but to the south it represents early Early Triassic to early Middle Triassic time.

\section{LITHOLOGIC DESCRIPTION LOWER MEMBER}

The lower member of the Prida Formation shows marked lateral variations in thickness, composition, and age within the Humboldt Range. (See pl. 2.) These variations reflect a general southward transgression of the Star Peak seas across the eroded surface of the Koipato Group, upon which local topographic highs stood as islands or peninsulas during the initial phases of Prida deposition.

Though lithologically hetergeneous, the lower member consists mainly of calcareous and dolomitic siltstone and sandstone or silty and sandy limestone and dolomite, the relative proportions varying from place to place. Noncalcareous terrigenous clastic rocks and conglomerate are generally confined to the basal part of the member and rarely exceed a few tens of feet in thickness. Relatively pure carbonate rocks form a minor part of the thicker sections, and volcanic rocks are found within the lower member in one small part of the Humboldt Range.

The more abrupt lateral changes in the lower member occur in the northern part of the Humboldt Range, where the member was first deposited and attains its greatest thickness and yet locally is largely cut out against two prominent highs on the Koipato basement. One of these basement highs is in the northwestern part of the range and is centered around the head of Star Canyon and the upper parts of Humboldt and Imlay Canyons, and the other extends through the Arizona mine area near Unionville on the east side of the northcentral part of the range. For brevity, these features are termed, respectively, the Star-Humboldt basement high and the Arizona basement high. Their configurations, as indicated by lateral variations in the thickness of the lower member of the Prida Formation, are shown in figure 9. (See section on paleogeographic interpretation, p. 25.)

Away from these basement highs, thick sections of the lower member of the Prida crop out in two separate areas in the northern part of the range: along the east flank from Buena Vista Canyon northward, and on the west side of the range between Ryepatch and Eldorado Canyons. In both of these outcrop areas, the character of the lower member is generally alike; presumably this relatively thick lower Prida section is continuous across the range, although the lower member is concealed beneath younger Star Peak rocks at the head of Coyote and Buffalo Canyons between the StarHumboldt and Arizona basement highs.

The lower Prida sections on both sides of the range are as much as 400 feet thick and are composed of three distinot lithologic units : a basal unit of terrigenous clastic rocks, an intermediate unit of carbonate rocks, and an upper, distinctive brown-weathering calcareous sandstone and siltstone termed the brown calcareous sandstone unit. Of these, the basal clastic unit ranges in thickness from several feet to about 100 feet. Well stratified noncalcareous sandstone is prevalent in addition to poorly sorted grit and fine-grained conglomerate composed of debris from the underlying Koipato. The basal clastics are thickest and coarsest in grain size near the highs on the surface of the underlying Koipato. The coarsest clastics were observed at the base of the lower member near the mouth of the North Fork of Straight Canyon on the northwest flank of the Arizona basement high. Here, much of the basal clastic unit is a boulder conglomerate formed of flow-banded rhyolite felsite from the locally underlying Rochester Rhyolite.

The carbonate unit, above the basal clastic unit, attains a maximum thickness of about 300 feet near the east front of the range between Coyote and Bloody Canyons. It is variable in composition but consists largely of silty or sandy gray limestone irregularly interbedded with subordinate units of yellow-brown or reddish-brown calcareous siltstone and sandstone. Commonly, the limestone is crystalline and coarse grained, but some beds or,concretions of fossiliferous dense argillaceous limestone are locally included. Near the basement highs-for example, in the vicinity of Congress Canyon - the carbonate unit is thinner and somewhat intergradational with the underlying basal clastic unit. The carbonate unit here consists mainly of thick-bedded 
dolomite having sand- or even grit-sized terrigenous clastic impurities and interbeds. Fossils from this unit suggest that a disconformity exists within the unit in the vicinity of John Brown Canyon and that its upper part is progressively cut out toward the Arizona basement high.

The brown calcareous sandstone unit forms the highest part of the thickened lower member in the northern part of the range and consists of massive calcareous or dolomitic siltstone and very fine grained sandstone that weathers pale reddish brown and yellowish brown. These rocks characteristically part at a high angle to the bedding and form a distinctive brown slabby talus (fig. 5) that is conspicuous at a number of places in the northern part of the range. The brown calcareous sandstone unit is nearly 300 feet thick in Congress Canyon, where interbeds and irregular patches of gray limestone form an appreciable part of its upper half, but farther away from the Arizona basement high it is mostly about 100 feet thick. Paleontologic evidence shows that most of this thinning results from interfingering of the higher parts of the brown calcareous sandstone unit into the lower part of the middle member of the Prida Formation. (See pl. 1.)

Some of the lateral variation in lithologic characters and thickness that takes place within the three successive units that form the thick lower member in the northern part of the range as they are traced toward

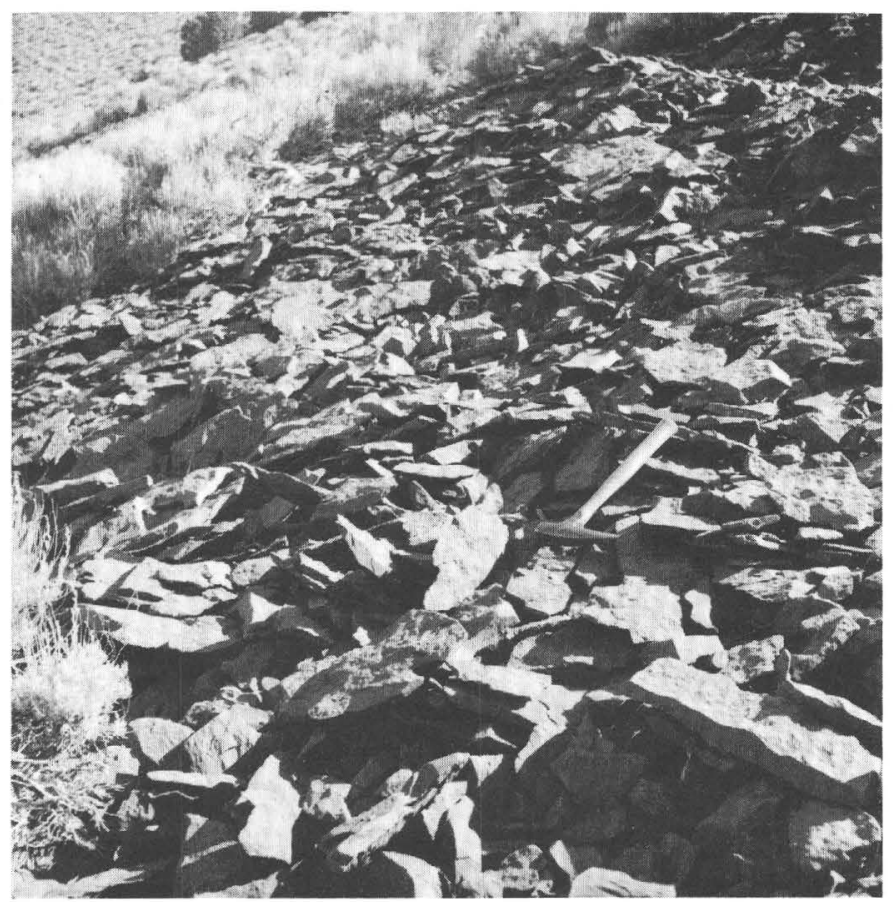

Frgure J.-Talus characteristic of the brown calcareous sandstone unit that locally forms the top of the lower member of the Prida Formation in the northern part of the Humboldt Range. East side of Congress Canyon near its mouth. the preexisting topographic highs on the Koipato surface have been described above. Near the basement highs, these units abruptly lose their individuality and at least locally are replaced by partly calcareous sandstone and conglomerate that laps up against the highs. On the east side of the range, this type of lateral change is well shown by the lower member in Star Canyon. Near the mouth of the canyon, the basal clastic unit, the carbonate unit, and the brown calcareous sandstone unit aggregate nearly 400 feet in thickness. Up the canyon, toward the Star-Humboldt basement high, they thin and in less than half a mile are replaced in the section near the Sheba and DeSoto mines by about 200 feet of sandstone and grit that includes, in the upper part, interbedded lenticular units of sandy limestone as much as several feet thick. Middle Anisian ammonites from the basal beds of the overlying middle member of the Prida here are like those that occur nearly 300 feet above the top of the lower member near the mouth of Star Canyon; hence, an appreciable amount of transgression evidently accompanies this lateral lithologic change. Still farther west, on the range crest between the heads of Star and Humboldt Canyons and on top of the StarHumboldt basement high, the entire lower member consists of only a few tens of feet of Koipato-derived clastics and brown-weathering silty dolomite. As poorly preserved fossils of probable late Anisian age occur just above in the middle member, the lower member here may be wholly younger than the thick lower Prida section on the east flank of the range.

The lateral changes within the lower member of the Prida as it is traced from its extensive exposures on the west side of the range in Panther, Echo, and Buffalo Canyons southeastward across the range crest toward the Arizona basement high are unique in that mafic volcanic rocks are included in the sections alongside the basement high. At the head of Echo Canyon, a thick lens of metavolcanic rock fragments in a dolomitic matrix occurs within impure dolomite and limestone of the carbonate unit of the lower member, and at the head of Panther Canyon a thin flow of mafic metavolcanic rock intervenes at about this same level in the section. About $11 / 2$ miles farther south along the range crest, near "Wright Peak" (VABM 8882), vesicular mafic metavolcanic rocks form the entire upper part of the lower member, supplant the brown calcareous sandstone unit, and directly underlie the middle member of the Prida. The extrusive nature of these volcanic rocks is clearly shown by the intimate mixture of brecciated amygdaloidal volcanic fragments and brown-weathering silty dolomite like that which underlies the volcanic rocks (fig. 6). At the next exposure to the east, about 1 mile distant, at Fourth of July Flat, mafic metavolcanic 


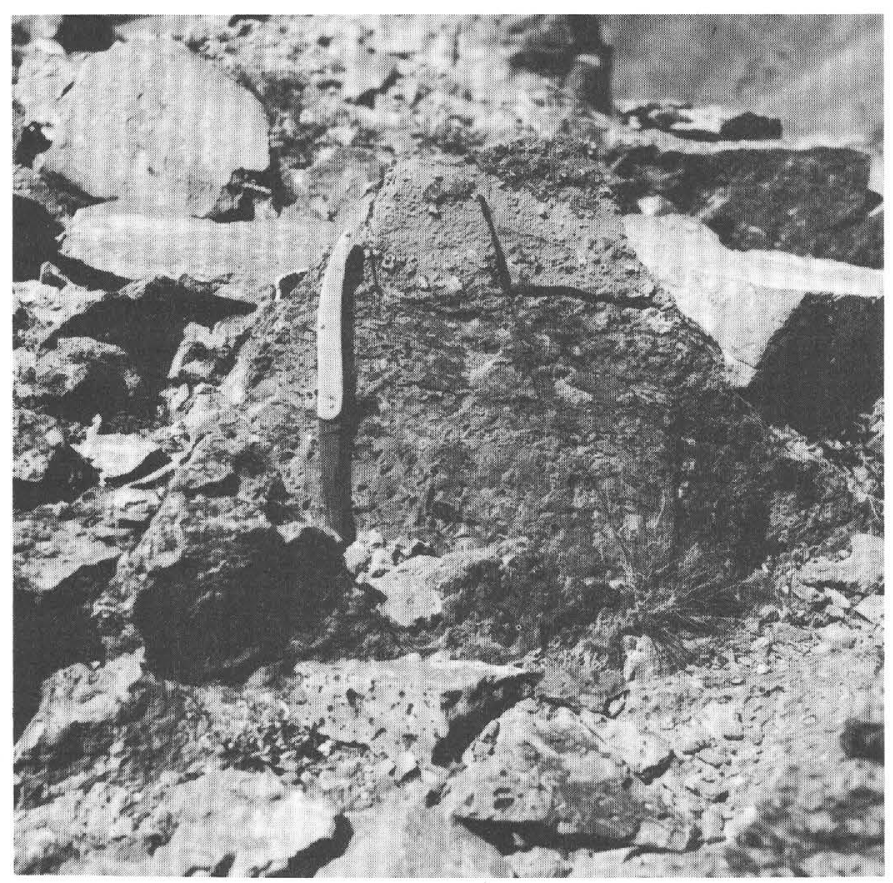

FIGURE 6.-Weathered block composed partly of vesicular and amygdaloidal mafic metavolcanic rock (lower part) and partly of impure silty dolomite (upper part). Lower member of the Prida Formation on the range crest about half a mile northwest of "Wright Peak" (VABM 8882).

rocks again form much of the lower member, but here basal clastics are absent and the volcanic unit is overlain by about 20 feet of noncalcareous grit and sandstone. The clastic unit that forms the top of the lower member can be traced eastward to the vicinity of the Arizona, Inskip, and Wheeler mines, where it becomes the basal clastic unit of a greatly thinned (total 10-30 ft) lower member consisting of basal clastic rocks overlain by impure dolomite. Thus, metavolcanic rocks in the lower member intertongue northwestward from Fourth of July Flat with a thick nonvolcanic lower member, but east of Fourth of July Flat, they abruptly lap up against the west slope of the Arizona basement high. The east slope of this basement high is marked by the rapid progressive thickening of the lower member eastward from the Arizona mine area on the spur between Jackson and Buena Vista Canyons. Both the stratigraphic relations and the paleontological evidence indicate that deposition of the lower member atop the Arizona basement high began after most or all of the thicker section of the lower member to the west, north, and northeast had already been formed.

South of Cottonwood Canyon, which limits the southward extent of the Prida outcrops in the vicinity of the Arizona group of mines, the lower part of the formation is not exposed on the east side of the range for nearly 10 miles. Unfortunately, exposures of the Prida along the west margin of the central part of the range are too deformed and altered for meaningful stratigraphic comparison. Nevertheless, the lower member of the Prida in the southern part of the range south of American Canyon is generally like that in the Arizona mine area and is probably not a temporal equivalent of the thick lower member in the more northerly parts of the range. (See pl.2.)

In the southern part of the range, the lower member is fairly uniform from place to place and comprises basal clastics overlain by silty and sandy dolomitic and calcareous rocks. The principal lateral variations are in thickness, which ranges from about 150 feet on the east side of the range to only a few feet on the west side of Black Ridge. The basal clastic unit in the vicinity of South American and Troy Canyons is generally less than 10 feet thick, but on the south side of Fisher Canyon its thickness varies within a few hundred yards along the strike from several feet to several tens of feet. These noncalcareous clastic rocks are commonly pebbly grit of poorly rounded Koipato fragments whose white and brown colors impart a characteristic mottled appearance to fresh surfaces. Subeuhedral detrital crystals of quartz and feldspar, probably derived from a part of the Koipato such as the Weaver porphyritic rhyolite, form an appreciable part of the coarse sand grains. In places, well-stratified sandstone interlenses with these poorly sorted clastics, and the thicker sections include conglomerate of rounded pebbles up to 2 inches in diameter.

Above the basal clastic unit the greater part of the lower member in the southern part of the range is slightly silty fine-grained dolomite that is medium gray on fresh surfaces, weathers a distinctive pale yellowish brown, and locally contains nodular lenses of dark chert. These rocks tend to be massive, but in places they alternate with platy-weathering gray, pinkish-gray, or yellowish-brown silty or sandy limestone and dolomitic siltstone. An unusual occurrence in the lower member in several different fault blocks north of Troy Canyon is a several-foot-thick bed of closely packed gray limestone spheres in a brown sandy dolomitic limestone matrix. These spherical bodies, $10-20 \mathrm{~mm}$ in diameter, consist of an outer rim of fine-grained crystalline calcite surrounding a coarsely crystalline sparry calcite interior. Their size, shape, and composition suggest Girvanella-like algae whose finer structure has been obliterated by recrystallization. The highest brown-weathering dolomitic rocks of the lower member between Troy and American Canyons are distinctive in that they contain seattered granules and coarse grains of light-colored siliceous Koipato fragments. Relatively coarse grained 
terrigenous detritus also appears in this part of the Prida in Fisher Canyon, where coarse-grained dolomitic sandstone locally forms the top of the lower member.

\section{MIDDLE MEMBER}

The middle member of the Prida Formation, unlike the lower member, is relatively uniform in lithologic character both vertically and laterally. It thickens progressively from a few tens of feet in the southern part of the Humboldt Range to several hundred feet in the northern part of the range as a result of the inclusion of older beds at the base of the middle member northward. The Star-Humboldt and Arizona basement highs, which so profoundly influenced the character of the lower member of the Prida in the northern part of the range, also affected deposition of the middle member. Three hundred feet or more of the middle member along the east edge of the range north of Coyote Canyon was deposited before deposition of the middle member atop these basement highs commenced.

The middle member consists of laterally discontinuous thin- and medium-bedded medium- to dark-gray limestone that rarely forms units more than a few feet thick and is interbedded with calcareous silty shale and yellowish-brown or pinkish-gray very thin bedded calcareous siltstone. Locally the limestone is highly fossiliferous and formed in large part of more or less fragmentary shells of cephalopods and, in the higher parts of the section, of the pelecypod Daonella. In weathered surface debris, limestone float predominates, but the interbedded argillaceous and silty rocks actually form more than two-thirds of the section. Although the limestone is fine grained, it is completely recrystallized; and the molluscan shell material is coarsely crystalline, even where fossil preservation is relatively good.

Five samples of black fossiliferous limestone from the middle member in the vicinity of Fossil Hill were included in the survey of carbon and oxygen isotopic composition of limestones by Keith and Weber (1964). Three of these samples had anomalously low $\mathrm{C}^{13}: \mathrm{C}^{12}$ ratios in comparison with average marine limestones; the other two samples showed the same tendency to a lesser degree. Keith and Weber suggested that the relatively low $\mathrm{C}^{13}$ content of carbonate rocks of this kind results from deposition in an environment characterized by an abundance of decaying organic matter and restricted circulation.

A conspicuous stratigraphic marker within the middle member in the southern part of the range is a unit about 10 feet thick of massive brown-weathering medium- to thick-bedded sandy limestone. This unit, which corresponds to the Gymnotoceras dunni beds of the
Gymnotoceras meeki Zone, occurs near the top of the member in the vicinity of Fossil Hill between South American and Troy Canyons, where the middle member is 150-200 feet thick, and near the middle of the thinner section of the member in Fisher Canyon. Examined microscopically, the sandy detritus can be recognized as rhyolitic debris, but partial replacement by calcite has completely obliterated the original grain boundaries, and silica has been redistributed throughout the rock in irregular patches of microcrystalline quartz which may in places replace the original carbonate.

The contact between the middle and upper members of the Prida is gradational through a few tens of feet and is marked by transition upward to darker gray regularly bedded commonly cherty carbonate rocks that generally lack argillaceous and silty interbeds. Where shearing and alteration is intense, separation of the middle and upper members is difficult; in places on the west flank of the range, no attempt was made to differentiate them on the geologic map.

UPPER MEMBER

The upper member of the Prida forms the greater part of the formation throughout the Humboldt Range. On the south wall of Fisher Canyon it is about 600 feet thick and forms about three-fourths of the entire formation. To the southwest in this same outcrop belt, both the middle and upper members thin to a combined thickness of only a few hundred feet on the west side of Black Ridge. North of Fisher Canyon the upper member increases in thickness. It is about 1,500 feet thick in Congress Canyon and may exceed 2,000 feet in thickness in the high, northern part of the range, where the upper member forms nearly half of the total preTertiary outcrop area.

This disproportionate thickness of the upper member in the northern part of the Humboldt Range significantly changes the gross character of the Prida Formation from that at its type area in the East Range, and the upper member could properly be recognized as a separate formation. This is not done, however, because the lithologic distinction between the upper and middle members is commonly obscured by secondary deformation and recrystallization, and these two units are not easily differentiated in some parts of the range.

The characteristic rocks of the upper member are thin- and medium-parted, conspicuously laminated medium- to dark-gray limestone and dolomite with lenticular stringers and thin beds of dark chert (fig. 8B) Repetitious thin- to medium-parting units with somewhat undulating surfaces give most exposures a regularly stratified appearance (fig. 7). Interstratified with 


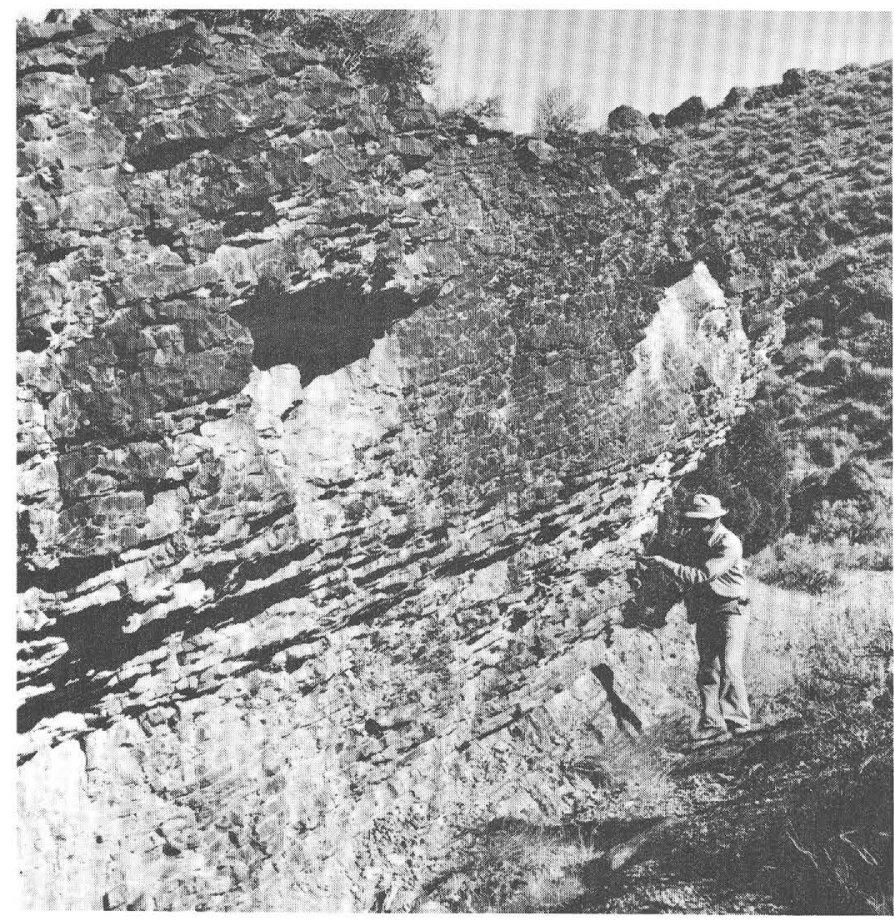

FIGURE 7.-Outcrop of dark laminated dolomite showing the thin to medium-thick, somewhat undulating parting characteristic of much of the upper member of the Prida Formation. Near east front of the range north of American Canyon.

these rocks are thick and very thick beds of massive medium- and coarse-grained organic-detrital carbonate rock that form units up to a few tens of feet thick and become increasingly abundant towards the top of the member. These massive carbonate rocks are essentially like those of the overlying Natchez Pass Formation, which is distinguished from the upper member by the absence of cherty laminated carbonate rocks.

The lamination of the regularly bedded cherty carbonate rocks results from the alternation of finely crystalline layers with very finely crystalline more carbonaceous layers. Though entirely fine grained, these rocks are wholly recrystallized. Detrital silt grains of quartz, chert, and feldspar are ubiquitous in amounts up to several percent, and wispy stringers and thin beds of yellowish brown silty carbonate rock are common in places, particularly in the southern part of the range. The distribution of calcareous and dolomitic facies in these rocks lacks any apparent regularity, and much of the dolomitization is evidently secondary, perhaps of hydrothermal origin. Scattered fine-grained dolomite euhedra indicate partial dolomitization in places, but the rocks that are entirely dolomitic have a granoblastic texture.

Chert stringers and layers constitute at least several percent of the section, and in the northern part of the range thin-bedded dark chert locally forms continuous units as much as a few tens of feet thick within the upper member. Though megascopically the boundaries between the chert bodies and the enclosing carbonate rocks are sharp, as viewed in thin section they are irregular and ragged, and both euhedra of dolomite and patches of carbonate are included within the chert. The chert is composed of microcrystalline quartz and evidently represents reconstituted layers of original silceous organic-detrital material in some places and the replacement of original calcareous detritus in other places. Some thin chert beds in the section in Congress Canyon contain abundant outlines of sponge spicules and radiolaria, but this is unusual; similar chert beds more commonly have only a faint internal lamination with sporadic clear round spots that may have been radiolaria. Dolomite euhedra in these layers clearly replace the chert: they tend to cluster along crosscutting veinlets, and they transect the original outlines of radiolaria. In other places, particularly in the relatively thin section of the upper member in the southern part of the range, ghosts of originally calcareous pellets and shell fragments are preserved in patches and stringers of microcrystalline quartz that represent selective replacement of local concentrations of relatively coarsegrained calcareous detritus within the fine-grained laminated rocks. Some of these chert bodies accurately retain the original depositional form of these organic detrital accumulations, and the lamination of the enclosing carbonate rock is bent around them. Others were evidently infolded into the underlying carbonate layers as load casts and then truncated before burial and silicification.

Deposits of sedimentary breccia formed of somewhat rounded fragments of featureless carbonate rocks up to at least several inches in greatest dimension in a coarse clastic carbonate matrix (fig. 8A) are a significant, though infrequent, occurrence in the upper member of the Prida. These occur as discontinuous thick units and are interpreted as submarine slide deposits. Locally their emplacement contorted and broke the underlying laminated carbonate rocks, as is shown in the specimen illustrated (fig. $8 C$ ). This specimen is from beneath the slide breccia exposed at the summit of Fossil Hill. Both the laminated carbonate and the thin chert interbeds were broken into angular fragments, implying considerable penecontemporaneous induration of these sediments. Some other isolated occurrences of contorted bedding in the upper Prida are probably also the result of submarine sliding and slumping, but in the northern part of the range these are difficult to distinguish from the effects of the more general tectonic deformation. 
Discontinuous units of altered volcanic rocks form a minor part of the upper member in the northern part of the range. Some of these rocks are obviously extrusive, whereas others probably represent feeder dikes. Near Star Peak, amygdaloidal flow rocks and volcanic breccia locally form the highest part of the upper member and directly underlie the Natchez Pass Formation. Similar mafic metavolcanic rocks appear at places on the west flank of the range from Echo Canyon northward at about the same stratigraphic level high in the upper member of the Prida Formation. The thickest and most extensive of these volcanic units is exposed intermittently for about 2 miles between Humboldt and Prince Royal Canyons in an eastward-plunging overturned syncline beneath the Humbolt City thrust. On the north wall of Humboldt Canyon this unit exceeds 200 feet in thickness and locally includes pillowlike structures up to several feet in size embedded in a limy tuffaceous matrix that ecntains poorly preserved marine fossils. The mafic igneous rocks that forms a large outcrop on the range crest about 2 miles north of Star Peak is evidently an altered diabase now composed largely of plagioclase and chlorite. Its contact cuts across the bedding of the Prida at a low angle, and it is considered to be a dike related to the extrusive rocks in the Prida or in higher parts of the Star Peak Group.

\section{FOSSILS AND AGE}

The age of the Prida Formation in the Humboldt Range is well established by ammonite and halobiid pelecypod faunas. (See fig. 3.) Locally, in the northern part of the range where its thickness and time span are greatest, the Prida ranges from late Early Triassic to early Late Triassic in age; farther south, where its deposition began later and where its upper part is supplanted by massive carbonate rocks of the Natchez Pass Formation, the Prida is wholly of Middle Triassic age.

In the lower member of the Prida Formation along the northeast flank of the range between $\mathrm{J}_{\text {ohn }}$ Brown and Santa Clara Canyons, where this member is thickest, most calcareous, and not too badly sheared and recrystallized, at least two distinct successive ammonite faunas occur. The older of these is termed the $S u b$ cotumbites fauna, and the younger fauna is that of the Neopopanoceras haugi Zone. The composition and stratigraphic occurrence of these faunas, as well as those from the overlying lower parts of the middle member, are shown in table 1 and on plate 1.

The older fauna from the lower member is best represented by collections made from limestone concretions that occur at a consistent stratigraphic level about 50 feet above the basal clastics at USGS Mesozoic locality M2360 and along strike for several hundred feet between
Coyote and Bloody Canyons. The presence of Subcolumbites and species of Prohungarites place this fauna near the top of the Lower Triassic and relatively high in the Spathian Stage, the youngest of the four Lower Triassic stages recently introduced by Tozer (1965b, 1967). Among float collection made nearby from USGS Mesozoic locality M1688, the Prohungarites referred to in table 1 as $P$. n. sp. " $\mathrm{B}$ " is probably from a stratigraphic level only slightly above that of locality M2360. It is like the species of Prohungarites characteristic of the "Prohungarites beds" at Hammond Creek, Bear Lake Valley, southeastern Idaho (Bernard Kummel, written commun., 1965), the fauna of which has been listed by Kummel (1954, p. 187). The Subcolumbites beds of northwestern Nevada and the Prohungarites beds of southeastern Idaho are therefore regarded as approximate temporal equivalents by Silberling and Tozer (1968).

Of significance for reconstructing the depositional history of the lower Mesozoic rocks of northwestern Nevada is the fact that ammonite species such as Prohungarites sp. "B", Zenoites? sp. "A", and Subcolumbites sp. "A", which occur in the oldest parts of the Prida Formation, also occur a few tens of feet above the base of the Tobin Formation at USGS Mesozoic locality M2565 near the south end of the Tobin Range. Hence, locally, as in the northern Humboldt Range, the Prida Formation at the base of the "Winnemucea sequence" of lower Mesozoic strata includes beds as old as the Tobin Formation at the base of the "Augusta sequence," contrary to the view previously held by Silberling and Roberts (1962, p. 37). Another fauna from about the same stratigraphic position in the Tobin Formation of the Tobin Range, but from a locality about 2 miles farther south, is currently being described by Prof. Bernard Kummel. Though this fauna lacks Prohungarites and contains a different species of Subcotumbites, it is otherwise generally similar in composition and is probably not much different in age.

The Neopopanoceras haugi fauna, represented especially by "Hungarites" yatesi and distinctive species of paranannitids, has been found in the lower member of the Prida Formation at several places along the northeast flank of the Humboldt Range from Bloody Canyon south to the south side of Coyote Canyon. It occupies a consistent stratigraphic level within a few tens of feet below the brown calcareous sandstone unit that forms the highest part of the lower member in this part of the range. Hence, although it has not been found directly above the Subcolumbites fauna, its position in the section between Coyote and Bloody Canyons, where the carbonate unit of the lower member is thickest, is about 


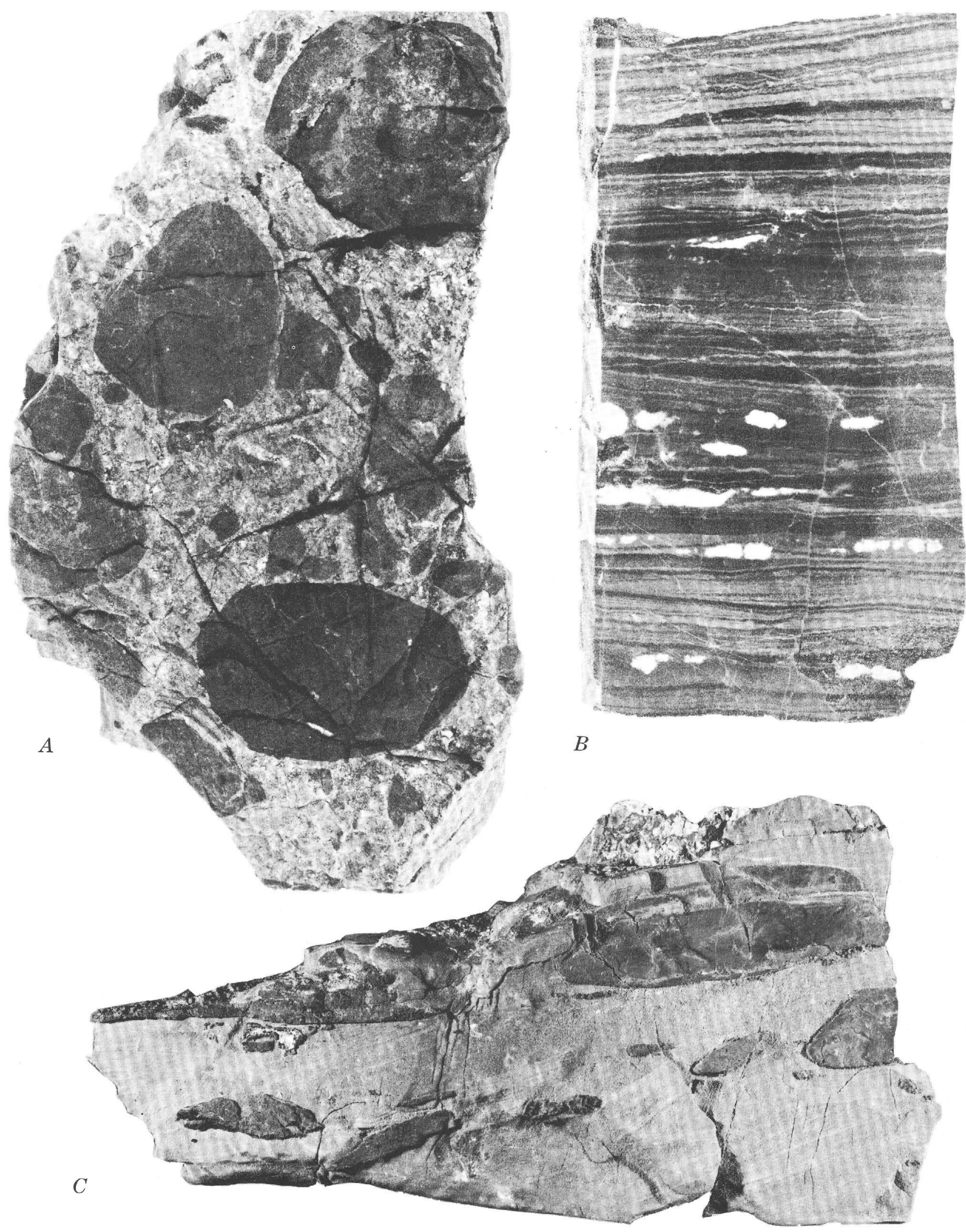


TABLE 1.-Composition and biostratigraphic assignment of the ammonite faunas from the lower part of the Prida Formation in the northeastern part of the Humboldt Range

[Location of USGS Mesozoic localities shown on pl. 1. X, occurrence or species'?, uncertain occurrence]

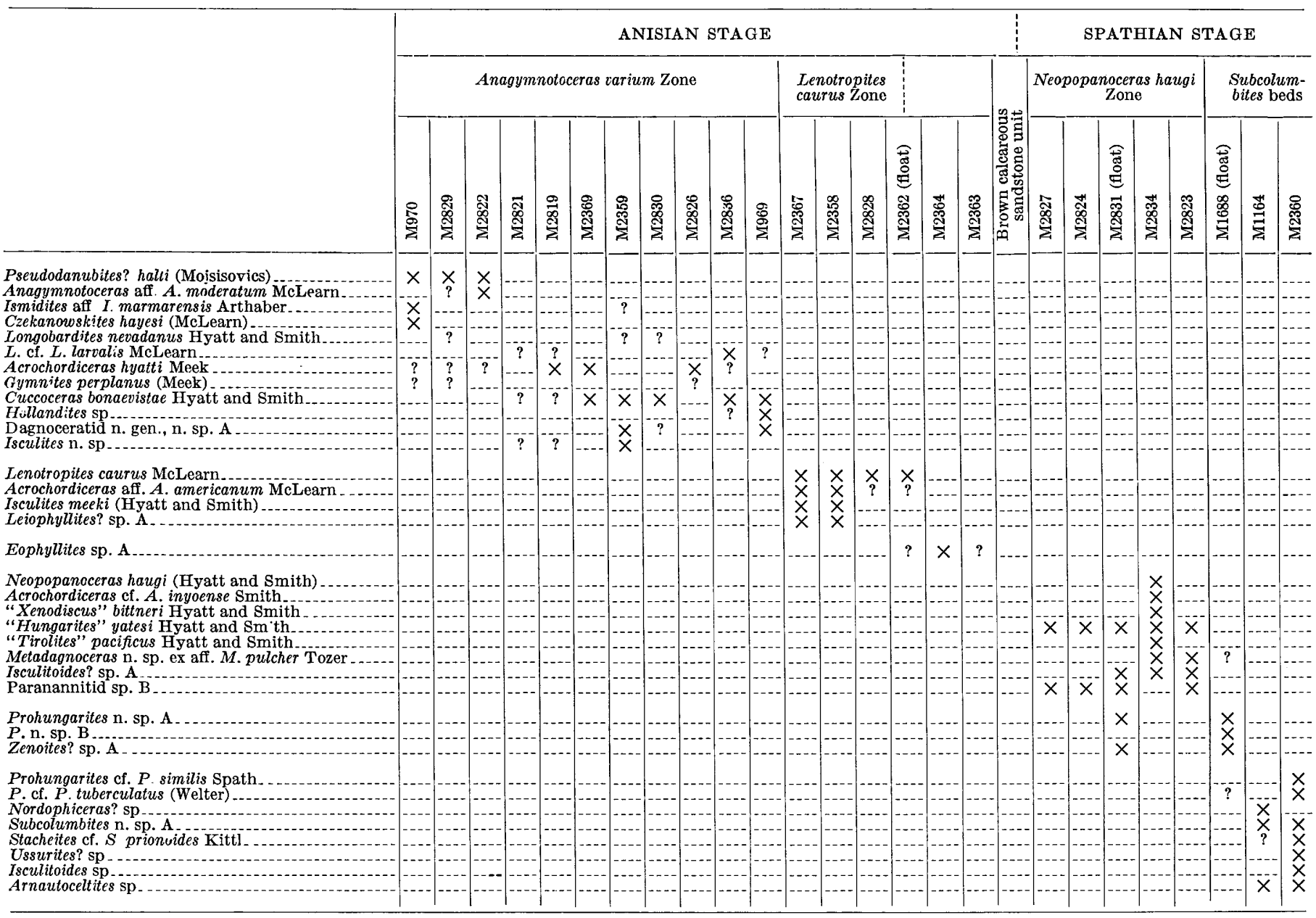

200 feet higher than that of the Subcolumbites beds such as those at locality $\mathbf{M} 2360$.

South of Coyote Canyon, where the carbonate unit is much thinner, the relative superposition of the $\mathrm{NeO}$ popanoceras haugi and Subcolumbites faunas is obscure. In John Brown Canyon the stratigraphic position

Figure 8.-Carbonate rocks from the upper member of the Prida Formation on Fossil Hill, in the southeastern part of the range. All figures natural size. $A$, Dolomite sedimentary breccia from thick discontinuous unit interpreted as a submarine slide deposit within the laminated thin-bedded limestone and dolomite of the upper member. $B$, Laminated dolomitic limestone like that which forms most of the upper member. Sawn slab photographed in liquid to heighten contrast between laminae. White patches are void fillings of sparry calcite and quartz. Stratigraphic orientation of hand specimen uncertain. $C$, Weathered surface of brecciated and recemented very thinly interbedded laminated dolomite (light colored) and chert (dark colored). Disruption of bedding attributed to emplacement of carbonate slide deposit that directly overlies these rocks in the section. of the $N$. haugi Zone, which can be recognized as far southwest as USGS Mesozoic locality M2823 near the mouth of this canyon, is apparently occupied instead by Subcolumbites beds, as at USGS Mesozoic locality M1164. To explain this, a disconformity within the carbonate unit here is postulated on plate 1 . In support of this interpretation, the beds that would be separated by this disconformity are quite different in composition; the carbonate unit at locality M1164 is composed of coarse-grained organic-detrital sandy limestone, whereas the Neopopanoceras haugi Zone a short distance farther northeast consists of well-bedded dense argillaceous gray limestone. Moreover, locality M1164 is near the depositional margin of these rocks of the lower member where they lap up against the Arizona basement high, and gaps in the section might be expected here.

Heretofore, the only known occurrence of the $\mathrm{NeO}$ popanoceras haugi fauna was in the Inyo Mountains of southeastern California, where it is not in close strat- 
igraphic succession with other faunas. In the absence of an adequate means of dating this unique assemblage, its age has been customarily regarded as earliest Middle Triassic (Smith, 1914, p. 5-6; Spath, 1934, p. 35; Arkell and others, 1957, p. L124). Collections from the $N$. haugi Zone at USGS Mesozoic locality M2834 near the edge of the Humboldt Range just south of Coyote Canyon include most, and perhaps all, of the ammonites originally ascribed to it in the Inyo Mountains by Smith (1914) plus a few additional kinds. (See table 1.) Compared with the faunal succession found elsewhere in North America, the relative position of this fauna in the Humboldt Range with respect to the lower Anisian "Longobardites" caurus Zone indicates that the $N$. haugi Zone is approximately equivalent to the uppermost Lower Triassic Kyserlingites subrobustus Zone of arctic regions (Silberling and Tozer, 1968). A further reason for considering the $N$. haugi Zone as highest Lower, rather than lowest Middle Triassic is the recent discovery of poorly preserved ammonites probably belonging to the uppermost Lower Triassic genus Keyserlingites several tens of feet stratigraphically above the $N$. haugi beds in the Inyo Mountains. "Keyserlingites? sp. indet." is, in fact, listed by Smith $(1914$, p. 6) from the $N$. haugi Zone of the Inyo Mountains, but this identification cannot be confirmed.

The middle member of the Prida Formation in the Humboldt Range includes perhaps the most complete succession of Anisian ammonite faunas known anywhere in the world. These faunas have been partly described by Gabb (1864), Meek (1877), and Hyatt and Smith (1905), and they formed the basis for Smith's monographic treatment of the Middle Triassic marine invertebrate faunas of North America (Smith, 1914). These previous authors, however, gave little or no attention to the stratigraphic distribution of these faunas. The research described here and in another paper being prepared by Silberling demonstrates the existence of as many as 15 distinct, stratigraphically successive, Anisian ammonite faunas in the middle member of the Humboldt Range. In terms of biostratigraphic units that are more or less coordinate in rank with those recognized elsewhere in the Triassic of North America, the beds characterized by these faunas are grouped into five successive ammonite zones.

Lower and middle Anisian faunas are represented only in the northern parts of the range, where the middle member is thickest and has its greatest age span. Unfortunately, the preservation of fossils here is for the most part poor. Owing to the generally transgressive nature of the Prida southward in the range, none of the middle member is as old as early or middle Anisian in the southern parts parts of the range. Upper Anisian ammonite faunas occur in the middle member throughout the range, but they are best developed in the southeast part of the range at localities such as the classic collecting site at Fossil Hill.

The Anisian faunas of the Humboldt Range are dominated by cephalopods and by planktonic or probable pseudoplanktonic pelecypods; Posidonia-like forms and "Sphaera" whitneyi Meek are prevalent in the middle Anisian whereas species of Daonella and "Rhynchopterus" obesus Gabb are well represented in the upper Anisian. With few exceptions, brachiopods and gastropods are scarce, and other kinds of larger marine invertebrate fossils are unkown.

Where the lower and middle members of the Prida are thickest, in the northeastern part of the range, fossils have been found at several places in the basal beds of the middle member just above the brown calcareous sandstone unit that forms the top of the lower member. In the vicinity of Star Canyon, as at USGS Mesozoic locality M2364, an abundance of the ammonite Eophyllites sp. "A" and the brachiopod Spirigera cf. S. stoliczkai Bittner locally characterizes the lowermost few tens of feet of the middle member. No refined age significance can be attributed to these fossils, however, and the ammonites found at other localities from the same stratigraphic level, though exhibiting appreciable variety, are wholly indeterminate.

In the same general area-for example, at USGS Mesozoic localities M2358 and M2828-a discrete ammonite fauna characterized by Isculites meeki (Hyatt and Smith) and Lenotropites caurus (McLearn) occurs 100-150 feet above the base of the middle member. The presence of the latter species and of associated specimens of Acrochordiceras, which are closer to A. americanum McLearn than to any other described species, indicates that this part of the section is in the L. caurus Zone, which is typical of northeastern British Columbia and is the oldest zone recognized in the Anisian of North America (Silberling and Tozer, 1968; Tozer, 1967).

The next higher ammonite zone, to which the Canadian name Anagymnotoceras varium Zone (Silberling and Tozer, 1968) is applicable, is as much as 150 feet thick; it is distinguished by the best developed and most widely distributed ammonite fauna found in the Prida Formation in the northern part of the Humboldt Range. In those places where the Prida laps onto topographic highs on the preexisting Koipato surface, the $A$. varium. Zone may occur immediately above whatever rocks locally constitute the lower member. Away from such basement highs, as along the east front of the range north of Coyote Canyon, the lowest fossils of the $A$. varium Zone are found up to 300 feet above the base of the middle member and are 100-125 feet above the fossiliferous beds of the L. caume Zone. 
In addition to the occurrences of $A$. varium Zone fossils shown on plate 1, other significant localities at which cephalopods of this zone occur are USGS Mesozoic localities M533, M969, M1180, M1181, and M1875 on the east side of the range north of Unionville.

Some ammonite species characteristic of the $A$. varinm Zone in the Humboldt Range (table 1), such as Acrochordiceras hyatti Meek (not Smith and other authors) and perhaps Gymnites perplanus Meek, range through the zone; others are more stratigraphically restricted 'within the zone. Cuccoceras bonaevistae. Hyatt and Smith, Longobardites cf. L. larvalis McLearn, and Isculites $\mathrm{n}$. sp. are evidently confined to the lower part of the zone, whereas Pseudodanubites? halli (Mojsisovics), Longobardites nevadanus Hyatt and Smith, and Czekanowskites hayesi (McLearn) have been found in its higher parts only.

The Anagymnotoceras varium Zone is assigned to the middle Anisian as recognized in North America by Silberling and Tozer (1968). It is regarded as older than the middle Anisian Balatonites shoshonensis Zone, the other North American ammonite zone assigned by Silberling and Tozer to the middle Anisian, but the two zones have not been found in stratigraphic sequence. Up to the present time the $B$. shoshonensis Zone has been found only in the Favret Formation, which crops out in the Augusta Mountains and adjacent parts of northwestern Nevada southeast of the Humboldt Range. Some genera such as Acrochordiceras and Longobardites occur in both zones but are represented in the $B$. shoshonensis Zone by species that appear to be more advanced morphologically than those in the $A$. varium Zone, and some genera such as Proarcestes and Ptychites, that range up into younger strata are found in the B. shoshonensis Zone but not in the $A$. varium Zone. The 150 feet or so of the unfossiliferous beds that separate the $A$. varium Zone from the upper Anisian Gymnotoceras rotelliformis Zone in the northern Humboldt Range leave ample room in the section for middle Anisian strata correlative with the $B$. shoshonensis Zone.

Upper Anisian ammonite and Daonella faunas are widely distributed in the uppermost 100 feet of the middle member of the Prida Formation in the Humboldt Range, although nowhere are they as completely developed and as well preserved as in the vicinity of Fossil Hill between Troy and South American Canyons. The upper Anisian section here is the type locality for the Gymnotoceras rotelliformis, Gymnotoceras meeki, and Gymnotoceras occidentalis Zones of Silberling and Tozer (1968), which heretofore have been lumped informally into an all-inclusive "Gymnotoceras zone" (Silberling, 1962, p. 153). These faunas were monographed by Smith (1914), who treated them as a single, stratigraphically equivalent assemblage. The preliminary revision of their taxonomy and stratigraphic distribution by Silberling (1962) now requires some modifications, the most important of which are (1) the recognition of Gymnotoceras rotelliformis as a distinct species occurring below, but intergrading with, G. blakei; (2) the inversion of the Paraceratites clarke $i$ and $P$. vogdesi beds and the recognition of a still older level, the P. burckhardti beds; (3) the combination of Gymnotoceras washburnei and $G$. occidentalis, as first revised, under $G$. occidentalis; and (4) the transfer of "Anolcites" furlongi and "A." gabbi to the genus Nevadites.

Incorporating these changes, the sequence of upper Anisian faunal units recognized in the Fossil Hill area, listed from youngest to oldest, and their grouping into zones, is as follows:

\section{Gymnotoceras occidentalis Zone \\ Nevadites gabbi beds \\ Nevadites furlongi beds \\ Nevadites humboldtensis beds \\ Nevadites hyatti beds \\ Gymnotoceras meeki Zone \\ Gymnotoceras dunni beds \\ Gymnotoceras meeki beds \\ Gymnotoceras (Frechites) nevadanus beds \\ Gymnotoceras rotelliformis Zone \\ Gymnotoceras blakei beds \\ Paraceratites cricki beds \\ Paraceratites vogdesi beds \\ Paraceratites clarkei beds \\ Paraceratites burckhardti beds}

Some faunal resemblance exists between the $G$. rotelliformis and $G$. meeki Zones and the typical upper Anisian of Alpine Europe. The $G$. occidentalis Zone, however, is regarded as upper Anisian rather than lower Ladinian because the typically Ladinian ammonite genus Protrachyceras makes its first appearance in the next higher, Protrachyceras subasperum Zone in the lowest beds of the upper member of the Prida.

Although larger marine invertebrate fossils other than cephalopods and a few kinds of pelecypods are either scarce or absent in the middle member of the Prida, some other kinds of fossils do occur. Skeletal remains of ichthyosaurian reptiles are fairly common, particularly in the beds containing the greatest concentration of ammonite shells. The specimens of ichthyosaurs, including one nearly complete skeleton, described by Merriam (1908), are from the upper Anisian in the vicinity of Fossil Hill. Fish teeth and spines, presumably from localities in the middle member, have been 
described respectively by Wemple (1906) and Davidson (1919). Mosher and Clark (1965) reported that conodonts are abundant in the Gymnotoceras rotelliformis, meeki, and occidentalis Zones in the vicinity of Fossil Hill and that the same assemblage of species, which is like that known from the Anisian of Europe, apparently ranges through all three zones.

The top of the $G$. occidentalis Zone roughly coincides with the lithic transition between the middle and upper members of the Prida Formation throughout the Humboldt Range. In the vicinity of Fossil Hill and at a few other places, as in the Arizona mine area, the lowermost few tens of feet of the upper member are characterized by primitive species of Protrachyceras such as $P$. subasperum, and by Daonella aff. $D$. taramellii. These beds are termed the Protrachyceras subasperum Zone and are regarded as earliest Ladinian in age (Silberling and Tozer, 1968).

Except for the P. subasperum Zone at its base, the upper member of the Prida is poorly fossiliferous; throughout most of the member the only fossils found are scattered specimens of trachyceratid ammonites that are mostly flattened, silicified, and generally indeterminate. In the higher parts of the upper member, however, pelecypods closely similar to, or identical with, Daonella lommeli Wissman, an index fossil of the Alpine upper Ladinian (uppermost Middle Triassic), have been found at several places. In Fisher Canyon (USGS Mesozoic loc. M3095) in the southern part of the range, these pelecypods and an additional undescribed species of Daonella occur about 50 feet below the top of the Prida. In Congress Canyon (USGS Mesozoic loc. M907), D. cf. $D$. lommeli was found with a few poorly preserved ammonites of the long-ranging genera Protrachyceras?, Proarcestes, and Hungarites about 600 feet below the top of the upper member at about the level where thick interbeds of massive carbonate rocks become conspicuous within the Prida section. And at the northeastern tip of the range, west of Nevada State Highway 50 (USGS Mesozoic loc. M1689), Daonella cf. D. lommeli again occurs in the upper member of the Prida within a few tens of feet below the base of the overlying Natchez Pass Formation. Although this species may have an appreciable stratigraphic range, this variation in the amount of Prida section above its occurrence in different places (pl. 2) is great enough to indicate that the upper limit of the Prida is somewhat younger in the north-central part of the Humboldt Range than it is in the southern and the northeastern extremities of the range.

The youngest fossils in the upper member of the Prida are poorly preserved ammonites from impure limestone beds associated with thin units of mafic volcanic rock high in the section in the northwestern part of the Humboldt Range. The best of these faunas was found about half a mile north of the Standard mine (USGS Mesozoic loc. M1186) and includes Sageceras and Proarcestes along with trachyceratid and clionitid ammonites. Unfortunately, the trachyceratids cannot be positively identified, but their advanced sculpture strongly suggests assignment to Trachyceras s.s., which is indicative of an early Karnian age. An age at least this young is substantiated by their association with clionitids; a still younger age is unlikely because the genus Sageceras is not known above the lower Karnian.

\section{NATCHEZ PASS FORMATION}

The upper part of the Star Peak Group in the Humboldt Range is the Natchez Pass Formation named from exposures at Natchez Pass in the East Range. Massive carbonate rocks characterize the Natchez Pass Formation, but subordinate units of mafic volcanic rocks, terrigenous clastic rocks, and impure limestones permit its subdivision into local members and map units. The lower age limit of the Natchez Pass varies from late Ladinian in the southern part of the Humboldt Range to early Karnian in the northwestern part of the range; the upper age limit is poorly controlled but is probably late Karnian throughout the range. (See fig. 3.)

Exposures of the Natchez Pass are widely scattered in the Humboldt Range, and only those at the south end and at the northeastern tip of the range preserve a complete section of the formation. In the southern part of the range the Natchez Pass swings across Black Ridge in a broad outcrop band that forms the south flank and summit of Buffalo Mountain, and scattered outcrops then continue northward along the southeast front of the range to Indian Creek Canyon north of Fitting. To the north, on the west side of the range a nearly complete section of the Natchez Pass forms a belt paralleling the range front from Panther Canyon north to the Standard mine area, where the Natchez Pass forms the upper plate of the Standard thrust. Structurally below the Standard thrust, the upper part of the Natchez Pass then forms the sole of the Humboldt City thrust and continues northward in a narrow continuous band beneath the Grass Valley Formation along the western foothills of the range to a point north of Humboldt Canyon. In the high, northern part of the Humboldt Range incomplete sections of the Natchez Pass form the imposing limestone cliffs at the head of Congress Canyon, the crest of the range in the vicinity of Star Peak, and the summit of the 9,275-foot peak (Santa Clara Peak) about $2 \frac{1}{2}$ miles north of Star Peak. And finally, the Natchez Pass underlies most of the Mill City hills, the line of the hills projecting northeastward from the north end of the Humboldt Range. (See fig. 1.) 
In most of the Humboldt Range, the Natchez Pass Formation is divided into two readily distinguished informal members. The lower member consists of cliffforming massive carbonate rocks that in the southern part of the range interfinger with mafic volcanic rocks. An abrupt change to nonresistant impure limestone marks the base of the upper member, the higher parts of which are again composed of massive pure carbonate rocks like those of the lower member. The slope-forming impure limestone in the lower part of the upper member in the northern part of the main range includes subordinate amounts of both volcanic and terrigenous clastic rocks not represented in the equivalent part of the section farther south. Otherwise, this distinctive unit is very much the same in both parts of the range. These members are not recognized in the structurally contorted, but probably complete, section in the Mill City hills, though a thick unit of terrigenous clastic rocks, not represented elsewhere in the range, divides the recrystallized carbonate rocks of the Natchez Pass Formation here into two parts of about equal thickness.

The relative proportion of limestone and dolomite is variable among the carbonate rocks of the Natchez Pass Formation. In general the sections in the southeast and northeast extremities of the range are more dolomitic than those in the northern part of the main range, but nowhere does dolomite predominate over limestone through appreciable thicknesses of section. In its present form, much of the dolomite in these rocks is evidently a secondary replacement of limestone and commonly occurs as coarsely crystalline masses in areas of shearing or fracturing. However, some finely and medium-crystalline gray massive carbonate beds are also partly or wholly dolomitic and may have been primarily enriched in magnesium.

The total thickness of the Natchez Pass Formation in the southern part of the Humboldt Range is about 2,500 feet, the lower 1,500 feet of which represents the massive carbonate rocks and included volcanic rocks of the lower member (pl. 2). To the north, the lower member progressively thins to only several hundred feet by regressive interfingering with the underlying Prida Formation, and, assuming an approximately constant thickness for the upper member, the total thickness of the Natchez Pass in the northwestern and high, northern parts of the range may be only about half that 20 miles or so farther south. From the high, northern part of the range northeastward to the Mill City hills, the formation thickens again at the expense of the underlying Prida Formation to about 2,000 feet. This estimated thickness, however, is only a rough approximation because of the deformation of the largely overturned section here.
Wherever exposed, the contact between the massive carbonate rocks that form the highest part of the Natchez Pass and the metapelitic rocks of the overlying Grass Valley Formation is abrupt; the two rock types are not interlayered, and the transition between them takes place within a few feet. In most places the sharpness of the contact between these two rock units with different styles of deformation has been heightened by local shearing.

\section{LITHOLOGIC DESCRIPTION}

As the lithologic units that make up the Natchez Pass Formation are not the same throughout the Humboldt Range owing to lateral variations, the formation is best described as a whole in each of its principal outcrop areas rather than in terms of its various lithologic subdivisions.

In the southern part of the range, the Natchez Pass is readily divided into two members: a lower member of massive carbonate rocks that complexly intertongue with mafic volcanic rocks and locally include very subordinate amounts of terrigenous detritus, and an upper member that is wholly calcareous. The southwesternmost exposures of the lower member on the west side of Black Ridge overlooking Packard Flat are predominantly volcanic flows and breccia in several units of varying thickness interspersed with limestone units. The aggregate thickness is about 1,500 feet. Eastward across Black Ridge, massive carbonate rocks form an increasingly large part of the section, and from Cow Canyon northward along the southeastern margin of the range, they form nearly all of the member, which gradually thins to about 1,000 feet north of American Canyon. From Cow Canyon northward, volcanic rocks are restricted to the highest part of the lower member and form a laterally persistent unit several tens of feet to a few hundred feet thick separating the thick section of massive carbonates below from the impure limestone of the basal part of the upper member above.

The carbonate rocks of the lower member, where not mixed with volcanic rocks are a monotonous succession of medium-gray, thick and very thick bedded limestone and dolomite, all of which is recrystallized, somewhat broken, and pervasively veined with calcite. Massive dolomite beds are generally subordinate except near the base of the section in the vicinity of American Canyon, where they are a major constituent. Some sugary masses of light-colored crystalline dolomite crosscut bedding and evidently follow zones of fracturing. Secondary recrystallization has largely obliterated the original texture of these rocks, but enough shelly and echinodermal debris are commonly discernible to suggest that it formed an organic-detrital framework which may have been originally filled with sparry calcite matrix. Both shell fragments and matrix are now medium to 
coarsely crystalline. Large isolated fragments of recrystallized Thecosmilia-like phaceloid corals were noted in several places between Fisher and Cow Canyons, and poorly preserved silicified molluscan and brachiopod shells are not uncommon.

In the fault blocks of the Natchez Pass north of American Canyon, a bed several feet thick of wellrounded chert granules and pebbles occurs within the massive limestone and dolomite of the lower member about 400 feet above its base and forms a useful local stratigraphic marker. This bed is crudely stratified owing to wisplike variations in the packing density of the chert clasts; these clasts may be tightly packed with siliceous cement or sporadically scattered in coarsegrained organic-detrital limestone.

Another siliceous detrital unit is associated, oddly enough, with the mainly volcanic section of the lower member in the vicinity of South Relief Canyon. This unit, which is about 20 feet thick and can be traced laterally for about 1 mile in the upper part of the member, resembles in the field some of the dark sheared volcanic tuffs at other levels in the section. In thin section, however, it is seen to be composed largely of quartzose silt to which the dark color is imparted by interstitial material that may be tuffaceous in origin.

The mafic volcanic rocks in the lower member of the Natchez Pass Formation in the southern part of the range are a heterogeneous assemblage of dense or amygdaloidal nonporphyritic massive flows, breccias, and tuffs, in part intimately mixed with impure organicdetrital limestone. The flow rocks and breceia clasts are mainly yellowish brown or greenish gray and are completely altered. The plagioclase laths of the groundmass are either albitic or ghosted by calcite and sericitic material and are mixed intergranularly with chlorite, calcite, epidote-group minerals, ferric oxides, and much fine-grained "dust." No original mafic minerals are preserved in the several specimens examined petrographically. Amygdules, where present, commonly show a regular zoning. An outer rim of scattered opaque grains is bordered interiorly by microcrystalline quartz or chlorite which, in turn, borders a central filling of coarse calcite or quartz crystals. A primary volcanic origin for at least some of the breccias associated with the flow rocks is shown in thin section by devitrified, but clearly defined, glassy rims on the breccia clasts.

Stratigraphic unity is provided the laterally variable and somewhat heterogeneous lower member of the Natchez Pass by the overlying upper member, which is wholly calcareous and is constant in lithologic character throughout the southern part of the range. The lower part of the upper member is yellowish-brown and gray mostly thin- and medium-bedded limestone that forms smooth, evenly stratified brown slopes; it contrasts sharply with the upper part of the member, which is cliff-forming thick to very thick bedded massive gray limestone resembling that of the lower member. Each of these parts of the upper member is about 500 feet thick, and though the upward change from one to the other is completely gradational, they can be mapped separately. The well-bedded brown-weathering impure limestone in the lower part of the upper member differs markedly in texture from the medium or coarsely crystalline organic-detrital massive carbonate rocks that form the bulk of the Natchez Pass in most places. This impure limestone consists of partly broken pelecypod, brachiopod, and gastropod shells that have been replaced by medium-grained mosaics of calcite and are sparsely to tightly packed in a very finely crystalline calcite groundmass which could be either an original calcilutite or a micrite whose recrystallization was perhaps arrested at a very fine grain size by clay-size terrigenous impurities. The more coarsely crystalline components of the limestone, such as the molluscan and brachiopod shells and the fillings of shell interiors and fractures, commonly have a conspicuous yellowish-orange limonitic stain that contrasts strongly with the olive gray or medium gray of the matrix. The nature and amount of noncarbonate impurity in these rocks are shown by chemical analyses of two characteristic samples-one from Cow Canyon and another from American Canyon. Their $\mathrm{Al}_{2} \mathrm{O}_{3}$ content of about 1.5 percent provides an index of the amount of clay; $\mathrm{Fe}_{2} \mathrm{O}_{3}$ values are near 0.7 percent. $\mathrm{SiO}_{2}$ amounts to about 6 percent, part of which may represent quartz silt, although secondary microcrystalline quartz is more conspicuous in thin section. For comparison, the combined amounts of $\mathrm{Al}_{2} \mathrm{O}_{3}, \mathrm{Fe}_{2} \mathrm{O}_{3}$, and $\mathrm{SiO}_{2}$ in analyzed samples of massive gray limestone from the lower member of the Natchez Pass averages only a little over 0.1 percent. The calcitic nature of the impure carbonate rocks in the lower part of the upper member is indicated by the relatively low $\mathrm{MgO}$ content of $0.5-0.6$ percent of the two analyzed samples.

The section of the Natchez Pass Formation represented by scattered and incomplete exposures in the northwestem and high, northern parts of the Humboldt Range is generally similar to that in the southern part of the range. Two members of the formation that seem to correspond to those established farther south in the range are recognized. The lower member, however, is composed entirely of massive carbonate rock and thereby differs from the lower member in the southern part of the range because it lacks volcanic and terrigenous clastic units and is much thinner. Above the highest beds of dark laminated cherty limestone included in the Prida Formation, the massive carbonate rocks that con- 
stitute the lower member of the Natchez Pass thin to only a few hundred feet in their northwesternmost exposures. The very thick bedded, or even unbedded, character of the lower Natchez Pass results in prominent cliffforming exposures that commonly exhibit cavernous weathering.

Where the lower member forms the prominent cliffs at the head of Congress Canyon, it is essentially a single bed about 600 feet thick that dips gently westward. The lower member is also represented in the cliffs on the east flank of Star Peak (fig. 4), which from a distance might be mistaken as the northward extension of the clifflike exposure in Congress Canyon. Actually, the two exposures are in different structural blocks; moreover, the steep face of the Star Peak cliffs, instead of exposing a section of the lower member, roughly parallels the bedding of steeply inclined Natchez Pass and Prida strata that have been bent sharply downward from the equivalent nearly flat lying beds exposed above the cliffs on Star Peak. This abrupt downfold is thought to have resulted from eastward overriding on the Tehama reverse fault, which is present at depth but is truncated by the younger, Santa Clara and American basin normal faults, whose traces merge along the foot of the cliffs. Above these cliffs, the relatively undisturbed lower member of the Natchez Pass on Star Peak is about 400 feet thick and forms conspicuous massive outcrops that encircle the summit of Star Peak and the high range crest to the southwest. Farther north, similar cliffy exposures of the lower member form the summit of Santa Clara peak and cap the ridge to the north on the west side of the Santa Clara fault. In the superficially similar belt of craggy outcrops along the trace of the Tehama fault, however, the rock is a tectonic breccia formed largely of material from the upper member of the Prida Formation, though it may include some material from the Natchez Pass toward the north end of this fault zone, where it passes under the alluvial fill of the Humboldt River valley.

Along the west front of the range, between Panther and Buffalo Canyons and west of the Eldorado fault, the lower member of the Natchez Pass Formation is again distinguished by its conspicuous massive character and contrasts with the more thinly bedded and more easily eroded adjacent parts of the Star Peak Group. In this outcrop belt, the thickness of the lower member is as little as 200 feet, a minimum for the exposures of this unit in the Humboldt Range.

The composition of the lower member of the Natchez Pass in the northwestern and high, northern parts of the Humboldt Range is mainly limestone; ullike in the exposures farther south in the range, dolomite is not present in sufficient amounts to be readily recognized in the field. The limestone is massive and homogeneous throughout. It weathers a medium gray, but in most places it is much broken and intricately veined with white calcite. Weathering of this vein material commonly imparts a red stain to the outcrops. Viewed microscopically, the limestone is featureless and has a medium- to coarse-grained granoblastic texture. On weathered or sawn surfaces, however, patches of crystalline white calcite can in some places be recognized as recrystallized coarse-grained shell fragments and echinodermal debris. "Rapid rock" chemical analyses of samples from three different levels within the lower member on the ridge north of Panther Canyon indicate the high degree of purity of this carbonate rock. Combined percentages of $\mathrm{CaO}, \mathrm{MgO}$, and $\mathrm{CO}_{2}$ range from 98.7 to 99.3 percent. The $\mathrm{MgO}$ content for two of these samples is less than 1 percent; for the other sample, in which clusters of secondary dolomite euhedra are evident in thin section, it is 4.3 percent. The principal noncarbonate components are silica and water.

The upper member of the Natchez Pass Formation is only partly represented in the northern part of the main range. Incomplete sections of its lower part overlie the massive limestones of the lower member in three places: along the edge of the range from Panther Canyon north to the Standard mine area, at the head of Congress Canyon, and at Star Peak and southwestward for about 2 miles along the crest of the range. Like the lower part of the upper member in the southern Humboldt Range, these rocks are mainly relatively impure and nonresistant limestone that is evenly stratified, thin to thick bedded, and brown weathering. In the higher parts of the range they tend to form poor outcrops and smooth soil-covered slopes. The most complete section forms the summit of Star Peak, where about 500 feet of impure limestone describes a shallow synclinal fold and grades upward into about 100 feet of massive thickbedded gray limestone that caps the highest part of the peak. This transition from nonresistant impure limestone upward into massive gray limestone presumably corresponds to that which takes place within the upper Natchez Pass in the southern part of the range. If so, the thickness of the impure limestone unit that forms the lower part of the upper member is about the same in both parts of the range, as shown on plate 2 .

The impure limestone that forms most of the lower part of the upper member in the northern part of the range is closely similar in texture and composition to the corresponding part of the section farther south. On fresh surfaces it is medium gray or olive gray with irregular streaks and mottles of yellowish brown. Bivalve and gastropod shell fragments, along with echinodermal debris, commonly form a conspicuous proportion of the rock but generally are not so abundant as 
to form a selfsupporting detrital framework. The matrix is finely crystalline calcite with very subordinate quartz silt. Subtle grain-size differences between discontinuous laminae less than a tenth of a millimeter in thickness impart a faint lamination to the matrix calcite in some thin sections. The sporadically distributed quartz slit in these samples generally corresponds in grain size to the calcite grains of the lamina in which they occur, which suggests that both the calcite and the quartz were deposited as detrital silt-size grains and that the limestone is a calcilutite rather than a recrystallized micrite. In three chemically analyzed samples from the ridge north of Panther Canyon, the amount of $\mathrm{SiO}_{2}$ ranges from 4 to 11 percent and varies proportionally with the $\mathrm{Al}_{2} \mathrm{O}_{3}$ content, which ranges from 0.8 to 1.6 percent. Ferric oxide pseudomorphs after finegrained pyrite cubes are conspicuous in most thin sections; combined values of $\mathrm{FeO}$ and $\mathrm{Fe}_{2} \mathrm{O}_{3}$ range from 0.5 to 1.0 percent. The $\mathrm{MgO}$ content ranges from 0.4 to 0.8 percent.

Discontinuous thick beds of grayish-red chert pebbles in a limestone matrix are a characteristic, though minor, constituent near the base of the upper member in all its isolated exposures in the northern part of the range. Also, in contrast with the same part of the section in the southern part of the range, minor amounts of amygdaloidal mafic metavolcanic rocks and some calcareous siltstone are present in the float from the poorly exposed sections at Star Peak and above the Congress Canyon cliffs.

The highest part of the upper member of the Natchez Pass is represented by a few hundred feet of massive gray limestone that underlies the Grass Valley Formation for several miles along the northwest flank of the range and forms the sole of the Humboldt City thrust plate. These limestones are much contorted, sheared, and recrystallized, and they are extensively silicified, probably by hydrothermal activity, particularly toward the south end of their outcrop belt, near the Standard mine.

The third general outcrop area of the Natchez Pass Formation in the Humboldt Range is in the Mill City hills that form the northeastern tip of the range. Here the Natchez Pass occupies the axial region of a major overturned syncline and is correspondingly much contorted and broken. East of Nevada Highway 50 where it crosses the Mill City hills, further disruption of the section has evidently resulted from local landsliding. Despite these complications, a complete section of the Natchez Pass seems to intervene between the exposures of the Prida and Grass Valley Formations, but the character of the formation differs sufficiently from that of the Natchez Pass elsewhere in the range that the same criteria for subdivision into members cannot be utilized. The bulk of the section is thick and very thick bedded massive recrystallized dolomite and limestone interrupted near the middle by a conspicuous unit of coarseand fine-grained siliceous clastic rocks about 400 feet thick. Within the Natchez Pass below this clastic unit is roughly 1,000 feet of massive gray crystalline dolomite and limestone, and above it, as estimated from the geologic map, is at least several hundred feet of thickbedded gray limestone intercalated with massive buffweathering coarsely crystalline dolomite.

Along the south edge of the prominent hill east of State Highway 50, the clastic unit consists of thick and very thick beds of siliceous chert-pebble-and-cobble conglomerate interlayered with siliceous quartz-chert sandstone, argillite, and calcareous siltstone. Weathering of the more argillaceous and calcareous beds produces a distinctive moderate-reddish-brown (about $10 R \quad 5 / 6$ ) soil that contrasts strongly with the drab color of the adjacent weathered slopes underlain by massive carbonate rocks. The limited exposure of this clastic unit on the west side of Highway 50 is equally thick but lacks siliceous clastic rocks coarser grained than sandstone and contains correspondingly more interbedded calcareous siltstone and impure limestone, some of which includes abundant shell fragments. This apparent trend for the clastic unit to become more calcareous and to contain increasingly fine-grained siliceous clastic material westward can be observed for only about 2 miles along the strike and hence may be fortuitous, but lateral gradation is at least suggested between this clastic unit and the impure, somewhat silty limestone that forms the lower part of the upper member of the Natchez Pass at Star Peak and elsewhere in the main Humboldt Range.

FOSSILS AND AGE

Identifiable age-diagnostic fossils are scarce in the Natchez Pass Formation despite the prevalence in it of shelly detrital material as a rock-forming constituent. The fossils on which the age of the Natchez Pass is based have been described and illustrated in an earlier paper (Silberling, 1961) and are therefore discussed only briefly here.

The characteristic lower Karnian ammonite Trachyceras s.s., has been found about 400 feet above the base of the formation in the northern East Range, and poorly preserved specimens tentatively assigned to this genus and subgenus also occur in limestone intercalated with volcanic rocks several hundred feet below the top of the lower member of the Natchez Pass southeast of Buffalo Mountain at the south end of the Humboldt Range (USGS Mesozoic loc. M657). As upper Middle Triassic fossils occur in the Prida Formation just below 
the Natchez Pass in both the southern and the northeastern parts of the Humboldt Range, strata of both latest Middle Triassic and early Late Triassic age are probably included in the lower part of the Natchez Pass in these areas. (See fig. 3.) In the northwestern part of the Humboldt Range, however, where lowermost Upper Triassic fossils occur in the underlying Prida Formation, the Natchez Pass must be entirely Late Triassic in age.

A large marine invertebrate fauna, consisting of wellpreserved natural molds in partially leached calcareous siltstone, was collected near the stratigraphic base of the siliceous clastic unit that intervenes within the carbonate section of the Natchez Pass Formation in the Mill City hills (USGS Mesozoic loc. M265). Among a variety of pelecypods and cephalopods, the ammonites Paratropites cf. $P$. sulcatus (Calcara, of Gemmellaro) and Spirogmoceras shastense (Smith) and the pelecypod Septocardia? are represented. These two ammonite genera are characteristically late Kamian in age, and pelecypods tentatively grouped under the name Septocardia are widely distributed in the Upper Triassic of Nevada and other regions. The same two species of ammonites have recently been found several hundred feet below a fauna characteristic of the Tropites dilleri Zone on Vancouver Island, British Columbia (Givens and Susuki, 1963), and they may therefore be indicative of the oldest part of late Karnian time. Several of the pelecypods that occur in the siliceous clastic unit of the Natchez Pass in the Mill City hills (Septocardia?, Alectryonia, and Placunopsis) can also be recognized among the shelly debris in the impure limestone unit that forms the lower part of the upper member of the Natchez Pass in the southeastern part of the Humboldt Range. This faunal similarity lends support to the suggested lateral equivalence of these two lithologically distinctive units within the Natchez Pass Formation in different parts of the Humboldt Range, but definite correlation on the basis of these long-ranging genera is unwarranted.

On the north side of Humboldt Canyon (USGS Mesozoic loc. M1142), fragments of the pelecypod Halobia occur in the highest beds of the Natchez Pass Formation; these beds consist of a few feet of impure limestone transitional into the overlying Grass Valley Formation. These specimens have the morphologic features of such species as $H$. superba and $H$. ornatissima that are characteristic of late Karnian strata.

\section{PALEOGEOGRAPHIC INTERPRETATION OF THE STAR PEAK GROUP}

Exposures of the Star Peak Group are scattered along nearly the full length of the Humboldt Range, and a section may thus be reconstructed, as shown on plate 2 , that illustrates the lateral variation of these rocks in a structurally continuous block that is more than 30 miles long in a north-south direction. Some degree of east-west control on the lateral changes apparent in the Humboldt Range section is provided by comparison with the other principal exposures of the Star Peak Group farther east, in the northern East Range, northern Stillwater Range, and southwestern Tobin Range.

Several different lateral relationships among these rocks can be selected as having especial paleogeographic significance. These are: (1) the lateral variation of the basal part of the Star Peak Group; (2) the interrelation between the massive carbonate rocks of the lower member of the Natchez Pass Formation and the thinbedded cherty limestone and dolomite of the upper member of the Prida Formation; (3) the relationship between volcanic and carbonate rocks in the lower member of the Natchez Pass Formation; and (4) the regional relations of the upper member of the Natchez Pass Formation.

lateral Variation at THE base of the star PEak group

Upper Anisian ammonite faunas of the Gymnotoceras rotelliformis, $G$. meeki or $G$. occidentalis Zones occur in all of the principal outcrop areas of the Star Peak Group, and as these zones occupy 100 feet or less of section, they provide a useful datum below which variations in the basal part of the Star Peak can be compared from place to place. The greatest amount of Star Peak deposition predating these upper Anisian zones took place in the northern Humboldt Range, where as much as 700-800 feet of the Star Peak is of Spathian (latest Early Triassic), early Anisian, and middle Anisian age. Impure calcareous rocks of the lower member of the Prida Formation make up more than 400 feet of this thickness. In the southern part of the Humboldt Range, less than 200 feet of unfossiliferous strata, roughly divided between the lower and middle members of the Prida, underlie the Gymnotoceras rotelliformis Zone, and faunas older than late Anisian are not known to occur. The Prida below the upper Anisian ammonite zones in the northern East Range and in the northern Stillwater Range near McKinney Pass is generally similar in composition and thickness to that in the southeastem part of the Humboldt Range. Still farther east, in the southwestern Tobin Range, the Prida is greatly thinned and is represented locally by only a few feet of terrigenous clastics and calcareous sandstone beneath massive carbonate rocks of the Natchez Pass Formation. Here, poorly preserved upper Anisian ammonites occur in the impure calcareous rocks in the basal few tens of feet of the Star Peak Group. On a regional scale, the base of the Star Peak Group is thus generally 
transgressive southward and eastward away from the northern. Humboldt Range.

For the most part, the eroded surface on which the Star Peak Group was deposited had only minor topographic relief, as evidenced by the basal clastic unit of the Prida Formation, which generally contains clasts no larger than pebble size and does not vary in thickness by more than a few tens of feet. In the Humboldt Range, however, some large-scale local topographic irregularities are apparent and evidently have an important genetic relationship to the mineral deposits of the area.

As described previously, abrupt lateral variations in the thickness and composition of the lower member of the Prida Formation in the northern part of the Humboldt Range delineate two distinet basement highs which rose several hundred feet above the adjacent pre-Star Peak erosional surface (fig. 9). The more southern of these, the so-called Arizona basement high, has the shape of an elongate ridge trending somewhat west of north through the Arizona mine area, and it apparently plunges northward toward the forks of Straight Canyon. "Bed-vein" silver deposits (Cameron, 1939, p. 594) like those of the Arizona, Inskip, and Wheeler mines in the lower part of the Prida Formation are apparently localized along the trend of this ridge. Moreover, the position and trend of the Arizona basement high closely coincide with those of the Koipato rhyolite porphyry intrusive rocks that form a string of disconnected exposures from Straight Canyon south to Cottonwood Canyon. In most places, faults separate these silicic intrusive bodies within the Koipato from the adjacent strata of the Star Peak Group; but along the east side of the large exposure of rhyolite porphyry at the head of Peru and Jackson Canyons, small patches of basal Prida Formation rest despositionally on the porphyry, and about half a mile south of the Wheeler mine, the basal Prida is in depositional contact with a small exposure of rhyolite porphyry. Hence, although previously considered of late Jurassic or early Cretaceous age (Cameron, 1939 , p. 584), these rhyolite porphyry instrusives clearly predate the Star Peak Group (Wallace and others, 1960).

The Star-Humboldt basement high in the northwestern part of the range is disrupted by several large-scale faults that obscure its configuration. Lateral changes in the thickness of the lower part of the Prida Formation suggest that the east flank of this basement high trends about north-south, roughly on strike with the elongation of the Arizona basement high, but the position of the other sides of the high is poorly controlled. The Star-Humboldt basement high is evidently broader and areally more extensive than the Arizona high. Like the Arizona high, its location coincides with that of a cluster of rhyolite porphyry intrusives within the Koipato that are depositionally overlain by the Star Peak Group; no other intrusive rocks within the Koipato have been found in the northern Humboldt Range north of Unionville. The Sheba and De Soto mines, which were bonanza silver deposits similar in nature and stratigraphic setting to those of the Arizona group of mines, are in the lower part of the Prida Formation in Star Canyon on the east flank of the Star-Humboldt basement high where the lower part of the Prida is partly cut out against the high. The nearest extensive exposures of Koipato rhyolite porphyry are about $1 \frac{1}{2}$ miles west of the Sheba and De Soto mines. However, Cameron (1939, p. 602 and footnote) mentioned that the Koipato rhyolite which underlies the basal Prida in the workings of the Sheba mine resembles "granite" porphyry, and he recognized that these porphyrylike rocks are part of the Koipato because of their apparently depositional contact with the overlying basal clastics of the Prida and the absence of contact effects in the nearby calcareous rocks of the Prida Formation.

On Black Ridge, in the southern part of the Humboldt Range, the extreme thinning of the Prida Formation might be due to a preexisting topographic high having accentuated the more general southeastward thimning of the Prida during regional transgression. Here, thinning of the Prida is again associated geographically with Koipato rhyolite porphyry int rusions in the underlying rocks, and the silver deposits of the Relief mine occur in the Prida Formation.

The coincidence in location of topographic highs on the pre-Star Peak surface, intrusive rocks within the Koipato Group, and silver deposits in the basal part of the Star Peak Group strongly suggest a genetic relationship between these three features. The Koipato intrusive rocks, being the oldest of the three, are thought to be the controlling feature. Evidently intrusion of these rhyolite porphyry feeder dikes and related rocks into the Koipato volcanic pile locally affected its resistance to erosion so that the intruded parts of the Koipato were left as topographic highs following the period of tilting or gentle folding and erosion that preceded deposition of the Star Peak Group. The well-

FIgURe 9.-Isopachs of pre-upper Anisian strata at the base of the Star Peak Group plotted on the bedrock outline of the Humboldt Range. Areas of minimum pre-upper Anisian thickness delineate topographic highs on the pre-Star Peak erosional surface of the Koipato Group and coincide geographically with the location of intrusive rocks within the Koipato Group. Traces of the depositional contact between the Koipato and Star Peak Groups are shown to indicate where in the range the basal part of the Star Peak is exposed, and to indicate the control for isopaching its thickness. 
PALEOGEOGRAPHIC INTERPRETATION OF THE STAR PEAK GROUP

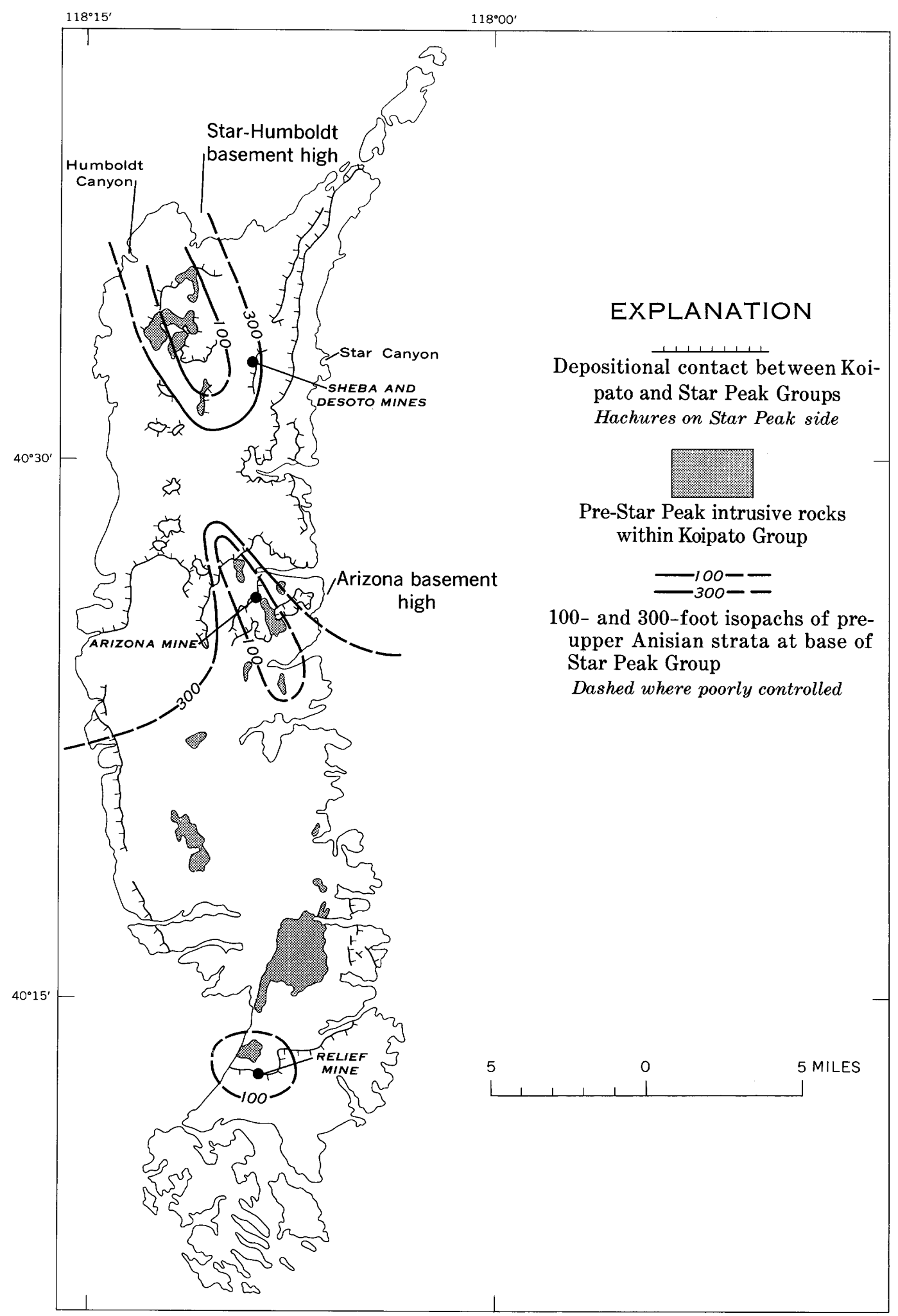


defined linear shape of the Arizona basement high seems to relate to the subcrop pattern of the Koipato rhyolite porphyry on the pre-Star Peak surface, but the unique occurrence of mafic volcanic rocks in the basal Prida Formation along the west side of this basement high could also indicate that its shape and topographic relief results in part from block faulting during the initial phase of Star Peak deposition. However, pre-Star Peak faulting within the Rochester Rhyolite would be difficult to demonstrate here because of the heterogeneous, rapidly interlensing lithologic character of these Koipato volcanic rocks, and such faults were not recognized in the course of geologic mapping. Long after the Star Peak Group was deposited, presumably during the time of late Mesozoic intrusive activity, manifested mainly by the granite exposed in the vicinity of Rocky Canyon, the Koipato intrusive rocks evidently served as a source or channel for mineralizing fluids that formed the "bed-vein," stockwork, and replacement silver deposits in the lowest calcareous rocks of the Star Peak Group where they surmount the preexisting basement highs associated with the Koipato intrusive rocks.

facies Relation between the PRida AND NATChez PASS FORMATIONS

The upper member of the Prida Formation and the lower member of the Natchez Pass Formation in the Humboldt Range represent a striking change of facies within the Star Peak Group. As already described, the distinctive dark laminated cherty limestone and dolomite of the upper Prida has the form of a thick wedge whose lateral decrease in thickness corresponds to an increase in thickness of the overlying massive carbonate rocks of the lower Natchez Pass (pl. 2). From its northwesternmost exposures in the Humboldt Range, where its thickness may exceed 2,000 feet, the upper Prida thins southward within the Humboldt Range to a wedge edge; to the east, in the northern East Range and near McKinney Pass in the northern Stillwater Range, it thins to only several tens of feet; and in the easternmost section of the Star Peak Group, in the southwestern Tobin Range, it is absent. Inversely, the lower Natchez Pass thickens from only a few hundred feet in the high, northern part of the Humboldt Range to about 1,000 fcet toward the northeast in the Mill City hills and to about 1,500 feet toward the south in the southern Humboldt Range (where it contains much volcanic rock besides the more characteristic massive organic-detrital carbonate rock) ; in the ranges to the east of the Humboldt Range, the part of the Natchez Pass Formation corresponding to the lower member is at least several hundred feet thick.

Partial lateral equivalence of the upper Prida and lower Natchez Pass is demonstrated by their strati- graphic relation to the widespread upper Anisian ammonite zones, which directly underlie the upper member of the Prida, wherever present, or the lower member of the Natchez Pass, where the upper Prida facies is absent, as in the Tobin Range. Within the upper Prida and lower Natchez Pass faunal evidence for contemporaneity is indecisive, but the available faunas strongly suggest that lower Karnian rocks are present in the higher parts of both units in different places. Thick interbeds of massive organic-detrital carbonate rock like that of the lower Natchez Pass are conspicuous in the higher parts of the upper Prida in the Humboldt Range, and though the discontinuity of exposures prevents direct tracing of these beds into the Natchez Pass Formation, they probably represent interfingering of the two facies as shown diagrammatically on plate 2 .

The change in facies between the dark, laminated carbonate rocks of the upper member of the Prida and the massive carbonate rocks of the lower member of the Natchez Pass thus takes place within a largely correlative package of Ladinian and lower Karnian strata that thickens from about 1,000 feet on the southeast to more than 2,000 feet to the northwest; and the greatest total thickness corresponds in location to the thickest accumulation of the dark laminated carbonate facies.

Several lines of evidence indicate that the upper Prida is an offshore, relatively deepwater deposit in comparison with the lower Natchez Pass. The lamination and even, thin parting characteristic of the upper Prida points to quiet-water deposition, as do the intercalated chert layers formed of fine-grained biogenic silica. A foul-bottom depositional environment is suggested by the dark color of these rocks and by their lack of a shelly bottom fauna. None of the larger marine invertebrates that occur sporadically as fossils in these rocks is known to have been a bottom dweller. Although quietwater and foul-bottom conditions are not necessarily restricted to deep basinal environments, an appreciable depth of water is implied by the existence of a paleoslope sufficiently steep to have induced slumping within the upper Prida and the disruptive emplacement in them of coarse sedimentary breccias of massive carbonate rocks. A number of the laterally persistent interbeds of massive organic-detrital carbonate rocks within the dark laminated cherty limestone of the upper Prida were carefully examined for graded bedding or any other features indicative of turbidity current deposition, but nothing conclusive was found.

The depositional environment inferred for the featureless massive medium-gray limestone and dolomite of the lower member of the Natchez Pass is that of a progressively subsiding carbonate bank on which a varied bottom fauna of echinoderms, corals, brachio- 
pods, and mollusks flourished under turbulent shallowwater marine conditions. Although the remains of sediment-binding organisms form a part of the recognizable biogenic calcareous detritus in the lower Natchez Pass, in no place were they seen to form a selfsupporting reeflike framework. Moreover, the progressive and gradual nature of the thickness changes undergone by the lower Natchez Pass precludes the interpretation of any major part of it as an organic reef. This calcareous sand deposit must have accumulated on shallow banks bordering the deeper, more offshore depositional site of the upper Prida on the south and east. But through time, sedimentation evidently exceeded the rate of regional subsidence, and the shallow-water bank deposits of the lower Natchez Pass were gradually built northwestward over previously deposited parts of the upper Prida in a regressive fashion.

The depositional relationship between the upper member of the Prida Formation and the lower member of the Natchez Pass, at least in its broader features, resembles the basinward-shoreward facies changes recognized in some other marine carbonate deposits. Several parts of the lower and middle Paleozoic section of eastcentral Nevada undergo lateral westward and, in general, basinward change from massive dolomitic carbonate rock to more thinly bedded impure limestone that is commonly laminated and chert bearing. The abrupt facies relations described by Winterer and Murphy (1960) between parts of the Roberts Mountains and Lone Mountain Formations in the Silurian part of this section is particularly pertinent. In composition, environmental interpretation, and spatial relationships these Silurian facies are generally similar to those represented by the upper Prida and lower Natchez Pass. As described by Winterer and Murphy (1960) the finegrained laminated calcareous rocks of the Roberts Mountains Formation contain a higher proportion of terrigenous clastic material than is found in the upper Prida; the eastward transition of these rocks into massive carbonate rock is more abrupt and is attended by more conspicuous interfingering of sedimentary breccias and graded calcarenites; and organic reefs are thought to be mainly responsible for the thick accumulation of the massive Lone Mountain Dolomite. But these differences in fact or interpretation between the relations of the Roberts Mountains-Lone Mountain facies and the upper Prida-lower Natchez Pass facies are more in degree than in kind, and they do not negate the general paleogeographic analogy.

Also similar to the upper Prida-lower Natchez Pass relationship are some of the basinward-shelfward facies changes in the Permian rocks of west Texas and New Mexico as described by King $(1942,1948,1962)$ and further elucidated by Newell, Rigby, Fischer, Whiteman, Hickox, and Bradley (1953). Especially analogous to the lower member of the Natchez Pass is the Victorio Peak Limestone, which is interpreted as a marginal bank deposit of organic-detrital carbonate sand that interfingers with, and was built progressively basinward out over, the partly correlative black cherty laminated Bone Spring Limestone deposited in the marginal parts of the Delaware Basin.

\section{RELATIONSHIP BETWEEN VOLCANIC AND CARBONATE ROCKS IN THE} NATCHEZ PASS FORMATION

Volcanic rocks form only a small proportion of the Star Peak Group in the Humboldt Range except in its southwesternmost exposures, where mafic breccias, flows, and tuffs supplant, by abrupt interfingering, most of the massive carbonate rocks of the lower member of the Natchez Pass Formation. The stratigraphic relations of these volcanic rocks are well displayed eastward across Black Ridge and can be interpolated northward, but to the west and south they cannot be determined owing to the absence of outcrops in these directions.

The paleogeographic significance of this volcanic pile in the lower Natchez Pass of the southern Humboldt Range can be interpreted in two ways. It may represent localized recurrent volcanism along what was the shallow southern margin of Star Peak deposition where massive organic-detrital carbonate rock of the lower Natchez Pass was the normal sediment being deposited. Or it may have formed a submarine rise, perhaps emergent at times, on which shallow-water carbonate deposition took place in an area that was relatively offshore with respect to a generally north-south-trending shoreline. The increasing proportion of volcanics in the lower Natchez Pass southward in the same direction that transgression took place at the base of the Star Peak Group in the Humboldt Range tends to support the first of these interpretations. The alternative interpretation is suggested, however, by the abnormally great thickness of the lower Natchez Pass carbonate rocks adjacent to this volcanic pile as compared with their thickness at other places where they overlie a similar section of the Prida Formation but lack thick intercalations of volcanic rocks.

The Natchez Pass Formation exposed to the east of the southern part of the Humboldt Range-near McKinney Pass in the northern Stillwater Range and in the Tobin Range-is closely similar in composition to that which crops out along the southeast edge of the Humboldt Range. The volcanic rocks are generally restricted to a single unit that forms only the uppermost hundred feet or so of the lower member. Recent field studies by R. C. Speed (oral commun., 1963), however, have shown that the area mapped as intrusive rock by 
Muller, Ferguson, and Roberts (1951) on the steep east face of the Stillwater Range-from about 10 miles south of McKinney Pass south to Cottonwood Canyonis underlain, instead, mainly by rocks of the Koipato and Star Peak Groups. The Natchez Pass exposed here was found by Speed to include a much larger proportion of mafic volcanic rocks than it does several miles farther north. Hence, in the northern part of the Stillwater Range, as in the Humboldt Range, volcanic rocks within the Natchez Pass evidently thicken abruptly to the south. Unfortunately, as in the Humboldt Range, this change takes place in the southernmost outcrops of the Natchez Pass, and the nature of the section still farther south cannot be determined. But whether the southward increase in volcanic rocks seen in the Humboldt and Stillwater Ranges represents transition of the Natchez Pass Formation into a widespread volcanic unit, or simply the presence of localized, randomly distributed volcanic piles within a predominantly calcareous section, it constitutes a facies change whose boundary trends northwest-southeast, or about at right angles to the general north-south or northeast-southwest trend of the sedimentary facies-change boundaries within the Star Peak Group that cannot be related to vulcanism. Much of the north to south change from relatively deep-water to shallow-water carbonate deposition displayed by the lateral interrelation between the upper Prida and lower Natchez Pass in the Humboldt Range may therefore relate to the shoaling effect resulting from contemporaneous volcanic activity rather than to the paleoslope controlled by regional subsidence and by the erosional surface of the older rocks over which Star Peak deposition transgressed.

REgIONAL RELATIONS OF THE UPPER MEMBER OF THE NATCHEZ PASS FORMATION

Compared with the underlying parts of the Star Peak Group, the upper member of the Natchez Pass Formation is remarkably consistent in composition throughout the southern part of its regional extent. It is generally the same in the Tobin Range as it is in the southern part of the Humboldt Range; in the northern Stillwater Range it is the same in composition but is thinner. At all these places it rests on volcanic rocks at the top of the lower member of the Natchez Pass, and its lower contact is sharp without noticeable reworking of volcanic material upward into the upper member.

In the high, northern part of the Humboldt Range, the upper member of the Natchez Pass seems to be closely similar to that farther south in thickness and composition, but the incomplete nature of the exposures precludes positive comparison. Farther northeast, in the Mill City hills, however, the corresponding part of the section is different, though it has been suggested in the description of these rocks that the siliceous clastic unit within the Natchez Pass here equates with the impure limestone that forms the lower part of the upper Natchez Pass farther south. If so, an abrupt change in lithology would again mark the base of the member.

Still farther northeast, in the type area of the Natchez Pass in the northern East Range, this chain of lithologic correlations becomes decidedly weaker. Siliceous clastic rocks like those intercalcated with the Natchez Pass carbonate rocks in the Mill City hills here form one or more units as much as a few hundred feet in total thickness in the upper part of the formation, but between them and the overlying Grass Valley Formation is apparently only a few hundred feet of carbonate rock. Assuming a direct correlation of these siliceous clastic rocks with those in the Mill City hills, evaluation of the apparent reduction in thickness of the overlying Natchez Pass carbonate rocks must await more detailed structural and stratigraphic understanding of the East Range exposures. It should be emphasized, moreover, that the greater thickness attributed to the carbonate rocks above the siliceous clastic unit in the northeastern Humboldt Range is little more than a guess and could be seriously in error. Hence, although the upper part of the Natchez Pass in the East Range may relate to that in the Mill City hills, and these rocks may in turn relate to the upper member of the Natchez Pass recognized farther south, positive correlation is not yet possible.

Despite these difficulties in recognizing the upper member in the more northerly outcrops of the Natchez Pass, attention is drawn to the possibility that the upper member disconformably overlies the lower member of the Natchez Pass. This is suggested by the laterally uniform lithologic nature of the upper Natchez Pass in its more southerly exposures and by the sharp contact separating it from the relatively heterogeneous and laterally variable older parts of the Star Peak Group. Furthermore, the faunal evidence is not inconsistent with the existence of a hiatus within the Natchez Pass Formation. The faunas in the lower Natchez Pass and upper Prida that are tentatively dated as earliest Karnian occur only a few hundred feet below the base of the upper member of the Natchez Pass, whereas the late Karnian fauna from the Natchez Pass of the Mill City hills occurs just above the stratigraphic base of the siliceous clastic unit, which may correspond to the base of the upper member. The absence of upper lower Karnian strata may thus be inferred, though biostratigraphic standards in North American are currently inadequate to suggest what proportion of the Karnian this omission might represent. 
The decreasing rate of subsidence suggested by the progressive seaward deposition of the shallow-water carbonate rocks of the lower Natchez Pass out over the upper Prida rocks may have culminated in a brief episode of uplift and emergence prior to deposition of the upper Natchez Pass. Rejuvenation of bordering source lands related to this uplift might then account for the coarse-grained terrigenous clastic sediments that appear in the upper part of the formation in its northeastern exposures in the Humboldt Range and in the northern East Range.

\section{GRASS VALLEY FORMATION}

The Grass Valley Formation of the Humboldt Range agrees in stratigraphic position, composition, and general thickness with the typical exposures of the formation in the northern East Range (Ferguson and others, 1951). In the Humboldt Range, as in the East Range, the greater part of the Grass Valley is dark argillite, slate, and phyllite interlaminated in part with micaceous siltstone or very fine grained sandstone, all of which characteristically weathers to olive gray or a similar color. Subordinate interbedded units of sandstone as much as several tens of feet thick form occasional dark craggy outcrops on the otherwise smooth, rounded slopes underlain by these rocks. Owing to the lithologically repetitious, poorly exposed, unfossiliferous, and structurally complex nature of these rocks, their true thickness and detailed stratigraphic succession is indeterminate.

In the northern part of the Humboldt Range the Grass Valley Formation crops out extensively in the low hills along the northwest flank of the range from the Standard mine area north to Imlay Canyon. Along with the highest beds of the underlying Natchez Pass Formation, the incomplete Grass Valley section here forms the upper plate of the Humboldt City thrust and has overridden older parts of the Star Peak Group. Allowing for unrecognized faults and small-scale folds, probably much more abundant than is evident, a few thousand feet is a reasonable estimate for the exposed thickness of the Grass Valley Formation. At the northeast end of the Mill City hills, a few hundred feet of lowest Grass Valley rocks overlie the Natchez Pass Formation in the axial region of a major overturned syncline.

At the southern tip of the Humboldt Range the Grass Valley Formation underlies most of the Pershing mining district and the low hills bordering the south end of Black Ridge. Although both the lower and upper boundaries of the formation are exposed, an indeterminate amount of the section may be cut out structurally. The minimum estimated thickness is about 2,000 feet. Exposures of the lower part of the Grass Valley Formation wrap conformably around the south-plunging anticlinal nose of Star Peak rocks at the south end of Black Ridge from Packard Flat eastward to Cow Canyon. Farther north along the southeast flank of the range, the Grass Valley has been eroded away, but it is preserved beneath the Cenozoic basalt flow between Dry Gulch and American Canyon, where it appears in the underground workings of the Hillside mine.

Much of the Grass Valley Formation exposed in the Pershing district represents the highest several hundred feet of the formation repeated structurally and is atypical in weathering mainly to shades of red or orange and in having some interbedded calcareous rocks. The color difference between this part of the Grass Valley section and the underlying parts is partly a hydrothermal effect, but it may also reflect some primary compositional difference. On strike with the red- and orangeweathering Grass Valley exposures in the Pershing disstrict are similar pelitic and sandy rocks in the small portion of the West Humboldt Range included within the Buffalo Mountain quadrangle, but the full extent of the Grass Valley in the West Humboldt Range is unknown.

The upper contact of the Grass Valley Formation with the overlying carbonate rocks of the Dun Glen Formation in the Pershing district is gradational; the highest argillaceous and sandy beds of the Grass Valley are calcareous in part and include lenticular beds of limestone. On the geologic map, the upper limit of the Grass Valley is arbitrarily placed at the base of the lowest laterally persistent carbonate unit on each of the different strike ridges where the Grass Valley-Dun Glen transitional contact is exposed. As the main body of Dun Glen carbonate rocks probably bears a complex lateral relation to the similar, discontinuous carbonate beds in the uppermost Grass Valley, the formational boundary as drawn probably varies somewhat in stratigraphic level from place to place.

\section{LITHOLOGIC DESCRIPTION}

Most of the Grass Valley Formation is formed of metapelitic, silty, and sandy rocks that represent the same general source of sediment supply and differ mainly in the degree of sorting and in metamorphic effects. These rocks are largely noncalcareous and lack interbedded carbonate rocks; exceptions are the highest parts of the formation transitional into the overlying Dun Glen Formation. Terrigenous detrital material coarser than medium-grained sand is absent.

The finer grained pelitic and silty rocks make up twothirds or more of the section and include slate, phyllite, argillite, and micaceous siltstone. All these rocks are black, or nearly so, in fresh exposures, but weather 
olive black (5Y 2/1) to light olive gray $(5 Y 6 / 1)$ and greenish gray ( $5 G Y 6 / 1)$. Commonly all these finegrained rock types, which differ mainly in the proportion and grain size of their silt content, are mixed together in the finely broken surface debris at any one place. Siltstone is generally distributed as very thin stringers and laminae through the more pelitic rocks, but locally the section may be predominantly slate or phyllite through several tens of feet or more.

The composition of these fine-grained noncalcareous rocks has not been studied rigorously. „udging from the nature of the interstitial material seen in thin sections of the sandstones in association with them, the original clay content of these pelitic rocks has been entirely recrystallized to sericite and chlorite. This is supported by X-ray diffraction analysis of two samples that characterize the extremes in megascopic appearance among the noncalcareous metapelites in the vicinity of Humboldt Canyon. Despite their difference in appearanceone sample is a lustrous dark-olive-gray slate and the other is a "soft" medium- to light-olive-gray silty argillite - their compositions are about the same. Both of them, according to D. B. Tatlock, are about half quartz, with muscovite and chlorite making up the remainder; their total iron content is about 6 percent. The presence of clay is suggested only in the weathered-appearing argillite and can be attributed to weathering.

Sandstones make up about one-third, or less, of the Grass Valley Formation in the Humboldt Range and are chiefly of two different types characterized as "impure" and "clean." To some extent these are intergradational, but intermediate varieties are scarce, and the two different types seem to represent distinct depositional environments.

The impure sandstone is mainly very fine grainedmost of the quartz grains in the size range from 0.05 $\mathrm{mm}$ (coarse silt) to $0.10 \mathrm{~mm}$ (fine sand). Original argillaceous impurity is represented by interstitial sericitic and chloritic material; the chloritic material imparts an olive-gray or greenish-gray color to fresh surfaces of the rock. The pure sandstones, on the other hand, are medium or fine grained and range from nearly white to medium light gray $(N 6)$ and light brownish gray $(5 Y R 6 / 1)$ on fresh exposures. Characteristically, their unweathered surfaces are speckled by dark-brown aggregates of ferric oxides and calcite. These calcareous patches may amount to 10 percent or more of some samples, but most of the rock is cemented by interlocking overgrowths of the quartz grains. Apart from their differences in grain size and matrix materials, the impure and clean sandstones are much the same in the mineral composition of their silt and sand fractions. Quartz grains are the most abundant and in the coarser size fractions are moderately well rounded. Albite is present in varying amounts that may be as much as about 30 percent but usually are not more than several percent. No potash feldspar is apparent in the thin sections studied. All the sandstones are conspicuously micaceous; detrital flakes of muscovite form at least several percent of the impure sandstone beds and are concentrated on their internal stratification surfaces, giving them a characteristic spangle. Only a few larger grains of biotite are preserved, and these are in different stages of chloritization. Discrete flakes of chlorite, present in minor amounts in some samples, are probably also a detrital constituent. Heavy minerals are abundant, and in the impure sandstones where their grain size is comparable to that of the quartz, they may constitute a few grains out of every hundred counted. The commonest varieties are a distinctive bluish-green tourmaline, zircon, and opaque grains (largely leucoxene?).

Of the two kinds of sandstone, the impure is the more abundant, and in composition and manner of occurrence it is transitional into the siltstone stringers that are pervasively interbedded among the noncalcareous pelitic rocks. Impure sandstone occurs as very thin or thin even beds either interspersed in the dominantly pelitic section or, more characteristically, grouped together in

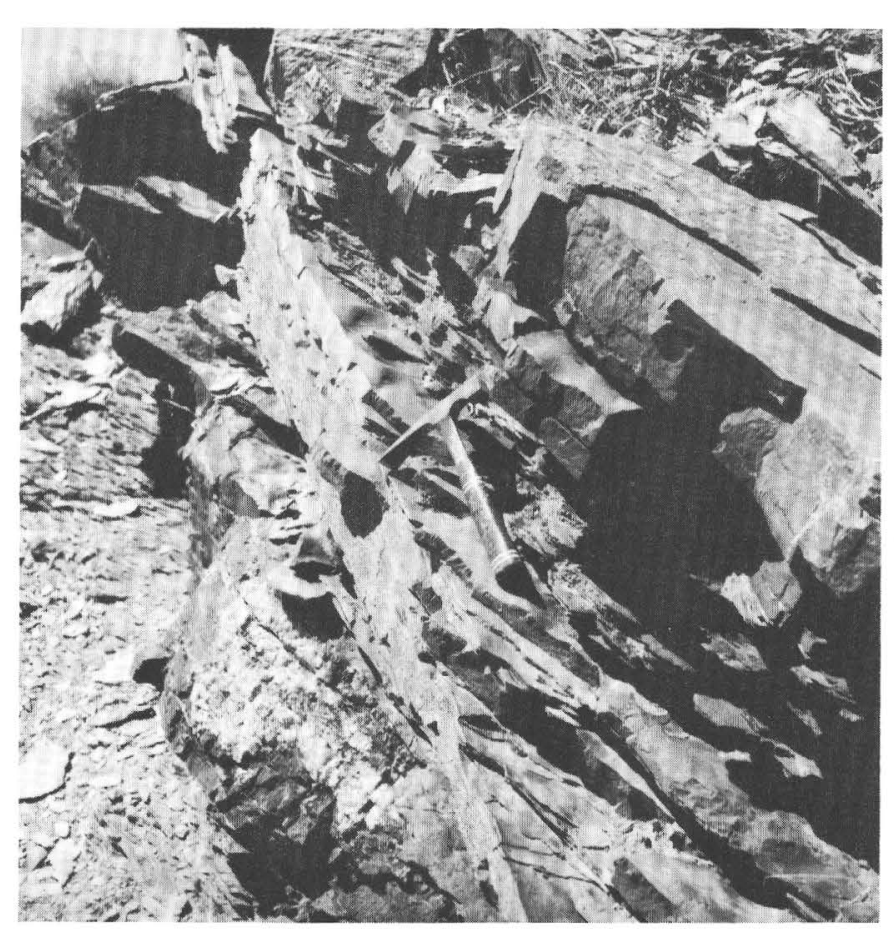

Figure 10.-Very thin and thin-bedded impure sandstone of the Grass Valley Formation on the crest of the northern East Range about 1 mile southeast of Dun Glen Park, characteristic of outcrops of this kind of sandstone in both the northern East Range and in the Humboldt Range. 
sets with pelitic partings between them (fig. 10). These sets range from a few feet to several tens of feet in thickness and apparently are laterally discontinuous. Even where exposures are good, none could be traced laterally for a distance greater than about 10 times its thickness. Both the lower and upper surfaces of the impure sandstone beds are sharply defined, and the beds show no grading. Small-scale current crossbedding is commonly well developed and expressed on the top surfaces of the beds by linguoid ripple marks (fig. 11). No other kinds of ripple marks are found on these beds. The bottom surfaces commonly bear load casts (fig. $12 C$ ). More rarely, the bottom surfaces display a profusion of current-formed sole markings of the drag and impact kind, where these markings have not been obliterated by load casts. These "drag," "brush," "bounce," and "prod" marks are invariably associated with the ripplemarked beds and on any one bed indicate the same current direction as that shown by the ripple marks (fig. 13). Thus, the objects that marked the soft bottom on which the sand was deposited may have been carried by the same currents that transported and rippled the sand. Some of the more unusual kinds of sole markings found on the bottom surfaces of these impure sandstone beds of the Grass Valley were illustrated by Dzułynski and Sanders (1962, text-fig. 4; pl. 10, fig. $A$; and pl. 16, fig. C).

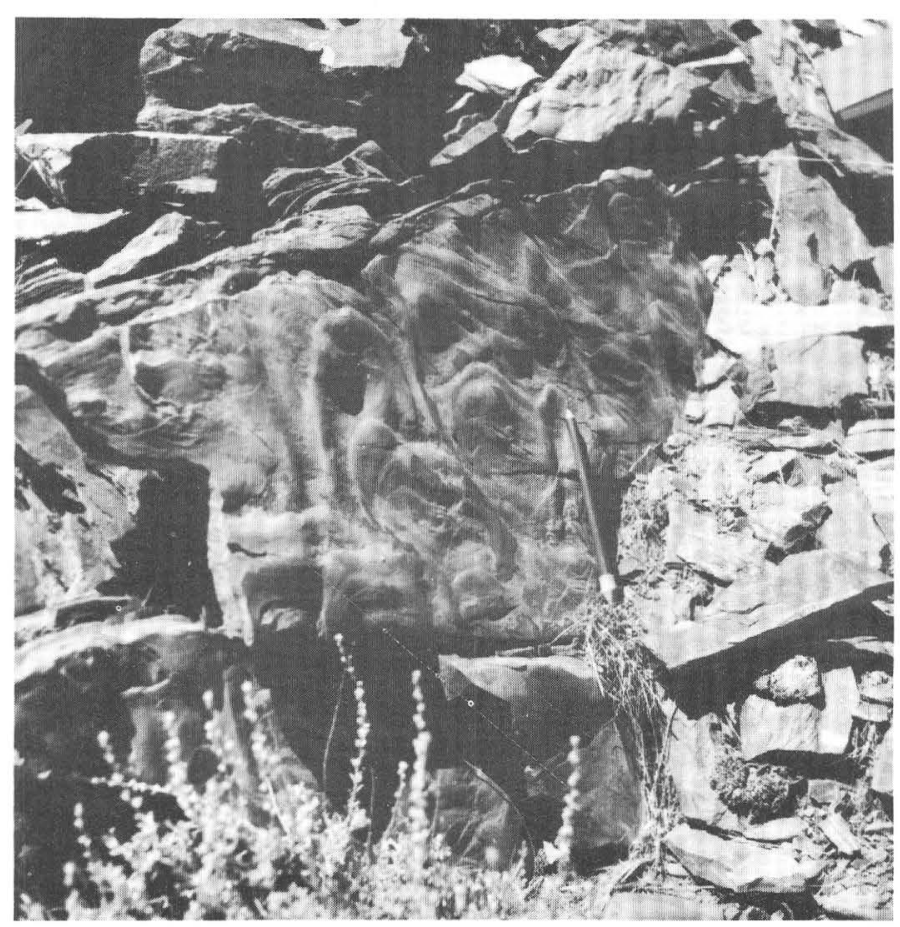

Figure 11.-Linguoid ripple marks on the top surface of an impure sandstone bed in the Grass Valley Formation. Pencil point is in the direction of current. Same locality as figure 10.
The slightly calcareous light-colored clean sandstones occur as widely separated discrete units several feet to several tens of feet thick and are most abundant in the higher parts of the Grass Valley section. Unlike the sets of impure sandstone beds, some units of clean sandstone are laterally persistent. Two of them (possibly the same unit repeated structurally), though only 10 feet or so in average thickness, can be traced for more than 1 mile between Humboldt and Imlay Canyons. The clean sandstones are commonly medium bedded and massive appearing, although some planar lamination is usually present within the beds. Oscillation ripple marks were observed near the mouth of Imlay Canyon and in the Pershing district, where the clean sandstones near the top of the formation are commonly crossbedded. These structures provide some of the top and bottom criteria on which the structural interpretation of the Pershing district is based. Of even greater value for this purpose, because of their more widespread occurrence, are load casts formed on the soles of some clean sandstone beds that are intercalated with pelitic rocks in the highest part of the Grass Valley Formation.

The uppermost part of the Grass Valley Formation is repeated several times in the complexly folded and faulted part of the Pershing district southwest of the Relief fault. These rocks differ in appearance from the main body of the Grass Valley elsewhere in the range. Pelitic rocks predominate, as they do throughout the formation, but their weathering colors are chiefly light shades of orange and red, generally in the range from yellowish gray through grayish orange to pale red. Both brittle-fracturing argillites and slates are represented as well as some "soft" flaky "shale." Interbedded in subordinate amounts are clean pinkish-gray (commonly $5 Y R 7 / 1)$ calcareous sandstone and discontinuous units of limestone. Some of the limestone is in massive gray beds much like those of the overlying Dun Glen Formation; other units are impure and weather light brown, and some are nodular mixtures of gray limestone in brown calcareous sandstone. Marine fossils occur in the stratigraphically higher of these calcareous interyeds.

Although these deformed upper Grass Valley rocks have a rather large outcrop area, their thickness probably amounts to only several hundred feet. In the upright and apparently continuous Grass Valley section southwest of the anticlinal axis that runs through the Hollywood mine area, the transition from the more characteristic dark metapelites and associated sandstones up into the overlying grayish-orange-weathering pelitic rocks with some interbedded limestone takes place about 700 feet below the top of the formation. 
The reason why the pelitic rocks in the Pershing district weather predominantly orange and red, as compared with the dark-olive or greenish-gray color of the pelitic rocks in other parts of the Grass Valley section, is not fully understood from the data at hand. As seen in favorable exposures, such as in mine workings and deep gullies, the orange color results from weathering of originally dark-colored pelite. The few samples of these orange-weathering rocks analysed by $\mathbf{X}$-ray diffraction have kaolin and illite as their principal sheet-structure minerals, whereas the dark-greenish-gray-weathering pelites are chlorite-bearing. Thus, the difference in weathering color may be related to the difference in composition. The chlorite in the dark-weathering pelites, though probably largely recrystallized, must represent some original ferromagnesian constituent such as finegrained detrital chloritic or biotitic material that was either absent or has been altered in the clay-bearing, nonchloritic, light-weathering rocks. Alteration by pervasive hydrothermal activity is a strong possibility, and in places networks of fractures crosscutting the orangeweathered rocks are bordered by bands of red-weathered rock a fraction of an inch wide, clearly indicating the alteration nature of the orange to red color change.

Nevertheless, some primary compositional control of the light-weathering characteristic is suggested by the essentially stratigraphic nature of its boundaries. Where the transition between dark-weathering and lightweathering metapelites is exposed near the Hollywood mine, it roughly parallels bedding, and in the northwestern part of the Pershing district, dark-greenishgray slate and argillite forms a distinct stratigraphic unit at the top of the Grass Valley and separates the orange-weathering rocks below from the overlying Dun Glen Formation. Furthermore, orange and red weathering generally coincides with the calcareous part of the section to which marine fossils are restricted in the Humboldt Range and elsewhere, as in the northern Stillwater Range. It seems unlikely that a difference in depositional environment could explain the presence of clays instead of chlorite in these rocks, and this problem remains unsolved. But orange and red weathering might result from some other minor constituent unique to the marine calcareous part of the section-for example, an iron-bearing carbonate mineral that has been removed by subsequent leaching.

At two different localities in the upper Grass Valley Formation of the Pershing district, flute casts (figs. $12 A, B$ ) were found on the soles of thin or very thin beds of somewhat calcareous, but relatively poorly sorted, sandstone intercalated with orange or red pelitic rocks. These are the only known occurrences of these structures in the formation, and as discussed under paleogeographic interpretation, they were formed by currents different from those that deposited the noncalcareous impure sandstones lower in the section.

In the northwestern part of the Humboldt Range, in the Imlay quadrangle, some slate and slaty siltstone of the Grass Valley Formation along the range front immediately north of Humboldt Canyon weathers redbrown (10R 5/4 and similar shades) and includes stringers of calcareous siltstone and very fine grained calcareous sandstone. By analogy with the stratigraphic level of similar rocks in the southern part of the range, these red-weathering calcareous beds may be near the top of the formation.

Farther south along the northwestern range front, between Humboldt and Johnson Conyons, the Grass Valley rocks in a belt about 2 miles long and as much as onehalf mile wide have been extensively altered, evidently by hydrothermal activity. The eastern boundary of this alteration zone is abrupt and to the north, toward Humboldt Canyon, it apparently coincides with a fault recognized within the Grass Valley Formation. Northward along strike the altered Grass Valley passes into the dark metapelites and sandstones characteristic of most of the formation. Within the altered zone the finer grained parts of the section have been transformed into structureless dense aphanitic rocks that commonly have light-gray and pale-red concentric color banding. In places they are further altered by bleaching and silicification. Sandstone units can be recognized, but the usual metapelitic micaceous and chloritic interstitial material of the sandstone has been altered to ferric oxide and clay.

\section{AGE}

Fossils other than traces of plant remains are unknown in the Grass Valley Formation except in its uppermost beds, which are transitional into the overlying Dun Glen Formation, and these occurrences are treated in the discussion of the Dun Glen Formation.

As upper Karnian fauna occur in the upper part of the underlying Natchez Pass Formation and lower middle Norian faunas characterize the uppermost Grass Valley and the Dun Glen Formation, the age of the

Figure 12.-Sedimentary structures on the bottom surfaces of sandstone slabs from the upper part of the Grass Valley Formation in the Pershing district at the south end of the Humboldt Range. All reduced to one-half natural size. $A$, Flute casts from locality about one-third of a mile northeast of the Hollywood mine. Current direction toward lower left. $B$, Small-scale fute casts from locality on the south side of South Relief Canyon in the central part of sec. 29, T. 27 N., R. 34 E. Current direction toward lower left. C, Load casts from locality about one-tenth of a mile southwest of the Hollywood mine. 

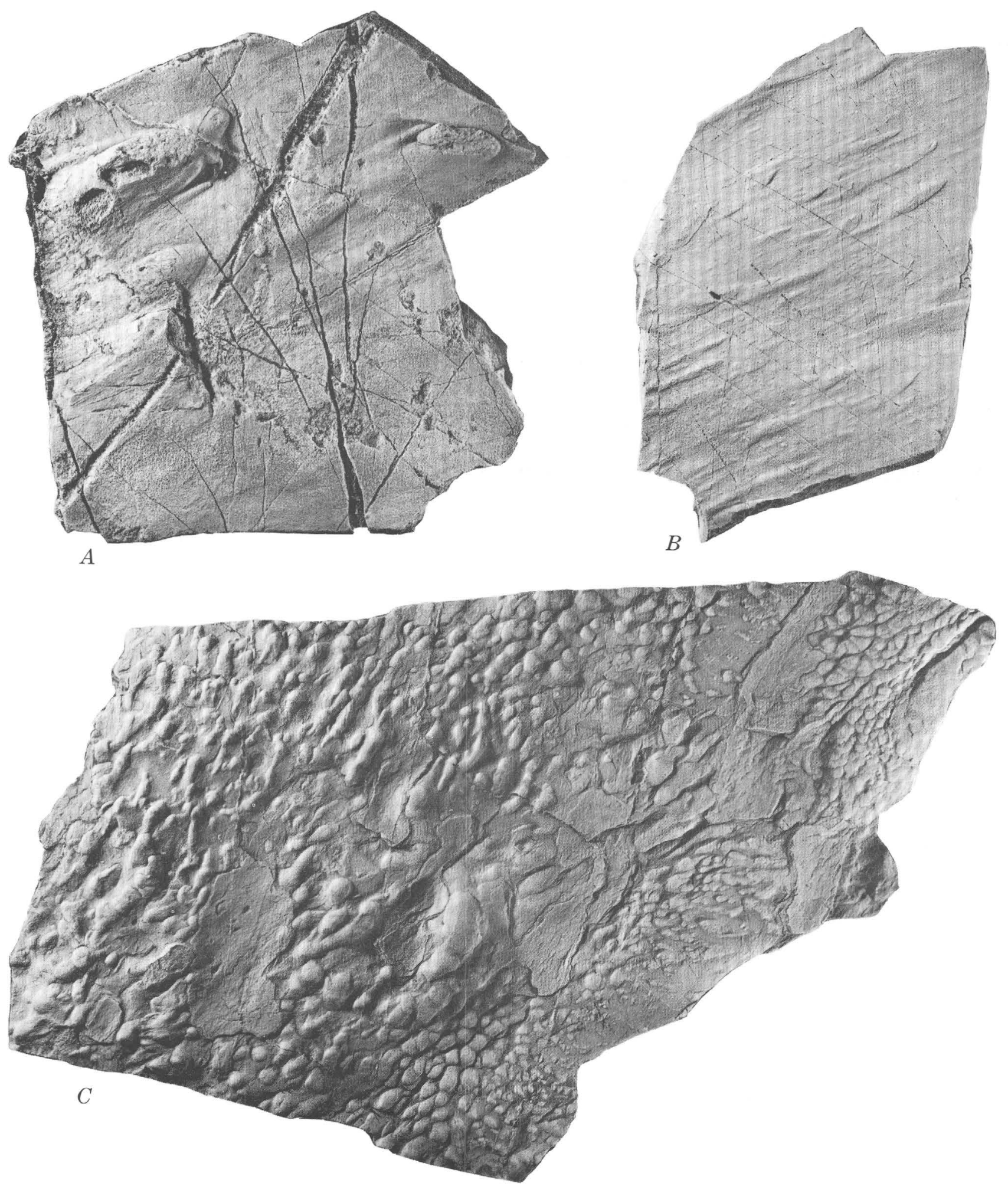
Grass Valley is bracketed between fairly narrow limits. It is mainly early Norian in age, but includes strata of early middle Norian age at its top and may include strata of latest Karnian age at its base. (See fig. 3.)

\section{PALEOGEOGRAPHIC INTERPRETATION}

The paleogeographic interpretation of the Grass Valley Formation has far-reaching significance because it bears on the depositional history of the much larger, lithologically similar body of strata of which it is a part. The Grass Valley forms the base of a thick widespread assemblage composed mainly of fine-grained terrigenous clastic rocks that range from middle Late Triassic to Early Jurassic in age. These rocks, which crop out at a number of places in Pershing County and eastern Humboldt County, overlie the Star Peak Group and form the upper part of the "Winnemucca sequence" of Silberling and Roberts (1962). Some units of carbonate rock, such as the Dun Glen Formation, occur within this predominantly pelitic and sandy assemblage, but even though their thickness may locally amount to several hundred feet or more, they form only a small proportion of the whole.

In the Humboldt Range and the nearby ranges to the east this assemblage is represented by the Grass Valley, Dun Glen, Winnemucca, and Raspberry Formations and some unassigned strata in isolated exposures. Although an uninterrupted sequence of these formations, which belong mainly to the Upper Triassic, is not preserved, their aggregate thickness is at least several thousand feet. With the addition of similar strata that probably represent higher parts of the section in the West Humboldt Range and Eugene Mountains, the total original thickness of this assemblage in the vicinity of the Humboldt Range was probably much greater.

The thickest and most complete known section of these rocks is that described by Compton (1960) in the Santa Rosa Range about 60 miles north-northeast of the Humboldt Range. This section has a thickness of at least 20,000 feet. The lowest exposed part of this section is assigned to the Grass Valley Formation; successively higher units were assigned by him to the Winnemucca, O'Neill, Singas, Andorno, and Mullinix Formations. Except for minor amounts of calcareous and dolomitic rocks, all of this section is composed of metapelitic, silty, and sandy rocks that "had essentially one source and were deposited under similar conditions" (Compton, 1960, p. 1389). The general features recognized by Compton are equally descriptive of the equivalent strata, including the Grass Valley Formation, farther south: (1) pelitic rocks, commonly chloritic metapelites, predominate; (2) the coarser grained detrital constituents are the same throughout and con- sist of quartzose, somewhat albitic silt and sand, conspicuous amounts of micaceous material, and greater than normal amounts of relatively stable heavy minerals; (3) terrigenous clastic sediment, coarser than medium sand is generally absent; (4) first-cycle volcanic debris is not a significant constituent; and (5) crossbedded rather than graded sandstones predominate, suggesting sedimentary transport mainly by tractional bottom currents. In addition to these generalities, where carbonate units are sporadically intercalated in the section the units commonly bear evidence of shallowwater deposition such as the local abundance of oysterlike pelecypods or the presence of hermatypic corals, coraline algae, or stromatolites.

Regional analysis of specific parts of this thick assemblage is complicated by problems of correlation caused by the lateral and vertical repetition of similar rock types, the structural complexity and metamorphism in some outcrop areas, and the scarcity of agediagnostic fossils. The Grass Valley Formation, because it is at the base of this assemblage and is locally overlain by the distinctive carbonate rocks of the Dun Glen Formation, is the only terrigenous clastic part of this assemblage that can yet be recognized as a discrete natural unit in several adjacent mountain ranges.

Lateral change within the Grass Valley is pronounced among its principal exposures, which are restricted to either end of the Humboldt Range, the northern East Range, northern Stillwater Range, and the Tobin Range. The thickness of the formation and its composition in terms of the proportions of generalized rock types at these different places is compared in figure 14 by means of pie diagrams. For the more northerly and westerly exposures, where the detailed internal stratigraphy of the formation cannot be determined, these diagrams are only estimates. Nonetheless, they are meaningful for the purpose of gross comparison in view of the strong differences between these exposures and those farther southeast.

The easternmost exposures of the Grass Valley Formation are in the Tobin Range, where it is about 1,700 feet thick and consists mainly of light-colored clean calcareous sandstone. Limestone forms a minor proportion and is represented for the most part by one or more

Figure 13.-Sedimentary structures of a single slab of thinbedded impure sandstone from the Grass Valley Formation on the crest of the northern East Range about 1 mile southeast of Dun Glen Peak. Left-right orientation the same for all three views, which are one-half natural size. Current direction generally from left to right. $A$, Smooth bottom surface marked by prod casts and other impact-mark casts. $B$, Sawn surface of cross section, showing current crossbedding. $C$, Top surface bearing linguoid ripple marks. 

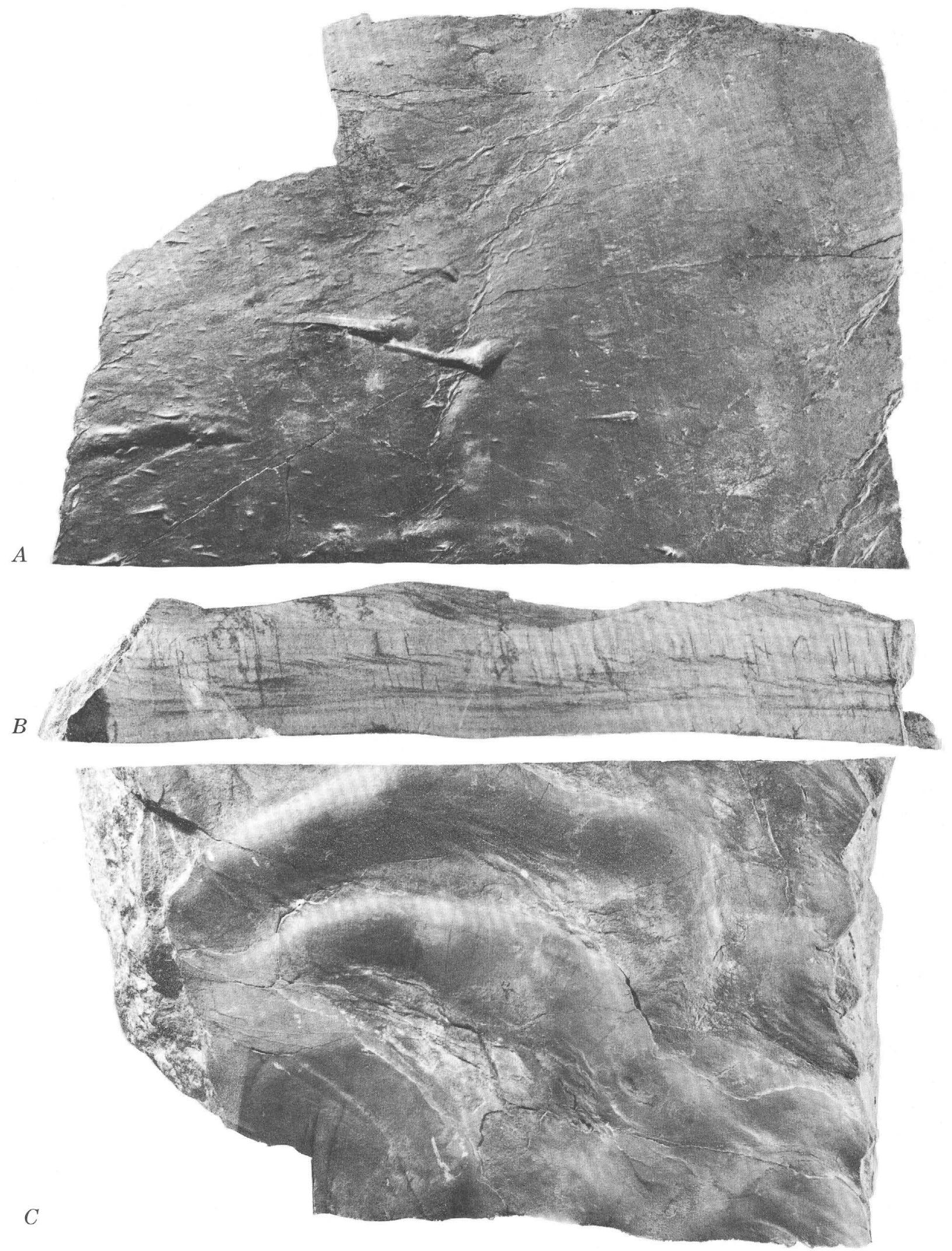


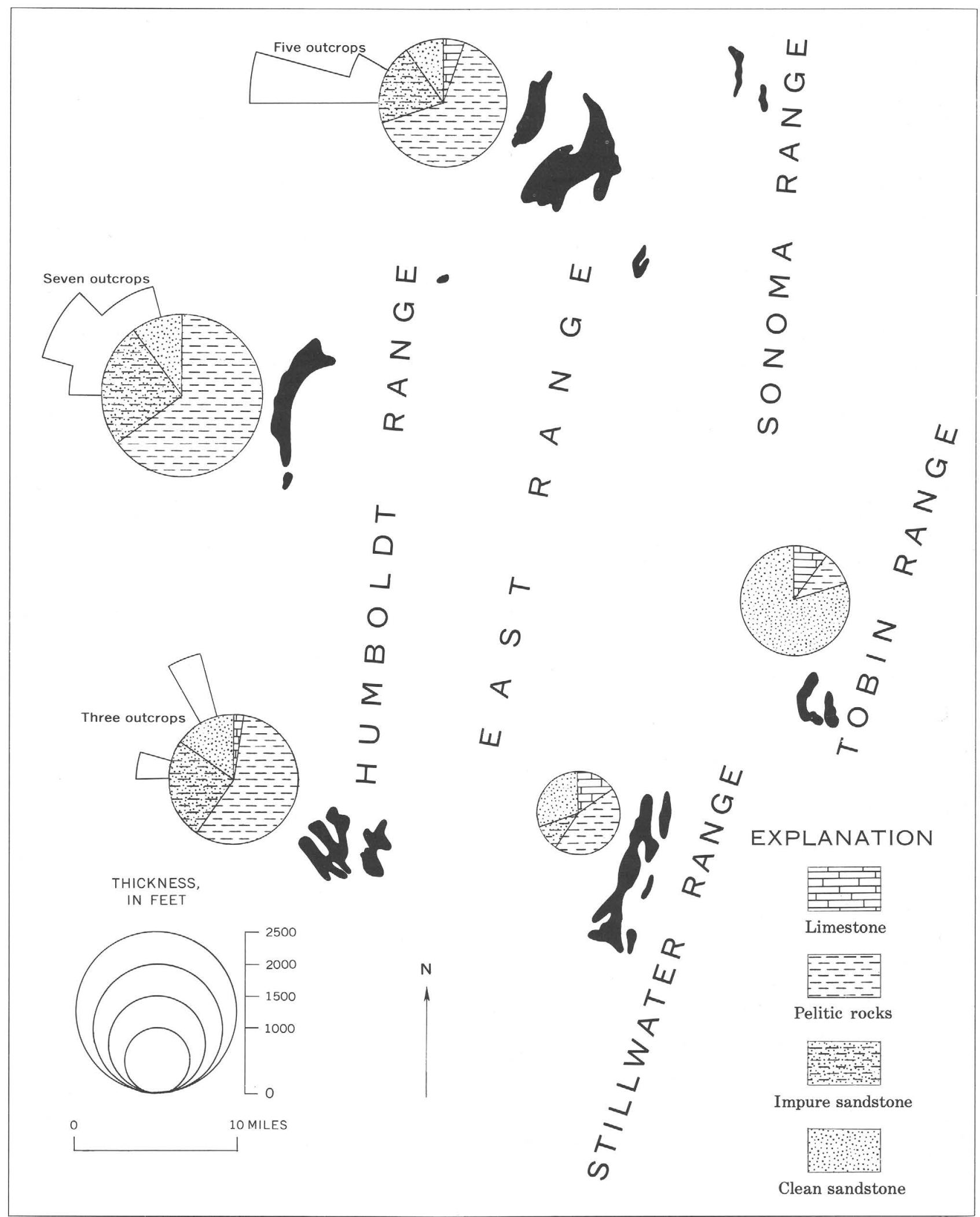


units of marine shelly detritus near the middle of the section. Interbedded units of argillaceous rocks are inconspicuous. The predominant sandstone is thick bedded and forms homogeneous units up to a few tens of feet thick that are distinguished from adjacent similar units by subtle differences in grain size, cementation, and bedding characteristics. Large-scale planar crossbedding is characteristic of most beds, and fossil auricarian logs are not uncommon near the top of the formation. The sedimentary environment suggested by these rocks is that of a beach or nearshore marine bar. Similar rocks that are approximately correlative, and evidently were deposited under much the same conditions, are included in the Osobb Formation, whose typical exposures are in the Augusta Mountains about 20 miles south of the Grass Valley exposures in the Tobin Range.

The exposures of the Grass Valley next west from the Tobin Range are in the northern Stillwater Range, where the formation is only about 1,300 feet thick. Approximately the upper half of the section here is similar to the Grass Valley of the Tobin Range in being composed predominantly of well-washed light-colored calcareous sandstone with subordinate interbedded units of limestone and argillaceous rocks. The lower part of the section, however, is noncalcareous pelitic rock with some siltstone and sandstone.

Compared with these exposures in the Tobin and Stillwater Ranges, the Grass Valley Formation in the Humboldt Range and the northern East Range farther west and north, differs greatly in thickness and composition. In these places, it is obviously thicker, although accurate measurement is not possible, and is largely composed of noncalcareous dark-colored pelitic rocks and impure siltstone and sandstone. Clean sandstones are poorly represented, and the minor proportion of limestone is restricted to the highest part of the section. Thus, although it is everywhere largely a fine-grained clastic formation sandwiched between the shallow-water marine carbonate rocks of the Natchez Pass and Dun Glen Formations, the Grass Valley undergoes a nearly complete change in character within a lateral distance of a few tens of miles.

Figure 14.--Thickness, composition, and paleocurrent directions of the Grass Valley Formation in the Humboldt Range and nearby ranges to the east. Solid black areas show the map distribution of the principal Grass Valley exposures, for each of which the thickness and composition of the formation is represented by the adjacent pie diagram. Current directions based on sedimentary structures-primarily linguoid ripple marks-of the thin-bedded impure sandstone units are plotted as rose diagrams on the outside of the pie diagrams. The length of each $15^{\circ}$ arc on the rose diagrams is proportional to the number of separate observations that fall within that arc.
Impure sandstones of the kind discussed in the description of the Grass Valley of the Humboldt Range are a subordinate, but distinctive, part of the pelitic sections in the Humboldt and East Ranges and are restricted to them. Prevalence of strongly directional linguoid ripple marks is characteristic of these impure sandstones, together with their consistent composition, very fine grain size, and occurrence in discontinuous sets of thin beds. Current directions were determined from these ripple marks wherever possible in the Humboldt Range, as well as in the vicinity of Dun Glen Canyon in the East Range, and are plotted in figure 14 in $15^{\circ}$ class intervals as rose diagrams around the peripheries of the pie diagrams for these localities. In general, the orientation of ripples on successive beds shows no perceptible difference, and each observation plotted represents the single current direction estimated visually for all the beds at one locality. In restoring these measurements to the horizontal-in some instances from an overturned position-folding was assumed to have been about horizontal axes. Unfortunately, localities where the bedding surfaces are exposed well enough that the sense of current direction of the linguoid ripples can be estimated directly are few. Nonetheless, the number of observations is sufficiently large, in view of the strong grouping of the observed current directions around a general west-northwest trend, to indicate that their distribution differs from a uniform distribution at a high level of significance. The magnitude of the resultant vector, based on the combined observations from the East Range and northern Humboldt Range, is about 93 percent. This northwesterly current direction is seaward and approximately perpendicular to the shoreline that would be inferred from the general distribution and character of Middle and Upper Triassic rocks in northwestern Nevada.

Also a part of the predominantly pelitic facies of the Grass Valley Formation, though less common than the impure sandstones, are the occasional laterally persistent units of well-washed light-colored sandstone. These clean sandstones tend to be massive but show some primary sedimentary structures-either planar internal lamination or crossbedding related to symmetrical oscillation ripple marks. Where measured in one part of the northern Humboldt Range, the crests and troughs of oscillation ripples, restored to the horizontal about a presumed horizontal fold axis, strike uniformly northeast, or at about right angles to the current direction indicated by the linguoid ripples of the impure sandstone beds in the same outcrop area.

Interpretation of the Grass Valley Formation as part of a near-shore deltaic complex is thought to best fit its combined characteristics and is in context with its role 
as one part of a much larger assemblage of similar finegrained terrigenous clastic sedimentary rocks. The relatively thick noncalcareous unfossiliferous pelitic sections of the Grass Valley in the Humboldt Range and northern East Range may represent the lobate part of a delta built westward into the marine basin out beyond the depositional site of correlative shoreline deposits of sandy and calcareous rocks like those that form the Grass Valley in the Tobin Range and the Osobb Formation still farther south and east.

The uniform current direction, lateral discontinuity, and other features of the impure sandstone units within the pelitic facies agree with interpretation of these sandstone units as channel deposits representative of the fluviatile distributary system on the delta surface. Associated units of clean sandstone may be in part beach and bar deposits formed during periods of sorting and winnowing by marine wave action and then incorporated in the muddy section of the delta by its further growth.

The partly calcareous uppermost several hundred feet of the Grass Valley Formation at the south end of the Humboldt Range is interpreted as having been deposited on the submarine slopes of the delta flank during the waning stages of Grass Valley delta building. Sedimentary features shown by the sandstone among these rocks include planar crossbedding, oscillation ripple marks, and, more rarely, flute casts on the soles of nongraded beds. Significantly, current-rippled impure sandstone beds, or the kind found elsewhere in the formation and interpreted as fluviatile channel deposits, are absent. Where measured in two places in the Pershing district, the orientation of flute casts indicates currents that were originally southward. Both flute casts and indications of southward-moving currents apparently are unique to this highest part of the Grass Valley section and may relate to marine depositional conditions.

The foregoing general interpretation of Grass Valley sedimentation implies deposition of the entire assemblage of fine-grained rocks, of which the Grass Valley Formation is a part, along a prograding shoreline. It also implies major river drainage into northwestern Nevada as a source for these sediments. No preexisting thick accumulation of fine-grained clastic sediment that could be readily cannibalized and redeposited was locally available. Nor could local uplift and rapid erosion of the Paleozoic section in western and central Nevada, which includes large proportions of resistent chert, quartzite, and volcanic rock, have yielded the necessary large volume of exclusively fine-grained terrigenous clastic sediment. A more reasonable speculation is that beginning in middle Late Triassic time the drainage from some large portion of the eastern Great Basin, the Colorado Plateau, and Rocky Mountain provinces, parts of which are known to have been alluviated areas of low relief at this time, found access through northern $\mathrm{Ne}$ vada to the sea. Deltaic deposits, like the pelitic facies of the Grass Valley Formation, may have formed at different times and places as the mouth of a river migrated north and south along the shoreline in northern central Nevada. Sediment thus delivered to the sea was further sorted and spread by marine depositional processes - the result being a thick extensive internally diverse assemblage of pelitic, silty, and sandy rocks.

\section{DUN GLEN FORMATION}

The Dun Glen Formation is mainly dark well-bedded massive limestone that forms prominent cliffs and cuestalike ridges in the Pershing district, at the southern tip of the Humboldt range in the Buffalo Mountain quadrangle. It is relatively thin-ranging from several tens to a few hundred feet in thickness-and contains fossils of middle Norian age. Nowhere farther north in the range are strata this high in the Mesozoic section preserved.

At its type locality in the northern East Range, as well as at its other exposures in the ranges immediately east of the Humboldt Range, the Dun Glen Formation is a homogeneous unit of massive dolomite or limestone that separates the Grass Valley and Winnemucca Formations. It is thus a lithologically distinctive entity within a thick section otherwise composed mainly of fine-grained terrigenous clastic rocks. The stratigraphic relations of the Dun Glen in the Humboldt Range are the same, but the overlying beds equivalent to the Winnemucca Formation are not assigned to a named formation.

Within the Pershing district, the thickness of the Dun Glen Formation is 100-150 feet at most places but ranges from as much as a few hundered feet to as little as 50 feet. In comparison, the formation is $500-600$ feet thick in the northern Stillwater Range, Tobin Range, and northern East Range and is 1,150 feet thick at its northeasternmost exposure in the Sonoma Range (Muller and others, 1951; Ferguson and others, 1951). Southwestward thinning is thus indicated by these widely scattered outcrops. The Dun Glen Formation apparently also thins northward from its type locality, as it is absent in the Santa Rosa Range according to Compton $(1960$, p. 1387). Because a persistent relatively pure carbonate unit like the Dun Glen is lacking, Compton placed the contact between his Grass Valley and Winnemucca Formations in the Santa Rosa Range at the lowed limit of the partly calcareous rocks assigned to his Winnemucca. This contact, however, would correspond lithologically to a level within the Grass Valley Formation in sections like those in the southern 
Humboldt Range and in the northern Stillwater Range in which the upper part of the Grass Valley is calcareous for an appreciable stratigraphic distance below the Dun Glen Formation. Where the Dun Glen is absent, there is, in fact, no means of recognizing formational boundaries that would precisely correspond genetically to those established in the typical succession of these formations near Winnemucca, and in such areas these formational names probably should not be used.

The Dun Glen Formation in the Pershing district crops out discontinuously along three generally parallel northwest-trending belts that delineate the major structures of the district. Outcrops of the northeastern belt, which extends from Packard Flat southeastward across South Relief Canyon for about $21 / 2$ miles where it is trunciated by the Relief fault, are in the overturned limb of a major anticline overturned to the northeast. The southwestern outcrop belt parallels the northwestern extension of Pershing Ridge- the ridge along which the Pershing mine is located-but toward the southeast is offset an echelon northeastward and repeated structurally. These Dun Glen exposures are in the overturned limb of a major anticline overturned to the southwest. The central belt of Dun Glen outcrops is areally the most extensive of the three. It includes the exposures that form Juniper Ridge-the ridge on which the Juniper mine is located - and the discontinuous Dun Glen outcrops farther southeast on the same trend. Small-scale contortions abound within the Dun Glye of Juniper Ridge, but, as a whole, the formation in this central belt is upright and on or near the axis of a major syncline on either side of which are major anticlines that are overturned away from it.

To use the Dun Glen Formation as an objective lithologic unit, the authors have assigned to it here only the thickest stratigraphically uninterrupted and laterally persistent predominantly carbonate unit along each of its outcrop belts; stratigraphically higher and lower carbonate beds locally included within the adjacent pelitic and sandy strata are excluded from it. Defined in this way, the thickness and composition of the Dun Glen varies markedly from one outcrop belt to another and even to some extent along the same belt. These variations have no apparent geographic trend and evidently result mainly from rapid intertonguing of the carbonate rocks assigned to the Dun Glen and the enclosing partly calcareous terrigenous clastic rocks.

\section{LITHOLOGIC DESCRIPTION}

Medium- to dark-gray massive limestone in well-defined medium to very thick beds characterizes the Dun Glen Formation, but dolomite, intraclastic limestone or dolomite breccia, sandy limestone, and calcareous sand- stone are locally well represented. Although bedding within the formation is commonly contorted and the carbonate rocks are much fractured and veined with calcite, recrystallization is generally not megascopically apparent.

Most of the limestone is superficially similar in aspect and is either entirely fine grained in appearance or fragmental with a fine-grained matrix. The matrix consists of very finely crystalline $(0.005-0.01 \mathrm{~mm})$ equigranular calcite that has been recrystallized from either a micrite or a calcilutite. Sparry calcite cement is unusual. Allochemical constituents vary widely in abundance, size, and kind. Most common is shelly organic detritus, intraclasts, or mixtures of the two. Other samples that megascopically appear homogeneous prove to be either pelletal or oolitic when viewed in thin section. A few scattered grains of detrital quartz, albite, and muscovite are usually present, and some of the limestone is sufficiently impure to weather brownish gray. Isolated rhombs and scattered patches of secondary dolomite are also commonly seen in thin section, and in places significant portions of the Dun Glen limestone have been altered to finely crystalline dolomite that tends to weather brownish gray or yellowish brown.

Intraclastic limestone or dolomite sedimentary breccia (the "limestone conglomerate" of Bailey and Phoenix, 1944, p. 162-163, 167-168) is a distinctive, though usually minor, part of the formation and intergrades with the finer grained carbonate rocks. It is thickest in the vicinity of the Juniper and Red Bird quicksilver mines, where it forms most of the upper part of the formation and is the host rock for these mercury deposits. Owing to structural complications, most of the Dun Glen cropping out at the Red Bird mine is that part characterized by carbonate breccia, and its thickness is duplicated by faulting. The dolomitic parts of the carbonate breccia have an irregular distribution and are evidently the result of local secondary alteration of limestone breccia. Characteristically, the breccias consist of sand- to pebble-size angular fragments that are rudely stratified by maximum grain size and are so closely packed as to be nearly devoid of matrix (fig. 15A). In thin section, the intraclast boundaries appear as pigmented irregular stylolitelike seams along which occur occasional sand-size grains of quartz. This peculiar texture suggests that the clasts of calcareous mud were sufficiently cohesive to be transported and mixed together as angular fragments by currents strong enough to winnow out any finer grained detritus and yet too plastic to maintain a porous rigid framework within which sparry calcite could be deposited. Intraclasts include : a variety of organic-detrital, pelletal, and oolitic dark-gray limestone; 
impure argillaceous limestone that weathers pale orange gray or brownish gray; some coarse shelly detritus; and a few clasts of calcareous siltstone and sandstone. Gray- and brown-weathering interclasts are about equally abundant and give the breccia a distinctive mottled appearance. Some laminated brown- and grayweathering sandy limestone is interbedded with the breccia, and some brecica, particularly that locally present at the base of the formation, consists of poorly sorted limestone intraclasts sparsely scattered in impure sandy limestone.

In general, the Dun Glen sections in the Pershing district that are composed mainly of dense gray bedded limestone are the thinnest. The northeastern outcrop belt, which crosses South Relief Canyon, is entirely bedded gray limestone and only about 50 feet thick, though it is paralleled in part by an equal thickness of similar limestone in the upper part of the stratigraphically underlying Grass Valley Formation. The Dun Glen outcrop belt that parallels Pershing Ridge is mainly bedded gray limestone also, and its thickness varies from about 150 feet to several tens of feet-apparently it thins northwestward by interfingering with calcareous sandstone. At the southeast end of the outcrop belt that follows the trend of Juniper Ridge, near the Hollywood mine, the formation is $100-150$ feet thick and consists of bedded gray limestone with some discontinuous interbeds of calcareous sandstone. Northwestward along this outcrop belt the thickness of strata included in the Dun Glen increases to at least a few hundred feet near the Juniper mine, mainly by the addition of sedimentary breccias to the upper part of the formation. Though these breccias intergrade with the limestone and are inseparable from them as a map unit, they might originally have been an interbedded succession of limestone and fine-grained terrigenous clastic rocks like that which immediately overlies nearby sections of Dun Glen limestone. By differential reaction to strong wave action or other currents, the limestone may have been concentrated as a coarse clastic deposit and the originally interbedded fine-grained terrigenous sediment been swept away. Thus, the anomalous thickness of the Dun Glen section here might have resulted from the local formation of limestone breccia in place or nearly so.

\section{FOSSILS AND AGE}

The limestones of the Dun Glen Formation and the calcareous beds in the immediately underlying strata locally contain an abundance of marine fossils. Few of these fossils are of much value for precise age determination, but many of them, such as hermatypic corals, coralline algae, and thick-shelled oysterlike pelecypods, are of considerably importance as indicators of extremely shallow marine depositional conditions. Fortunately, a few diagnostic middle Norian ammonites have also been found that provide a firm basis for dating these rocks in the Humboldt Range and, by lithologic correlation, for assigning an age to the equivalent part of the section in nearby ranges.

The most fossiliferous locality, originally discovered by Prof. S. W. Muller of Stanford University, is about half a mile south of the Juniper Mine (USGS Mesozoic loc. M96) and along strike, in the calcareous, argillaceous, and sandy strata just below the Dun Glen Formation and above a thick lense or tongue of massive organic-detrital limestone in the Grass Valley Formation. Included in the large and varied assemblage from this locality are the ammonites Indojuvavites cf. I. angulatus (Diener) and Arcestes; the nautiloids Clydonautilus cf. $C$. noricus Mojsisovics and Paranautilus: "Alectryonia," Lima, Cassianella, Minetrigonia?, Sep. tocardia? nuculid, mytilid, megalodontid, and other pelecypods; Plectoconcha aequiplicata (Gabb), Spondylospira?, and other brachiopods; indeterminate molds of large gastropods; echinoid and crinoid debris; colonial corals of several kinds; Heptastylis and other spongiomorphs; and Solenopora-like algae. Except for the cephalopods, for which this particular locality is unique, this same assemblage, commonly with the addition of the pelecypods Pinna and "Trichites" and blocks of auricarian wood, occurs either in or just below the Dun Glen Formation at a number of other places in the Pershing district and in the northern Stillwater Range and Tobin Range. Plectoconcha aequipticata (Gabb) was originally described from the northern Stillwater Range, presumably from these beds to which it is restricted and in which it is common.

Two other occurrences of ammonites in the Pershing district are in the partly calcareous upper Grass Valley Formation that forms the core of the faulted overturned anticline between Pershing and Juniper Ridges. Flattened impressions questionably identified as Indojuvavites cf. I. angulatus occur at USGS Mesozoic locality M1188 in impure limestone a few hundred feet below the Dun Glen Formation in the overturned limb of the anticline and at a stratigraphic level comparable to that of locality M96, where this species occurs in the up-

FIGURE 15.-Carbonate breccia and conglomerate from Upper Triassic rocks of the Pershing district in the southern Humboldt Range. Photographs only slightly reduced from natural size. A, Sawn surface of limestone sedimentary breccia from the upper part of the Dun Glen Formation on Juniper Ridge about a quarter of a mile northeast of the Juniper mine. $B$, Weathered surface of dolomite conglomerate from the lower part of the lower unit of post-Dun Glen strata on Pershing Ridgè near the Pershing mine. 

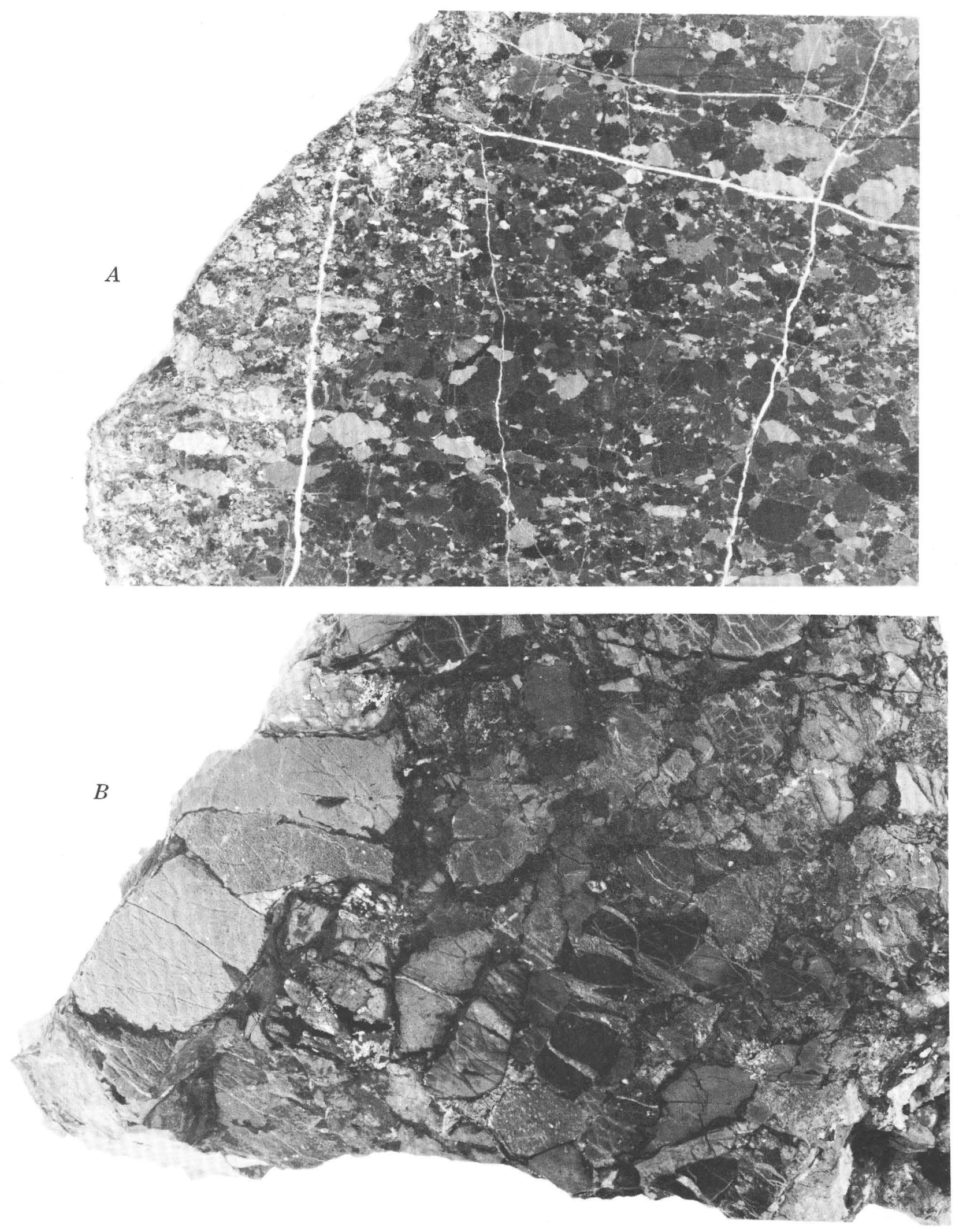
right, northeastern limb. At an apparently lower stratigraphic level closer to the anticlinal axis, at USGS Mesozoic locality M1191, are ammonite impressions with distinctive ornamentation like that of Pterotoceras caurinum McLearn.

A single specimen of Juvavites magnus McLearn was collected from USGS Mesozoic M664 within the Dun Glen Formation at the northwest end of Pershing Ridge; it was in association with large-sized megalodontid pelecypods. North of South Relief Canyon, at USGS Mesozoic locality M1187, a large specimen of Metacarnites was found, also within limestones of the Dun Glen Formation.

Though limited in variety, the ammonites from the Dun Glen and the immediately underlying part of the Grass Valley Formation can be dated within fairly close limits by comparison with the Upper Triassic faunal succession of the Pardonet Formation in the Peace River Foothills of northeastern British Columbia established by the late F. H. McLearn (1960). Juvavites magnus is the nominal index species for the zone, among those zones erected by Tozer (1965a) for McLearn's succession, that is regarded as the lowest faunal subdivision of the middle Norian in North America (Siberling and Tozer, 1968). In the Peace River Foothills, Pterotoceras caurinum also occurs in the J. magnus Zone. Metacarnites has been found in place in northeastern British Columbia only in the next higher Drepanites rutherfordi Zone, which represents the middle part of the middle Norian. Indojuvavites cf. I. angulatus was also recorded from the Pardonet Formation by McLearn (1960, p. 18, 92), but from an unknown stratigraphic level.

In summary, on the basis of fossil correlations, the Dun Glen Formation and the calcareous rocks that form the highest part of the underlying Grass Valley Formation in the Pershing district represent the lower part, and perhaps also the middle part, of the middle Norian substage.

\section{POST-DUN GLEN LOWER MESOZOIC STRATA IN THE PERSHING DISTRICT}

The lower Mesozoic strata that succeed the Dun Glen Formation in the Pershing district, at the southern tip of the Humboldt Range, include a variety of partly calcareous fine-grained terrigenous clastic sedimentary rocks and some interbedded carbonate rocks. Most of these are Late Triassic in age, but some are Early Jurassic. These rocks are largely confined to the low ridges and hills in the southern and southwestern parts of the Pershing district and to the adjacent isolated outcrops that protrude from beneath the veneer of lacustrine and alluvial deposits along the margins of Antelope Valley and the Carson Sink.
Except for the beds immediately overlying the Dun Glen Formation, the limited extent and discontinuity of exposures of these structurally complicated rocks preclude determination of their stratigraphic succession in any detail. However, on the basis of lithologic differences and paleontologic evidence, the younger of these rocks can generally be separated from the older; hence, their various outcrops are apportioned on the geologic map between a "lower unit" and an "upper unit," although the stratigraphic relation between these two informal units is uncertain. In sections 16 and 17, T. 26 N., R. 34 E., southwest of Pershing Ridge, isolated exposures of the two units parallel one another concordantly for a strike distance of about 1 mile; the two units appear to be in normal depositional sequence. Nevertheless, owing to their limited areal extent and incomplete exposures, little useful purpose would be served by establishing formally named lithologic units here. They are lithologically similar, partly correlative, and probably genetically related to the Winnemucca Formation (Muller and others, 1951) and the Raspberry Formation (Ferguson and others, 1951) which were named for exposures in the Sonoma Range and the northern East Range respectively. These formations, however, cannot be readily recognized away from their typical outcrops because, as defined, they are neither unique in lithologic composition nor bracketed by distinctive stratigraphic boundaries.

\section{LOWER UNIT}

The lower unit of post-Dun Glen strata in the Pershing district includes the beds that depositionally overlie the Dun Glen Formation. In most places as much of the section as is exposed forms a fairly homogeneous unit; here, younger beds, which are distinctive elsewhere, have been eroded or faulted away.

Some of the lower unit overlies the Dun Glen Formation along all three of its outcrop belts in the Pershing district. More than 1,000 feet of the lower unit is exposed in the overturned section between the northeastern belt of Dun Glen and the Relief fault. These rocks are essentially like the highest part of the Grass Valley Formation, from which they are separated only by the relatively thin Dun Glen Formation. They consist of highly fractured partly silty argillite that weathers yellowish brown, light brown, or pale red, and subordinate interbedded clean light-colored sandstone. From a distance, the weathered slopes are grayish orange with streaks of light gray produced by the sandstone units that are unevenly distributed through the section. Sandstone forms only several percent of the total thickness and rarely forms units more than a few 
feet thick. Much of it is crossbedded, and in places wellformed oscillation ripple marks are preserved.

Along their central belt of exposures, the contorted and intricately faulted Dun Glen carbonate rocks are locally overlain by as much as a few hundred feet of red-weathering argillaceous rocks. The contact between these rocks of the lower unit and the Dun Glen was explored by the principal workings of the Juniper and Red Bird (Antelope Springs) mines (Bailey and Phoenix, 1944, p. 162-167).

The most extensive exposures of the lower unit of post-Dun Glen rocks border the southwestern belt of Dun Glen outcrops on their southwest side. All of the beds in these exposures are overturned, and they are separated by a concealed fault, trending northward through the east edge of secs. 10 and 15, T. 26 N., R. 34 $\mathrm{W}$., from isolated ridges of the same strata in an upright position at the southeast end of the synclinal belt that follows Juniper Ridge. The lower unit of post-Dun Glen strata in the southern and southeastern Pershing district is formed mainly of fine-grained terrigenous clastic rocks that weather to light, moderately saturated, yellow-red hues; in contrast with the sections in the northwestern part of the district, it includes a conspicuous ridge-forming unit of dolomite conglomerate in its lower part. This distinctive unit caps Pershing Ridge; and several shorter, subsidiary ridges that parallel the southeast end of Pershing Ridge owe their existence to structural repetition of the dolomite conglomerate. A few hundred feet of red-weathering partly silty argillaceous rocks separates the northwest-dipping strike ridges of dolomite conglomerate from those of the stratigraphically lower, massive carbonate rocks of the Dun Glen Formation, so that where not complicated by strike faulting, these two carbonate units of differing character form a couplet with similar topographic expression.

Possibly the dolomite conglomerate on Pershing Ridge correlates with the sedimentary breccia of carbonate rocks that forms the upper part of the Dun Glen Formation on Juniper Ridge and accounts for the anomalously great thickness of the formation there, but discontinuity of exposures precludes tracing the two together. It is noteworthy, however, that the principal quicksilver deposits in the district are restricted to these two rock types, which are at least approximate lateral equivalents.

The dolomite conglomerate of Pershing Ridge ranges in thickness from 10 to about 100 feet, the more southeasterly exposures being the thickest. It is massive and homogeneous except for crude stratification resulting from variation in the size of the clasts, which are mostly less than 2 inches in diameter but range up to 16 inches in greatest dimension. Most of the clasts are subangular to subrounded dolomite that displays a variety of different textures and ranges in unweathered color from dark gray to grayish orange. Other clasts include lightbrown dolomitic siltstone and, more rarely, chert. Sorting is poor, and the conglomerate clasts are closely packed; grayish-orange dolomitic sandstone fllls the interstices between them. A representative slab is shown in figure $15 B$. Throughout the extent of its outcrops, the carbonate components of this unit are wholly dolomitic. As the carbonate rocks of the Dun Glen Formation a short distance stratigraphically below the dolomite conglomerate are calcareous and the terrigenous clastic rocks stratigraphically just above it are partly calcareous and include some interbedded limestone, dolomitization of the conglomerate was remarkably selective and hence perhaps diagenetic. This stratigraphic selectivity of dolomitization might also relate to a relatively high permeability of the conglomerate with respect to secondary mineralizing fluids-a factor that may be of significance in explaining the localization in this unit of the quicksilver deposits along Pershing Ridge. Other factors, however, such as the fracturing of the dolomite conglomerate unit due to its difference in competency from the enclosing pelitic rocks, have no doubt also influenced mercury mineralization.

Near the Pershing mine, where exposures are better than in most places, the dolomite conglomerate is stratigraphically overlain by up to several feet of well-sorted grayish-orange limy sandstone that is in turn overlain by several tens of feet of poorly bedded brown-weathering dark-gray sandstone. The grayish-orange ("buffcolored") unit, where present at the stratigraphic base of this sandstone sequence, formed a useful marker bed in the underground mercury-mine workings and is reported to be interbedded with the stratigraphically upper part of the dolomite conglomerate farther east along Pershing Ridge (Bailey and Phoenix, 1944, p. 166). Stratigraphically higher parts of this overturned section, above the dark standstone, are mainly flaky, finely fractured pelitic rocks ("shale"); a few feet of impure limestone occurs about 150 feet stratigraphically above the dolomite conglomerate.

About 2,000 feet southwest of Pershing Ridge, the dolomite conglomerate unit is repeated by a steeply dipping, apparently normal fault, and it is intermittently exposed as a vertically dipping rib that strikes through the SE $1 / 4$ sec. 8 and the NW1/4 sec. 16, T. 26 N., R. 34 E. Between these outcrops of the dolomite conglomerate and the parallel belt of Monotis-bearing calcareous strata assigned to the upper unit of post-Dun Glen rocks farther southwest, the poorly exposed section of the lower unit is monotonously the same and consists of 
orange- and light-brown-weathering partly silty argillaceous rocks with minor amounts of intercalated brown sandstone. These beds are either vertical or steeply overturned to the southwest, and, if unfaulted, this section of the lower unit above the dolomite conglomerate unit is about 2,000 feet thick.

For the most part, fossils are absent in the lower unit of post-Dun Glen strata. At an isolated exposure several hundred feet south of the southeastern tip of Pershing Ridge (USGS Mesozoic loc. M663), however, a large ammonite fauna was obtained from a few closely associated loose blocks that were evidently derived from a single highly fossiliferous bed. Included in this fauna are:

Himavatites columbianus McLearn

"Dittmarites" aff. "D." Tilli (Guembel)

Distichites sp. [immature specimens only]

"Sandlingites? sp." of McLearn (1960)

Pseudosirenites pardoneti (McLearn)

Helictites decorus McLearn

Helictites ef. H. subgeniculatus Mojsisovics

"Parajuvavites" sp. [similar to "Parajuvavites sp." of McLearn (1960)]

?Episculites cf. E. terres (McLearn)

Placites sp.

Arcestes sp.

All these ammonites, except "Dittmarites" aff. "D." lilli, are either conspecific with or closely related to those described by McLearn (1960) from the beds in the Peace River Foothills of northeastern British Columbia. The ammonites are typical of the Himavatites columbianus Zone of Tozer (1965a), which is regarded as late middle Norian in age (Silberling and Tozer, 1968).

If this isolated fossil locality is projected into the overturned section of the lower unit of post-Dun Glen rocks on the southwest side of Pershing Ridge, it falls at a horizon within a few hundred feet stratigraphically above the dolomite conglomerate unit. As a conclealed fault of significant displacement could easily exist between this locality and the continuous exposures of the lower unit on Pershing Ridge, the stratigraphic position of this critical ammonite fauna would be only speculative were it not for a single well-preserved specimen assignable to Distichites cf. D. mesacanthus Mojsisovics found by Prof. S. W. Muller on the southwest slope of Pershing Ridge just west of the Pershing mine furnace (about 1,400 ft north of the SE. cor. sec. 8, T. 26 N., R. 34 E.) at a stratigraphic level about 300 feet stratigraphically above the dolomite conglomerate unit. As far as is known, Distichites is restricted to the Himavatites columbianus Zone in North America, and species similar to that represented by Professor Muller's spec- imen were described by McLearn (1960) from the $H$. columbianus Zone of Northeastern British Columbia.

The lower part of the lower unit of post-Dun Glen rocks can thus be independently dated on the basis of faunal evidence as late middle Norian. As these rocks are in stratigraphic succession with the Dun Glen Formation, which contains fossils of early middle Norian age, the faunal evidence confirms the structural interpretation whereby the Grass Valley, Dun Glen, and post-Dun Glen rocks in the vicinity of Pershing Ridge are all regarded as overturned. The upper age limit of the lower unit of post-Dun Glen strata is restricted by the occurrence of upper Norian fossils in the overlying strata assigned to the upper unit of post-Dun Glen rocks.

At least the lower part of the lower unit of post-Dun Glen strata in the Humboldt Range is equivalent to the Winnemucca Formation in the nearby ranges to the east, where the Winnemucca overlies the Dun Glen Formation but lacks a stratigraphically defined upper limit. No age-diagnostic fossils have been found in the Winnemucca Formation and hence the best evidence for its age is the occurrence of the upper middle Norian Himavatites columbianus Zone at a stratigraphically analogous position in the Pershing district section. The Karnian age suggested for fossils from the so-called Winnemucca Formation of the Santa Rosa Range by Compton (1960, p. 1387) is almost certainly wrong, provided that the lithologic correlation of these beds with the type Winnemucca Formation of the Sonoma Range is correct.

\section{UPPER UNIT}

Exposures assigned to the upper unit of post-Dun Glen strata are restricted to an area of about 2 square miles in the southernmost part of the Pershing district, where they occur mostly in scattered structurally discordant outcrops separated from one another by Quaternary deposits. Lithologically they are heterogeneous and include a variety of interbedded sedimentary rocks-calcareous siltstone and sandstone, impure limestone, siltstone, and pelitic rocks-no one of which dominates more than a few hundred feet of section. Compared with the lower unit of post-Dun Glen strata, the upper unit includes proportionally more sandy and calcareous rocks. Pelitic rocks appear to be subordinate in the upper unit, though this appearance is probably due in part to their nonresistant, poorly outcropping nature.

The thickest apparently uninterrupted partial section of the upper unit is in north-central sec. 17, T. 26 N., R. 34 E. Here the upper unit appears to rest conformably on the lower unit of post-Dun Glen strata; more than 1,000 feet of the upper unit is exposed and 
dips moderately to steeply southwest in an upright position. In ascending order, the following units are represented :

1. Brown- and yellow-brown-weathering sandstone, partly calcareous, with lenticular interbeds of dense black, orange-brown-weathering, silty limestone ; estimated thickness a few hundred feet; Monotis subcircularis Gabb locally abundant, as at USGS Mesozoic locality M1667.

2. Finely fractured argillite, olive-gray or brown, with interbeds of laminated siltstone; about 300 feet thick.

3. Calcareous very thin bedded siltstone, with subordinate silty limestone; about 200 feet thick.

4. Massive gray partly dolomitic limestone; partly conglomeratic; stromatolitic at top; about 100 feet thick.

5. Calcareous siltstone; very thin bedded; weathers pale red, light brown, or medium gray; exposed thickness a few hundred feet.

Fossils are fairly common in the upper unit and are widely enough distributed to be useful in identifying isolated exposures as belonging to this map unit. As the upper Norian pelecypod Monotis subcircularis Gabb is especially characteristic, the beds herein assigned to the upper unit of post-Dun Glen strata were informally designated the "beds containing Monotis" on the preliminary geologic map of the Buffalo Mountain quadrangle (Wallace and others, 1959). In addition to its occurrence at USGS Mesozoic locality M667, and along strike, $M$. subcircularis is found at and near USGS Mesozoic locality M658 and at other places not plotted on the geologic map. Isolated fossiliferous exposures in the $\mathrm{SW} 1 / 4$ sec. 17 , the $\mathrm{NW} 1 / 4$ sec. 20 , and the $\mathrm{N} 1 / 2$ sec. 21 , T. 26 N., R. 34 E., evidently represent the lower parts of the upper unit of post-Dun Glen strata repeated by concealed faults. Some of these exposures consist of only a few square feet of outcrop surrounded by lacustrine deposits of Pleistocene Lake Lahontan and encrusted with calcareous tufa. Locally in these isolated exposures, such as at USGS Mesozoic locality M660, Monotis subcircularis is found associated with the ammonites Placites, Rhabdoceras, and Sandlingites? From this and nearby isolated localities, Prof. S. W. Muller, of Stanford University, collected, in addition to these forms, the ammonites Pinacoceras cf. P. rex Mojsisovics, Sagenites cf. S. giebeli (Hauer), Metasibirites, and Arcestes. All these faunas are indicative of the upper Norian Rhabdoceras suessi zone of Silberling and Tozer (1968) and Tozer (1967).

Isolated outcrops of limestone northwest along strike from the stromatolitic limestone unit in the section itemized above locally contain (as at USGS Mesozoic loc. M670), an abundance of pelecypods closely simi- lar to Pecten tyaughtonae McLearn, which in southwestern British Columbia is part of the upper Norian pelecypod fauna of the Tyaughton Group (McLearn, 1960, p. 37).

In addition to these occurrences of upper Norian fossils in the upper unit, Lower Jurassic fossils occur about 1 mile south of the southeast end of Pershing Ridge at two closely spaced but isolated localities, USGS Mesozoic localities M662 and M669. From the former, Pseudotropites cf. P. ultratriassicus (Canavari) and other ammonites whose closest resemblance is to Franziceras-like psiloceratinids were collected along with stylophyllid solitary corals, gastropods, and a variety of indeterminate pelecypods from silty brownish-gray partly conglomeratic limestone. These fossils occur as broken coarse-clastic debris and are associated with granules and pebbles of siltstone. The ammonites indicate an Early Jurassic age no younger than early Sinemurian.

From the nearby locality $\mathbf{M} 669$, which is less than 200 feet northeast from locality M662, Harpoceras-like hildoceratid ammonites of Toarcian age were collected from thin-bedded impure limestone and calcareous siltstone in another small isolated exposure. The explanation for the geographic proximity of these two faunas of widely different age within the Lower Jurassic is not certainly known, and their relations are obscured by the lack of exposure between the fossil localities. As the beds in which they occur dip northeast, and they are thus apparently in their proper stratigraphic sequence, a disconformity could separate the two. Alternatively, the older fauna could have been reworked, or, more likely, a concealed fault may intervene between them. A concealed fault is probably also required northeast of loclaity $\mathrm{M} 669$ between it and the nearby ridge of northeast-dipping massive limestone that resembles the stromotolitic unit in the more complete section about 2 miles farther west.

Impure conglomeratic limestone resembling that at locality M662 and perhaps also of Early Jurassic age, forms another small isolated outcrop about 1 mile southwest of locality M662.

\section{REFERENCES}

Arkell, W. J., Kummel, Bernhard, and Wright, C. W., 1957, Mesozoic Ammonoidea, in Mollusea 4, Pt. L of Moore, R. C., ed., Treatise on invertebrate paleontology : New York, Geol. Soc. America and Kansas Univ. Press [Lawrence], p. L80L471.

Bailey, E. H., and Phoenix, D. A., 1944, Quicksilver deposits in Nevada: Nevada Univ. Bull., v. 38, no. 5, Geol. and Mining Ser. 41, $206 \mathrm{p}$.

Cameron, E. N., 1939, Geology and mineralization of the northeastern Humboldt Range, Nevada : Geol. Soc. America Bull., v. 50, no. 4, p. $563-633$. 
Compton, R. R., 1960 Contact metamorphism in Santa Rosa Range, Nevada: Geol. Soc. America Bull., v. 71, no. 9, p. 1383-1416.

Davidson, Pirie, 1919, A cestraciont spine from the middle Triassic of Nevada: California Univ., Dept. Geology Bull., v. 11 , no. 4, pp. $433-435$.

Dzułynski, Stanisław, and Sanders, J. E., 1962, Current marks on firm mud bottoms: Connecticut Acad. Arts and Sci. Trans., v. 42, p. 57-96, 22 pls.

Ferguson, H. G., Muller, S.W., and Roberts, R. J., 1951, Geology of the Winnemucca quadrangle, Nevada: U.S. Geol. Survey Geol. Quad. Map GQ-11.

Folk, R. L., 1959, Practical petrographic classification of limestones: Am. Assoc. Petroleum Geologists Bull., r. 43, no 1, p. 1-38.

1962, Spectral subdivision of limestone types, in Ham, W. E., ed., Classification of carbonate rocks-a symposium: Am. Assoc. Petroleum Geologists Mem. 1, p. 62-84.

Gabb, W. M., 1864, Description of the Triassic fossils of California and the adjacent territories: California Geol. Survey, Paleontology, v. 1, p. 17-35, pls. 3, 4 .

Givens, C. R., and Susuki, Takeo, 1963, Late Triassic fauna from interlava sediments of east-central Vanconver Island [abs.] : Geol. Soc. America, Cordilleran Sec.-Seismol. Soc. AmericaPaleont. Soc., Pacific Coast Sec., 59th Ann. Mtg., Berkeley, Calif., 1963, Program, p. 35.

Goddard, E. N., chm., and others, 1948, Rock-color chart: Washington, Natl. Research Council (repub. by Geol. Soc. America, 1963), $6 \mathrm{p}$.

Hague, Arnold, and Emmons, S. F., 1877, Descriptive geology : U.S. Geol. Explor. 40th Parallel (King), v. 2, 890 p.

Hyatt, Alpheus, and Smith, J. P., 1905, The Triassic cephalopod genera of America: U.S. Geol. Survey Prof. Paper 40, 394 p., 85 pls.

Ingram, R. L., 1954, Terminology for the thickness of stratification and parting units in sedimentary rocks: Geol. Soc. America Bull., v. 65, no. 9 p. 937-938.

Keith, M. L., and Weber, J. N., 1964, Carbon and oxygen isotopic composition of selected limestones and fossils: Geochim. et Cosmochim. Acta, v. 28, no. 11, p. 1787-1816.

King, Clarence, 1878, Systematic geology: U.S. Geol. Explor. 40th Parallel (King), v. 1, 803 p.

King, P. B., 1942, Permian of west Texas and southeastern New Mexico, Pt. 2 of DeFord, R. K., and Lloyd, E. R., ed., West Texas-New Mexico symposium: Am. Assoe. Petroleum Geologists Bull., v. 26, no. 4, p. 535-763. 1948, Geology of the southern Guadalupe Mountains, Texas: U.S. Geol. Survey Prof. Paper 215, 183 p.

-__ 1962, Leonard and Wolfcamp Series of Sierra Diablo region, Texas, in Leonardian facies of the Sierra Diablo region, West Texas, Guidebook, 1962 Field Trip: Soc. Econ. Paleontologists and Mineralologists Permian Basin Sec. Pub. 62-7, p. 42-65.

Knopf, Adoph, 1924, Geology and ore deposits of the Rochester district, Nevada: U.S. Geol. Survey Bull. 762, $7 \mathrm{~S}$ p.

Kummel, Bernhard, Jr., 1954, Triassic stratigraphy of southeastern Idaho and adjacent areas [Wyoming-Montana]: U.S. Geol. Survey Prof. Paper 254-H, p. 165-194.

McLearn, F. H., 1960, Ammonoid faunas of the Upper Triassic Pardonet formation, Peace River Foothills, British Columbia; Canada Geol. Surrey Mem. 311, 118 p. 21 pls.

Meek, F. B., 1877, Paleontology : U.S. Geol. Explor. 40th Parallel (King), v. 4, p. 1-197.
Merriam, J. C., 1908, Triassic Ichthyosauria, with special reference to American forms: California Univ. Mem. 1, $196 \mathrm{p}$.

Mosher, L. C., and Clark, D. L., 1965, Middle Triassic conodonts from the Prida Formation of northwestern Nevada: Jour. Paleontology, v. 39, no. 4, p. 551-565.

Muller, S. W., Ferguson, H. G., and Roberts, R. J. 1951, Geology of the Mount Tobin quadrangle, Nevada : U.S. Geol. Survey Geol. Quad. Map GQ-7.

Newell, N. D., Rigby, J. K., Fischer, A. G., Whiteman, A. J., Hickox, J. E., and Bradley, J. S., 1953, The Permian reef complex of the Guadalupe Mountains region, Texas and New Mexico; a study in paleoecology: San Francisco, Calif., W. H. Freeman and Co., 236 p.

Ransome, F. L., 1909, Notes on some mining districts in Humboldt County, Nevada: U.S. Geol. Survey Bull. 414, 75 p.

Silberling, N. J., 1961, Upper Triassic marine mollusks from the Natchez Pass formation in northwestern Nevada: Jour. Paleontology, v. 35, no. 3, 535-542, pl. 74 .

_ 1962, Stratigraphic distribution of Middle Traissic ammonites at Fossil Hill, Humboldt Range, Nevada: Jour. Paleontology, v. 36, no. 1, p. 153-160.

Silberling, N. J., and Roberts, R. J., 1962, Pre-Tertiary stratigraphy and structure of northwestern Nevada: Geol. Soc. America Spec. Paper 72, 58 p.

Silberling, N. J., and Tozer, E. T., 1968, Biostratigraphic classification of the marine Triassic in North America: Geol. Soc. America Spec. Paper 110, 63 p.

Silberling, N. J., and Wallace, R. E., 1967, Geology of the Imlay quadrangle, Pershing County. Nevada: U.S. Geol. Survey Geol. Quad. Map GQ-666.

Smith, J. P., 1914, The Middle Triassic marine invertebrate faunas of North America: U.S. Geol. Survey Prof. Paper 83,254 p., 99 pls.

Spath, L. F., 1934, The Ammonoidea of the Trias., Pt. 4 of Catalogue of the fossil Cephalopoda in the British Museum (Natural History) : London, Adlard and Son, Ltd., $521 \mathrm{p.}$

Tozer, E. T., 1965a, Upper Triassic ammonoid zones of the Peace River Foothills, British Columbia, and their bearing on the classification of the Norian Stage: Canadian Jour. Earth Sci., v. 2, no. 3, p. 216-226.

1965b, Lower Triassic stages and ammonoid zones of Arctic Canada: Canada Geol. Survey Paper 65-12, 14 p. 1967, Standard for Triassic time: Canada Geol. Survey Bull. 156, 103 p., 10 pls.

Wallace, R. E., Silberling, N. J., Irwin, W. P., and Tatlock, D. B., 1959, Preliminary geologic map of the Buffalo Mountain quadrangle, Nevada: I.S. Geol. Survey Mineral Inv. Field Studies Map MF-220.

Wallace, R. E., Tatlock, D. B., Silberling, N. J., and Irwin, W. P., 1960, Preliminary geologic map of the Unionville quadrangle, Nevada: U.S. Geol. Survey Mineral Inv. Field Studies Map MF-245.

Wemple, E. M., 1906, New cestraciont teeth from the west American Triassic: California Univ., Dept. Geology Bull., v. 5, p. $71-73$.

Wentworth, C. K., 1922, A scale of grade and class terms for clastic sediments: Jour. Geology, v. 30, no. 5, p. 377-392.

Wheeler, H. E., 1939, Helicoprion in the Anthracolithic (late Paleozoic) of Nevada and California, and its stratigraphic significance: Jour. Paleontology, v. 13, no. 1, p. 103-11t.

Winterer, E. L., and Murphy, M. A., 1960, Silurian reef complex and associated facies, central Nevada: Jour. Geology, v. 68 , no. 2 , p. $117-139$. 


\section{INDEX}

[Italic page numbers indicate major references]

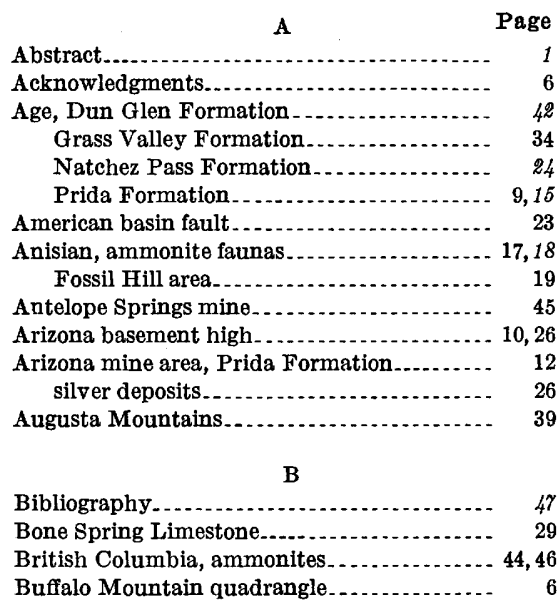

c

Carbonate unit, lower member, Prida Formation....................... 10 Chemical analyses, Natchez Pass Formation 22,

Chert, Prida Formation, upper member...... 14

\section{D}

Depositional environment, Dun Glen Formation.

Grass Valley Formation.

Natchez Pass Formation............... 28

Prida Formation. ................ 9, 13, 28

De Soto mine............................. 26

Dolomite conglomerate, Pershing Ridge..... 45

Dun Glen Formation, description.......... $\quad 40$

Dzułynski, Stanisław, acknowledgments ..... 6

E

East Range.

$8,25,28,30$

Eugene Range.

F

Facies relation, Prida and Natchez Pass Formations and Natchez Pass

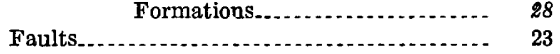

Fitting, Nev . . . . . . .

Fossil Hill................................ 17, 19, 20

Fossil Hill area, Anisian faunal units. ..... 19 Fossils:

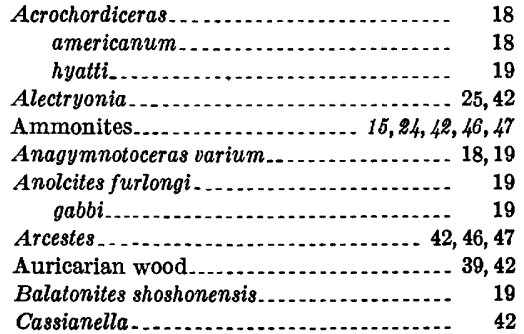

Clydonautilus noricuss-

corals $\ldots \ldots \ldots \ldots \ldots . . . \ldots 2,47$

Cuccoceras bonaevistae................... 19

Czekanowskites hayesi

Daonella............................... 13,18, 19

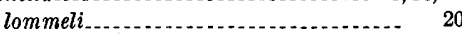
taramellii_.......................... 20

Distichites mesacanthus.

Dittmarites lilli.......

Drepanites rutherfordi.

Dun Glen Formation.

Eophyllites.

Episculites terres

Franziceras.

Frechites.

(1)

Gymnites perplanus................................

Gymnotoceras blakei.................... 19

dunni............................. 13, 19

meeki.......................... 13,19,20, 25

nevadanus.......................... 19

rotelliformis ...................... 19, 20, 25

washburnei........................ 19

Halobia ornatissima.

superba.

Harpoceras.

Helictites decorus

$$
\text { subgeniculatus. }
$$

Heptastylis..

Himavatites columbianus ...................

Hungarites

yatesi

ichthyosaurs...................................

Indojuvavites angulatus

Isculites. .

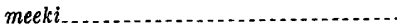

Juvavites magnus .

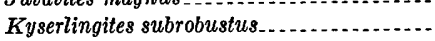

Lenotropites caurus.

Longobardites caurus.

Longobardites

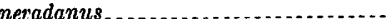

Lower Jurassic.

Metacarnites.

Minetrigonia

Monotis.

subcircularis.

Natchez Pass Formation

Neopopanoceras haugi................ 15, 17,18

gabbi

hyatti..............................

humboldtensis.

Paraceratites burckhardti................. clarkei.....................................

cricki.-

Parajunanites.

Paranautilus.

Paratropites sulcatus

Pecten tyaughtonae

Pinacoceras rex occidentalis........................... 19,20,25

Nevadites furlongi.
Fossils-Continued Page Pinna ................................ 42

Placites............................... 46, 47

Placunopsis........................ 25

Plectoconcha aequiplicata................. 42

Posidonia............................. 18

post-Dun Glen strata.................... 46

Prida Formation ......................... 14, 15

Proarcestes

Prohungarites........................... 15

Protrachyceras subasperum ............... 19, 20

Pseudodanubites halli..................... 19

Pseudosirenites pardoneti.................. 46

Pseudotropitis ultratriassicus............. 47

Pterotoceras caurinum ..................... 44

Ptychites................................ 19

radiolaria................................. 14

Rhabdoceras suessi...................... 47

Rhynchopterus obesus................... 18

Sageceras............................... 20

Sagenites giebeli............................... 47

Sandlingites............................... 46, 47

Septocardia............................. 25,42

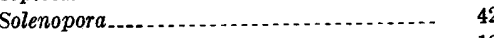

Sphaera whitneyi........................ 18

Spirigera stoliczkai...................... 18

Spirogmoceras shastense................. 25

Spondylospira......................... 42

sponge spisules......................... 14

Subcolumbites............................... 15, 17

Thecosmilia............................ 22

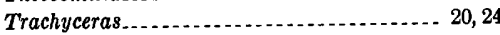

Trichites................................. 42

Tropites dilleri......................... 25

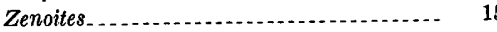

Fourth of July Flat

\section{G}

Grass Valley delta

Grass Valley Formation............. 7,20

description .............................. 31

lithologic description. ................. 31

paleogeographic interpretation........... 36

\section{H}

Hillside mine

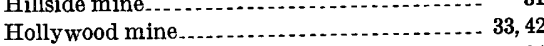

Humboldt City thrust .................... 15, 20, 24

Humboldt Range, geographic setting ......... 8$$
\text { I }
$$

Imlay quadrangle ........................... 6

Isotopic composition, middle member, Prida Formation.

$$
\mathrm{J}
$$

Juniper mine. 41,45

Juniper Ridge

$\mathbf{K}$

Koipato Group............................. 7

Koipato rhyolite porphyry

L

Limerick Greenstone.

.....




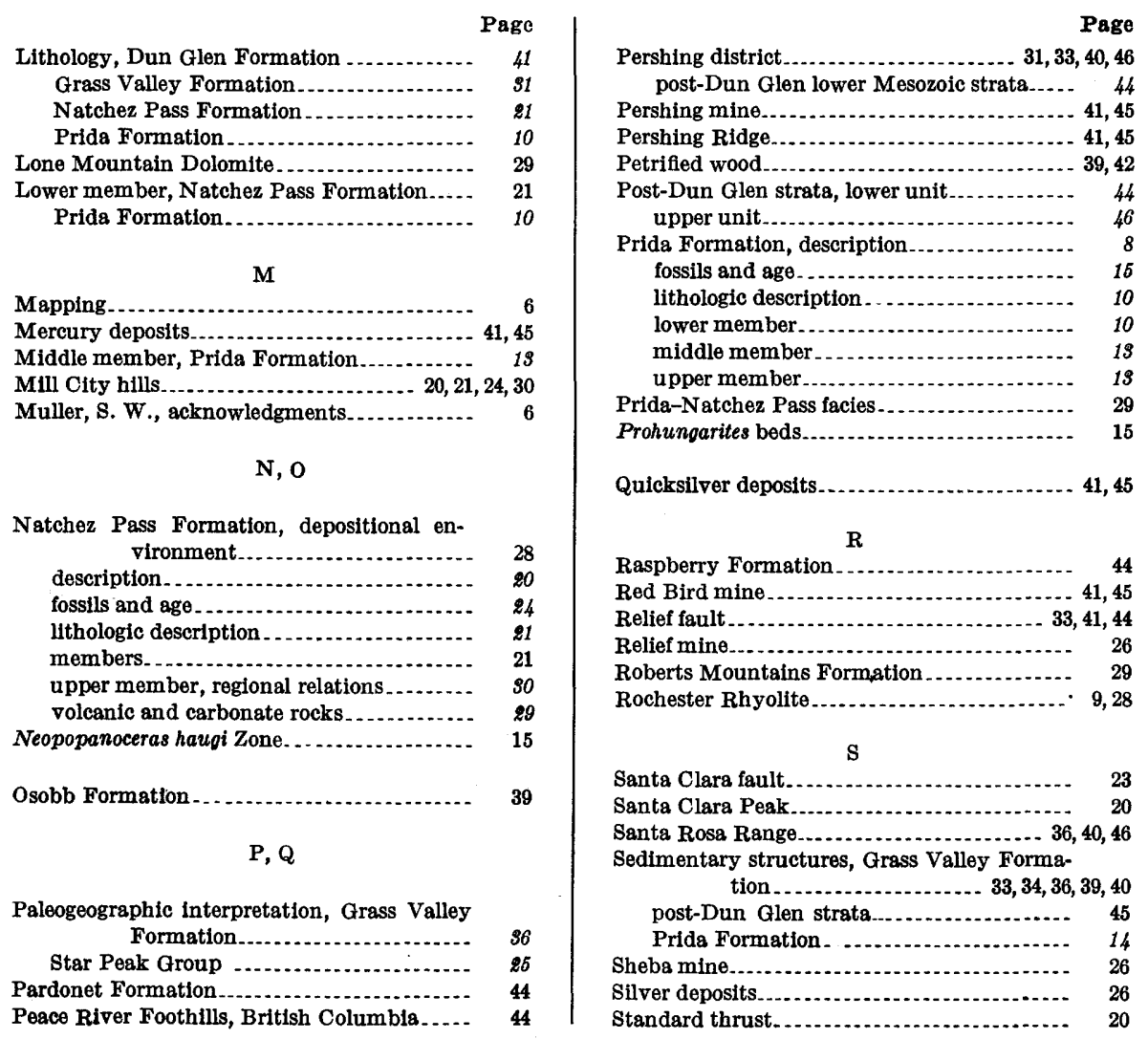

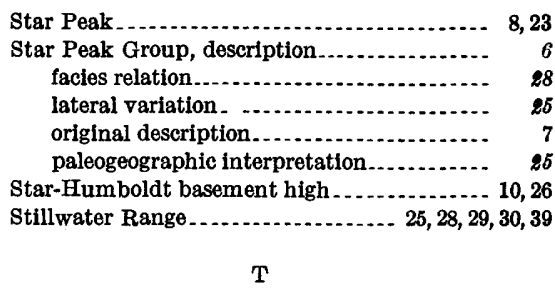

Tehama reverse fault

Tobin Formation

15

Tobin Range $\ldots . . . \ldots \ldots \ldots \ldots \ldots \ldots . . . .25,28,29,30,36,39$

Tozer, E. T., acknowledgments............. 6

Unconform'ty, Prida-Koipato............. 9

Unionville quadrangle........................

Upper member, Natchez Pass Formation..... 21, 23

Prida Formation.................

Victorio Peak Limestone

Volcanic and carbonate rocks, Natchez Pass Formation, relationship..........

Volcanic rocks, Natchez Pass Formation

Prida Formation, lower member. upper member.

Weaver Rhyolite........

West Humboldt Range.

Wheeler mine ................................. 26

Winnemucca Formation.................... 44,46

Winnemucca sequence 
